\title{
Archaeological Investigations in Alamo Plaza, San Antonio, Bexar County, Texas, 1988 and 1989
}

Anne A. Fox

Center for Archaeological Research

Follow this and additional works at: https://scholarworks.sfasu.edu/ita

Part of the American Material Culture Commons, Archaeological Anthropology Commons, Environmental Studies Commons, Other American Studies Commons, Other Arts and Humanities Commons, Other History of Art, Architecture, and Archaeology Commons, and the United States History Commons

Tell us how this article helped you.

This Article is brought to you for free and open access by the Center for Regional Heritage Research at SFA ScholarWorks. It has been accepted for inclusion in Index of Texas Archaeology: Open Access Gray Literature from the Lone Star State by an authorized editor of SFA ScholarWorks. For more information, please contact cdsscholarworks@sfasu.edu. 
Archaeological Investigations in Alamo Plaza, San Antonio, Bexar County, Texas, 1988 and 1989

\section{Creative Commons License}

(c) (1) (2)

This work is licensed under a Creative Commons Attribution-NonCommercial 4.0 International License 
ARCHAEOLOGICAL INVESTIGATIONS IN

$A L A M O \quad P L A Z A$

SAN ANTONIO, BEXAR COUNTY, TEXAS

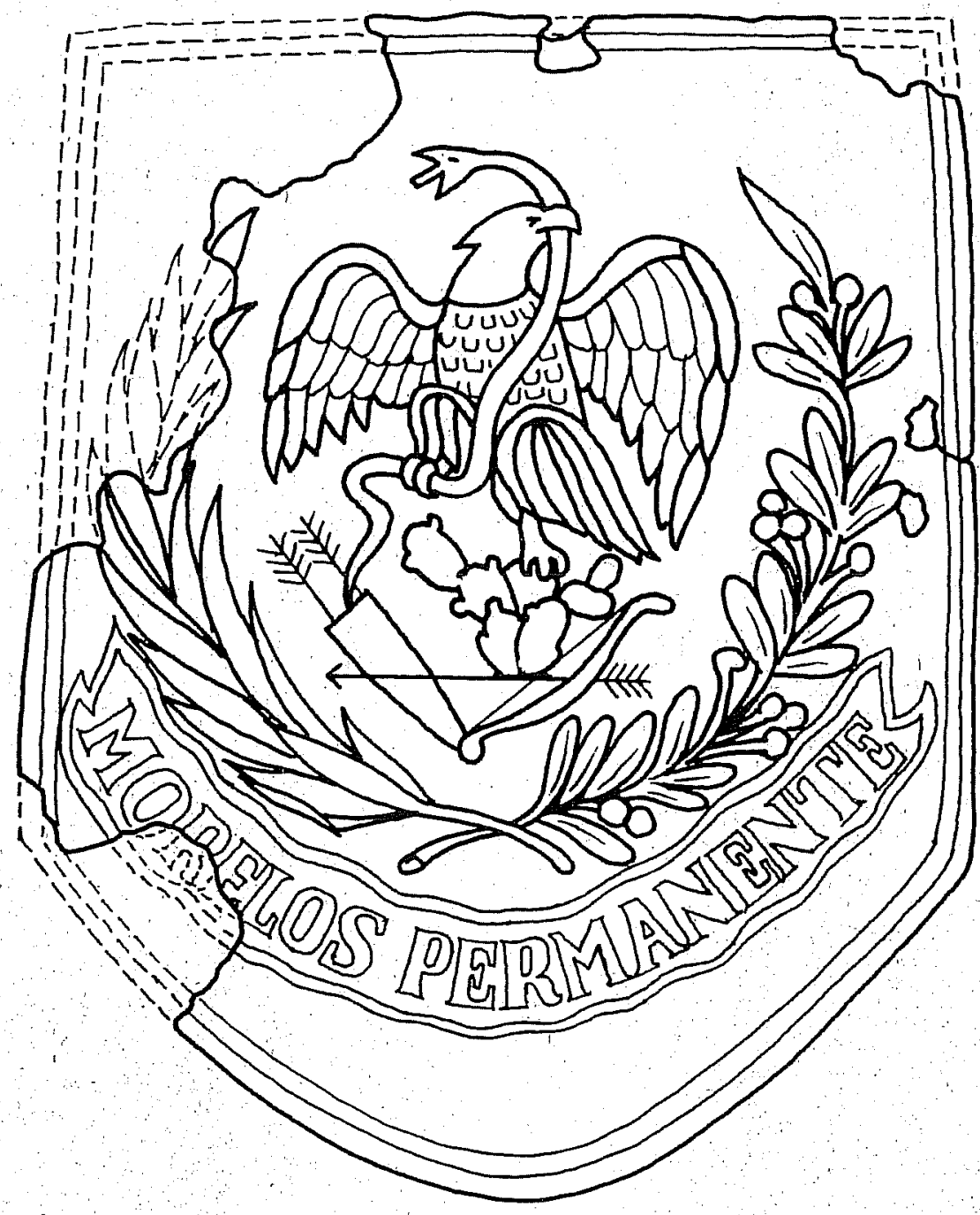

1988 AND 1989

Anne A. Fox

With Contributions by Susan W. Dial Samuel Nesmith, and Herbert G. Uecker

Center for Archaeological Research The University of Texas at San Antonio Archaeological Survey Report, No. 205 



\title{
ARCHAEOLOGICAL INVESTIGATIONS IN ALAMO PLAZA, SAN ANTONIO, BEXAR COUNTY, TEXAS, 1988 AND 1989
}

Anne A. Fox

\author{
With Contributions by \\ Susan W. Dial, \\ Samuel Nesmith, and \\ Herbert G. Uecker
}

Texas Antiquities Committee Permit Nos. 704 and 799

Center for Archaeological Research The University of Texas at San Antonio(i)

Archaeological Survey Report, No. 205 
The following information is provided in accordance with the General Rules of Practice and Procedure, Chapter 41.11 (Investigative Reports), Texas Antiquities Committee:

1. Type of investigation: excavation;

2. Project name: Alamo Plaza (41 BX 6);

3. County: Bexar;

4. Principal investigator: Jack D. Eaton;

5. Name and location of sponsoring agency: City of San Antonio, Department of Parks and Recreation, P.O. Box 839966, San Antonio, Texas 78283-3966;

6. Texas Antiquities Committee Permits No. 704 (1988) and 799 (1989);

7. Published by the Center for Archaeological Research, The University of Texas at San Antonio, San Antonio, Texas 78249-0658, 1992.

A list of publications offered by the Center for Archaeological Research can be obtained by sending $\$ 1.00$ to the Center for Archaeological Research, The University of Texas at San Antonio, San Antonio, Texas 78249-0658. 


\begin{abstract}
In June of 1988 and 1989, The University of Texas at San Antonio conducted an archaeological field school at the northern end of the plaza in front of the Alamo in downtown San Antonio. The Center for Archaeological Research cooperated with the university in organizing and staffing this field school. Excavations were limited to specific areas related to the fortifications around the main entrance to the Alamo constructed in 1835 and demolished and backfilled less than a year afterward. These fortifications consisted of a lunette and related defensive trench around the main gate, a secondary trench parallel to the south wall of the site, and a palisade wall between the church and the barracks building. The trenches were located and mapped and their contents recovered and analyzed. While important information was recovered about the construction of the fortifications, equally important is the collection of artifacts used for fill in the trenches, which represents mission and local inhabitants' depositions in the area from ca. 1750 to 1836.
\end{abstract}




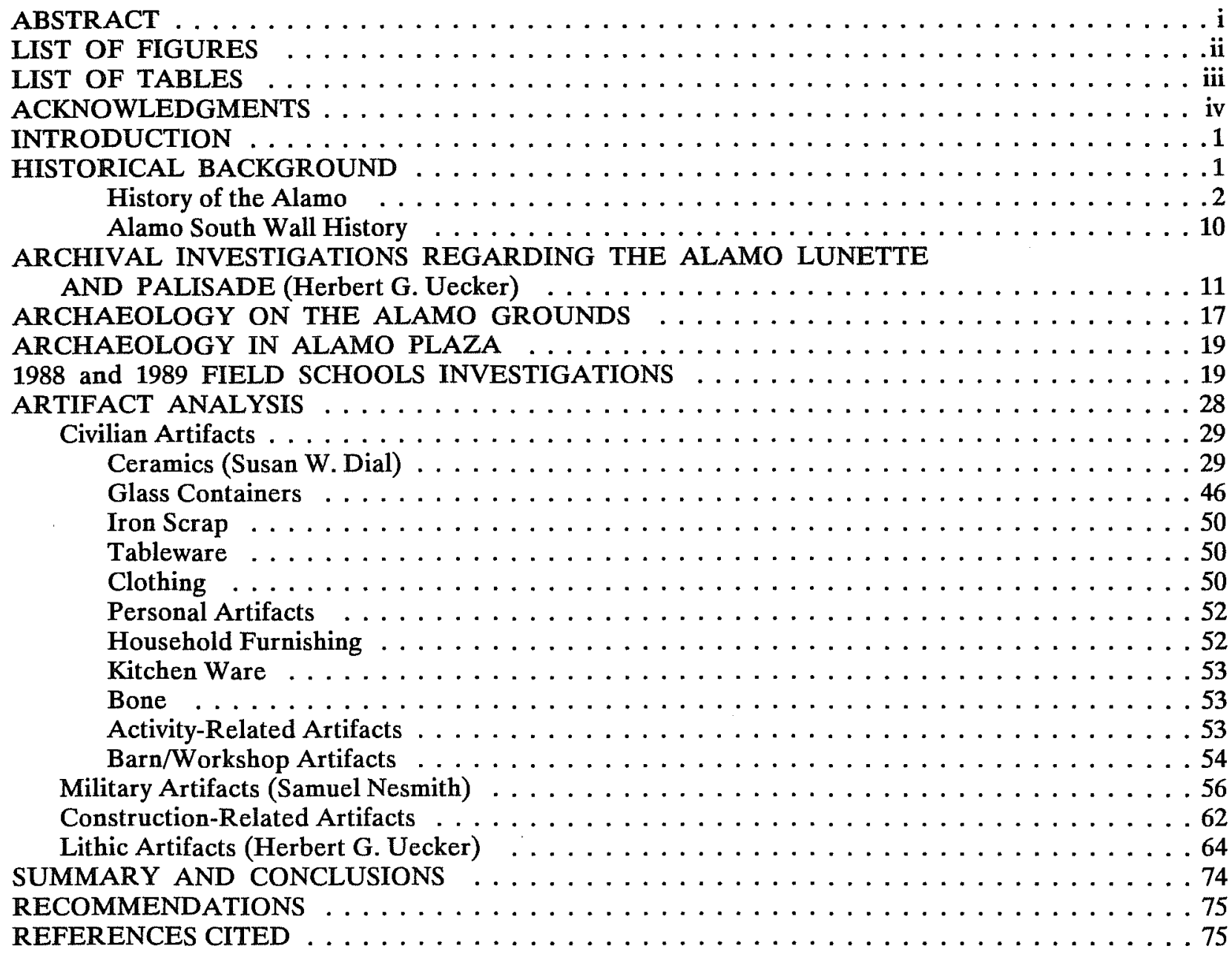

\section{LIST OF FIGURES}

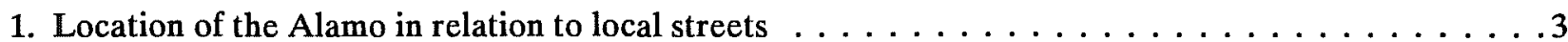

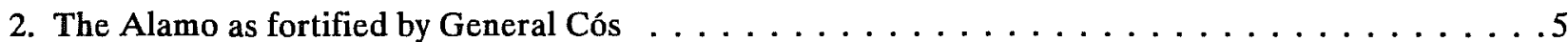

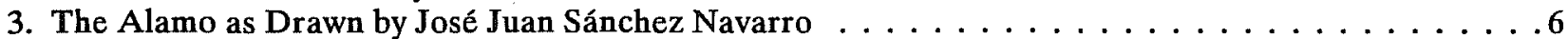

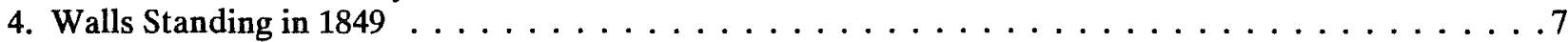

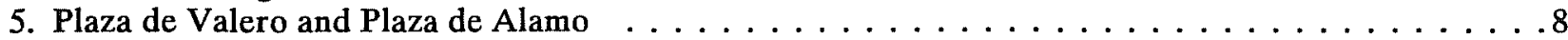

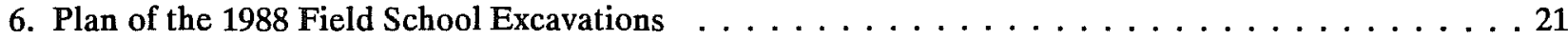

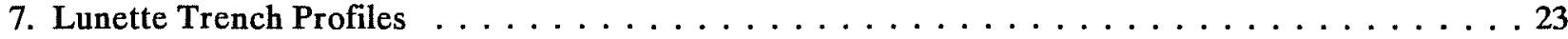

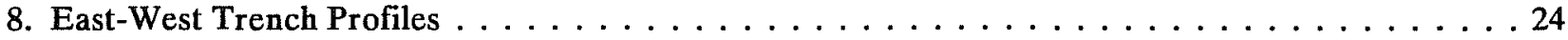

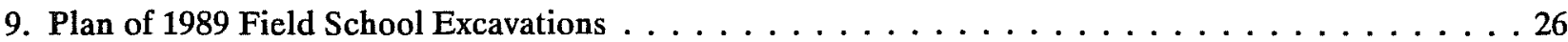

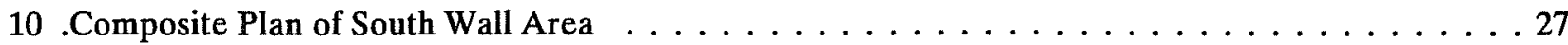

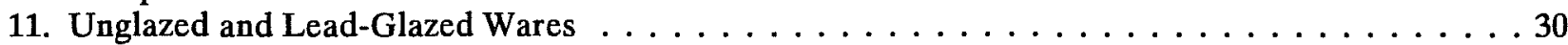

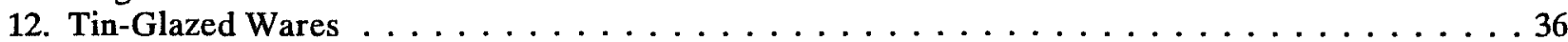

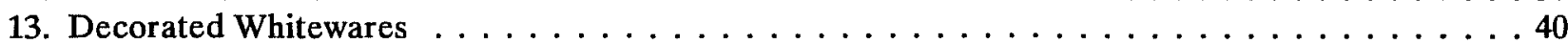

14. Hand Painted Ware . . . . . . . . . . . . . . . . . . . . . . 42

15. Transfer-Printed Wares and Maker's Marks $\ldots \ldots \ldots \ldots \ldots \ldots \ldots \ldots$

16. Glass Containers . . . . . . . . . . . . . . . . . . . . . . . . . . . . . .499

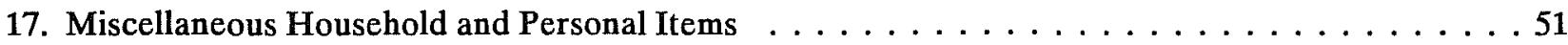

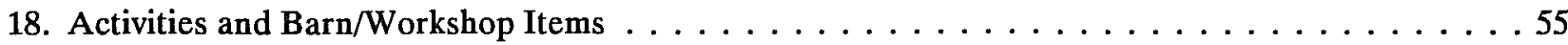

19. Arms and Military Equipment. . . . . . . . . . . . . . . . . . . . . . 59 


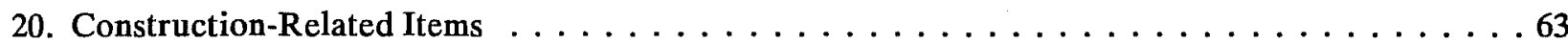

21. Selected Chipped Stone Artifacts . . . . . . . . . . . . . . . . . . . . 73

\section{LIST OF TABLES}

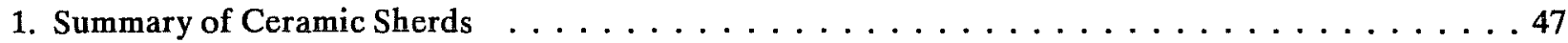

2. Ceramic Comparisons According to Origin $\ldots \ldots \ldots \ldots \ldots \ldots \ldots \ldots \ldots \ldots \ldots \ldots \ldots \ldots$

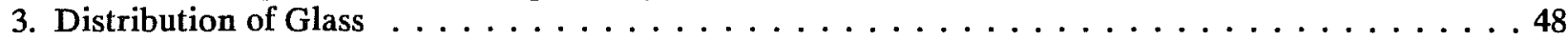

4. Total Number of Bone Fragments Recovered $\ldots \ldots \ldots \ldots \ldots \ldots \ldots \ldots \ldots$

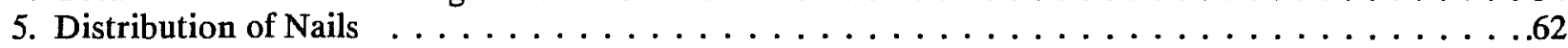

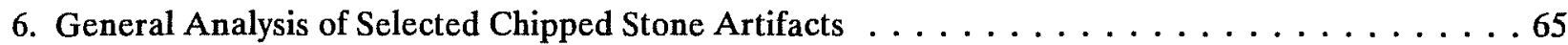

7. Flake Comparisons . . . . . . . . . . . . . . . . . . . .66 


\section{ACKNOWLEDGMENTS}

Projects of this scope require the help and cooperation of all sorts of people and organizations - so many that it is nearly impossible to mention them all. First and foremost, of course, is the San Antonio Parks and Recreation Department, which administers the Alamo Plaza. In particular, we thank Ron Darner, Dale Bransford, and Dean Fickenscher who patiently helped set up the two field school sites, gave various permissions necessary, made the numerous decisions and arrangements, and finally waited what must have seemed an unconscionably long time for the completion of this publication. We sincerely hope they find the end result is worth the effort.

No project can proceed without funding, and for this we thank the Alamo Foundation, and in particular Nancy Miller and Robert Benavides of that group. San Antonio Historic Preservation Officer, Pat Osborne, was an interested and enthusiastic bystander throughout the two-year project.

Historical research for the project was greatly aided by Dora Guerra of the Special Collections Department of the John Peace Library at UTSA, staff members at the Daughters of the Republic of Texas Library at the Alamo, and the research library at the Institute of Texan Cultures. In addition, Richard Garay shared a number of maps from his collection.

Mark Matthews, Ralph Lay, and Dave Lyons of the San Antonio Living History Association volunteered many hours to demonstrate period costumes and equipment, and answer questions of the visitors to the site during both seasons. Their help was particularly valuable in that they in this way allowed students and instructors to concentrate on the work at hand.

The following members of the Southern Texas Archaeological Association volunteered hours of their time to work alongside the students during the 1988 field school, contributing their expertise to the training aspect of the course:

\author{
Darla Cox \\ Waynne Cox \\ Don McEwan
}

Paul Maslyk

Shirley Mock

Burnley (Duke) Smith
Tommy Tomesal

Albert Uecker

Shirley Vander Veer

Tommy Tomesal, in addition, contributed many hours in scanning the backdirt from the screens with a metal detector to recover small metal objects such as musket balls that may have been missed by the screeners. Henry C. Harrell, a student participant, recorded the entire 1988 field school on video tape.

Last, but far from least, the authors wish to thank Dr. Fred Valdez and Dr. Joel Gunn for accepting the responsibility of organizing and running the 1988 and 1989 field schools, respectively, and the numerous students who persevered despite broken water pipes, rainstorms, and errant sprinklers, and contributed to the ongoing research into the history of the Alamo. 


\section{INTRODUCTION}

The Alamo (41 BX 6) is designated a State Archeological Landmark and is listed on the National Register of Historic Places. Texas Antiquities Committee permits were therefore issued for work on the site, and all excavations and ensuing research, analysis and reporting have been done in such as way as to comply with Section 106 of the National Historic Preservation Act of 1966, as amended, and its implementing regulations.

Perhaps best known as the site of an important battle in Texas history, the Alamo was originally built as a Spanish mission and therefore contains traces of Spanish, Mexican, and Anglo American occupation in varying degrees. Although the battle in $\mathbf{1 8 3 6}$ is the most widely publicized aspect of its history, relatively little archaeological investigation has been done to recover details of the fortifications created there in advance of the battle.

In 1988, the Center for Archaeological Research (CAR) was approached by the Division of Behavioral and Cultural Sciences at The University of Texas at San Antonio (UTSA) about the possibility of conducting a historic site field school at the Alamo. With the excellent help of the Parks and Recreation Department of the City of San Antonio, Dr. Fred Valdez (UTSA) and the author cooperated in planning and carrying out a six-week field school. Work was concentrated in the area immediately south of the main gate of the mission, which had been fortified by General Cós in late 1835 (see history section). Previous archaeology in this general area in 1975 (Fox, Bass, and Hester 1976) had recorded the north end of the fortification trench for the lunette around the gate. The intent of the field school, in addition to training archaeological students, was to trace the extent of this feature as far as possible within the park toward the south. Jack D. Eaton, acting director of the CAR, and the author were designated co-principal investigators and Dr. Valdez was the Field Director and instructor of the course. Texas Antiquities Committee Permit Number 704 was issued to this project.

In 1989, UTSA was approached by the Parks and Recreation Department about the possibility of conducting another similar field school in the plaza park. It was decided that Dr. Joel Gunn (UTSA) and the author would cooperate in a similar manner as was done the year before. This time the area chosen for investigations was just to the east of the park in the edge of the street that currently runs between the church and the site of the barracks on the south wall. Again a Texas Antiquities
Committee Permit was issued (No. 799), and the work was conducted under the same general plan as that of the year before with Dr. Gunn acting as the course instructor.

When the field work portion of the project was completed, students processed the artifacts in the CAR laboratory, and several students then wrote special studies in connection with the history and archaeology of the project. Herbert Uecker carried out additional research into the history of fortification and his paper is included in this report. Clinton McKenzie (1989) wrote a much-needed analysis of Guanajuato ware, a particular type of 19th century tin-glazed earthenware, which has been useful in this study. Susan Dial, a graduate student at the University of Texas at Austin, undertook the description and analysis of the ceramics recovered during the 1988 field school for a research paper for Dr. James Neely of that institution. She has generously allowed the author to use her paper as the basis for the ceramics section of this report, since the ceramics recovered during the following season were the same assortment. A minimal amount of change in total numbers and a few editorial adjustments are all that have been necessary to fit her paper into this report. Sam Nesmith, local expert on military uniforms and equipment, has contributed his considerable expertise in the identification and description of all the military-related materials recovered from both field schools. A paper by Hugh Robichaux (1989) was helpful in providing possible explanations for the soil formations found by the 1989 excavations.

All materials recovered from the field schools and all field notes, artifact catalogs, and research notes are curated at the laboratory of the CAR. Funding for both projects was administered by the Alamo Foundation.

\section{HISTORICAL BACKGROUND}

In order to fully understand and appreciate the importance of this project's findings, it is necessary to review the history of the Alamo as a whole. For a detailed treatment, the reader is urged to consult the account of the 1975 excavations (Fox, Bass and Hester 1976:2-31) and a history written by Mardith Schuetz (1966) in connection with excavations done that year on the Alamo grounds. A complete history of the founding, operation, and secularization of the mission can be found in Fr. Marion Habig's (1968:29-77) book, The Alamo Chain of Missions. Probably the most accurate 
description of the Battle of the Alamo in 1836 is found in Walter Lord's (1961), A Time to Stand.

\section{HISTORY OF THE ALAMO}

The first official settlement of San Antonio in 1718 was located on either side of San Pedro Creek just south of the springs (Habig 1968:29). The settlement consisted of a group of civilians, a detachment of presidial soldiers, and the temporary chapel of Mission San Antonio de Valero (ibid.:38). In the summer of 1719 the mission was moved to the east side of the river to a location somewhat south of the present site. There the missionaries built a stone tower and a group of small huts. Then in 1724 a hurricane caused such destruction at the second site that the mission was moved to its present location (Ramsdell 1959:16-17).

By 1745 the new mission site included a large adobe hall used as a church, and a convent for the missionaries. A new stone church was under construction. An acequia carried water to the mission for irrigation and domestic uses, from a point near the headsprings of the San Antonio River. The Indians lived in two rows of adobe huts that stood on either side of a branch of the acequia that ran through the mission plaza (Habig 1968:50). A wall surrounded the entire mission (Bolton 1970:20)

After an inspection of the mission in 1762, Fr. Mariano Francisco de los Dolores reported that the plaza was surrounded by a wall and that there was a defensive tower with loopholes over the gate in the south wall (Fox, Bass, and Hester 1976:4). At some point in mid-century the Indian quarters that had been in the center of the plaza were moved back against the walls, and by 1772 most of them had arcaded porches or corridors in front of them. A description of the mission plaza by Fr. Jose Francisco Lopez in 1789 gives us the following picture (Habig 1968:64):

It is built to form almost a square, surrounded by a single stone and mud wall. . . The same rampart serves as a wall for most of the fifteen or sixteen houses, with ample capacity for lodging the Indians.

In 1793, Mission San Antonio de Valero was secularized, and the mission and surrounding lands were apportioned to the remaining mission Indians and to a group of displaced settlers from Los Adaes in east Texas. An inventory done at that time mentioned that the main gate in the south wall was five varas (13.8 feet) wide and four varas (11 feet) high (Castaneda 1942:44; Schuetz 1966:33).

At the time of secularization, a number of families were living in the houses built for the Indians along the west side of the plaza. At the southwest corner lived the family of Pedro de los Angeles Charle. A house and carpenter's shop with their respective lots of land had been given to citizen Charle by Fr. Lopez in 1786 as a reward for his years of faithful service to the mission as carpenter, barber, and sacristan. By 1793 Charle had died and left the property to his wife, Maria de Estrada (BCDR Vol. G1:1-3). Ownership of the church and convento apparently remained in the hands of the Catholic Church.

When France failed to regain possession of the Louisiana territory in the early 1800 s, immediate action was taken by the Spanish to strengthen the province's defenses. On December 29, 1802, the mobile company of San Carlos de Parras del Alamo was assigned to San Antonio. They moved into the unoccupied buildings still standing around the plaza at Mission Valero. Barracks (today called the Low Barracks) were built at this time against the south wall and inside the plaza to house these troops (Smith 1966:8). It is believed that the mission came to be called The Alamo in reference to the name of this company. Soldiers with their families moved into the area south of the mission plaza, joining the small group of mission-related civilians such as the Charle family, to form a settlement that came to be called the Pueblo of Valero. Apparently this settlement extended several blocks south to include the area later to be called La Villita (Fretelliere 1912:58; see also Fig. 1).

In 1805 , a military hospital was established in some of the old mission buildings. Descriptions of various improvements and remodelings of this hospital and its related facilities over the next few years suggest that it was located in the south end of the convento building (Nixon 1936:17, 27-28).

The Alamo then came to play a part in various uprisings related to the battle for independence from Spain and the founding of the Mexican Republic in 1821 (Garrett 1968:178; Yoakum 1855:168). An influx of additional troops at this time caused housing problems at the Alamo for which various solutions were discussed but apparently little was done. In 1825, the commander of the Alamo Garrison requested that he be allowed to quarter troops in the old convento buildings. Apparently this request was eventually granted, due to the intervention of the Captain General of the Interior Provinces, Anastasio Bustamante 


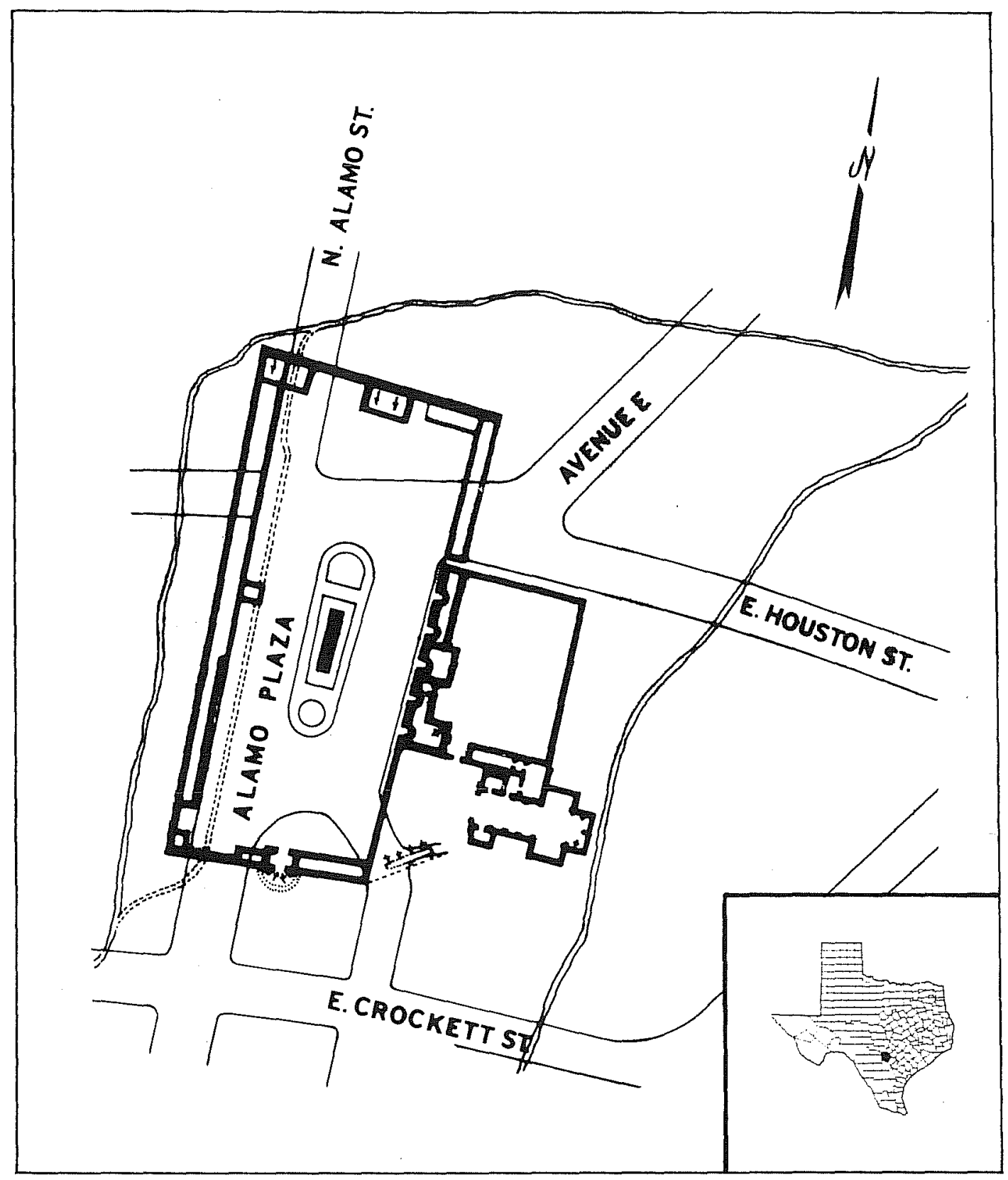

Figure 1. Location of The Alamo in Relation to Local Streets. (Fox, Bass, and Hester 1976:Figure 2) 
(Castaneda 1950:349). By 1829 there were more than 300 people living in the Alamo community east of the river. Ownership of the church and convento remained in the hands of the Catholic church.

When General Martín Perfecto de Cós marched into San Antonio in 1835, his troops occupied the Alamo and set about fortifying the site, mounting cannon in various locations (Fox, Bass, and Hester 1976:10-11). A part of this effort was the construction of a cedar palisade between the southwest corner of the church and the Low Barracks against the south wall. Tradition states that this was built by digging an eight-foot-deep trench behind which were set two rows of posts six feet apart. The dirt from the trench was used to fill the space between the posts, creating a palisaded fortification wall (Chabot 1941:24). Cós also evidently rerouted the acequia outside the west wall of the plaza at this time (James Ivey, personal communication).

After the Texan army defeated Cós, the remaining Texans occupied the Alamo. The commander of the army, Sam Houston, felt that the site was not defensible and ordered it destroyed. There were not sufficient teams available to carry away the artillery, however, and the decision was made to remain and take a stand at San Antonio against the certain retaliation approaching from Mexico (Yoakum 1855:58).

Although there were plans for fortifying the Alamo, apparently there was insufficient military organization among the group present to carry out more than the most basic efforts (Chabot 1941:33). Castaneda (1950:288) describes the fort at the time of the 1836 battle:

... From the northeast corner of the church a wall ran 186 feet north and 102 feet west to join the long barracks and thus form a patio and inner court. A strong stockade had been built from the southwest corner of the chapel to the low barracks, a one story building, 114 by 17 feet, which comprised part of the south wall. Half the building was used as a prison and the remainder as soldiers quarters. Other low buildings formed part of the west wall. The enclosure to the west of the chapel formed a quadrangle 154 by 54 feet. The north wall was somewhat longer than the south wall.

A ramp and gun emplacement for an 18-pound cannon were constructed on the southwest corner.
The south gate was fortified with trenching and gun emplacements (Figs. 2 and 3).

The ensuing siege badly damaged the walls and buildings, leaving most of the plaza area in ruins. Additional havoc was created soon thereafter by General Andrade, under orders of General Filisola to demolish all fortifications and render them useless (Castaneda 1928:202). Andrade had as many walls as possible knocked down, and the fortification trenches were filled with the rubble.

The Alamo was deserted and unclaimed from 1836 until 1841, when the Texas Congress declared it to be the property of the Catholic church. A sketch of the Alamo by English traveler William Bollaert in 1843 (Schoelwer with Glaser 1985:33) shows the general appearance of the Low Barracks and gate at that time. By 1840 the plaza had been reduced to "nothing more than the convent, some old broken down walls, and ruins"(Rodriguez 1913).

With the annexation of Texas and the start of the Mexican war, the United States Army arrived in Texas. A plan drawn by Edward Everett in 1846 showed the existing parts of the complex that were still standing (Fig. 4). Apparently at least a few of the Indian quarters buildings on the west wall were still sound enough to be in use, according to a sketch of the area done at that time by Seth Eastman (Schoelwer with Glaser 1985:31) that shows a number of structures in various stages of decay.

In 1849, Pedro Charle's daughter Concepción, in her eighties, and her son and son-in-law shared ownership of the original grant made in 1768 ( $B C D R$ Vol. H1:503). The original family home, demolished for the mounting of a cannon in 1835-1836, had been rebuilt, and a stone house stood where Pedro Charle's carpenter shop had been, south of the corner.

Also by 1849 (Fig. 5), San Antonio had been chosen headquarters of the Eighth Military District, and the Alamo became the quartermaster depot. The plaza came into heavy use as a staging area for more than 100 army wagons and teams daily carrying military supplies coming in from Indianola and going out to the frontier posts. There were also civilian contract wagons and Mexican carts involved in this traffic (Babbitt 1849).

The Army cleaned out and roofed the church and installed a second floor to use for storage of supplies. The Low Barracks against the south wall were repaired and put to use, as judged from Captain Arthur T. Lee's painting of 1849 (Thomas 1970:43). Apparently the convento was not used by the Army until after 1850 (Fox, Bass, and Hester 1976:17). By 1853, the entire convento and church 


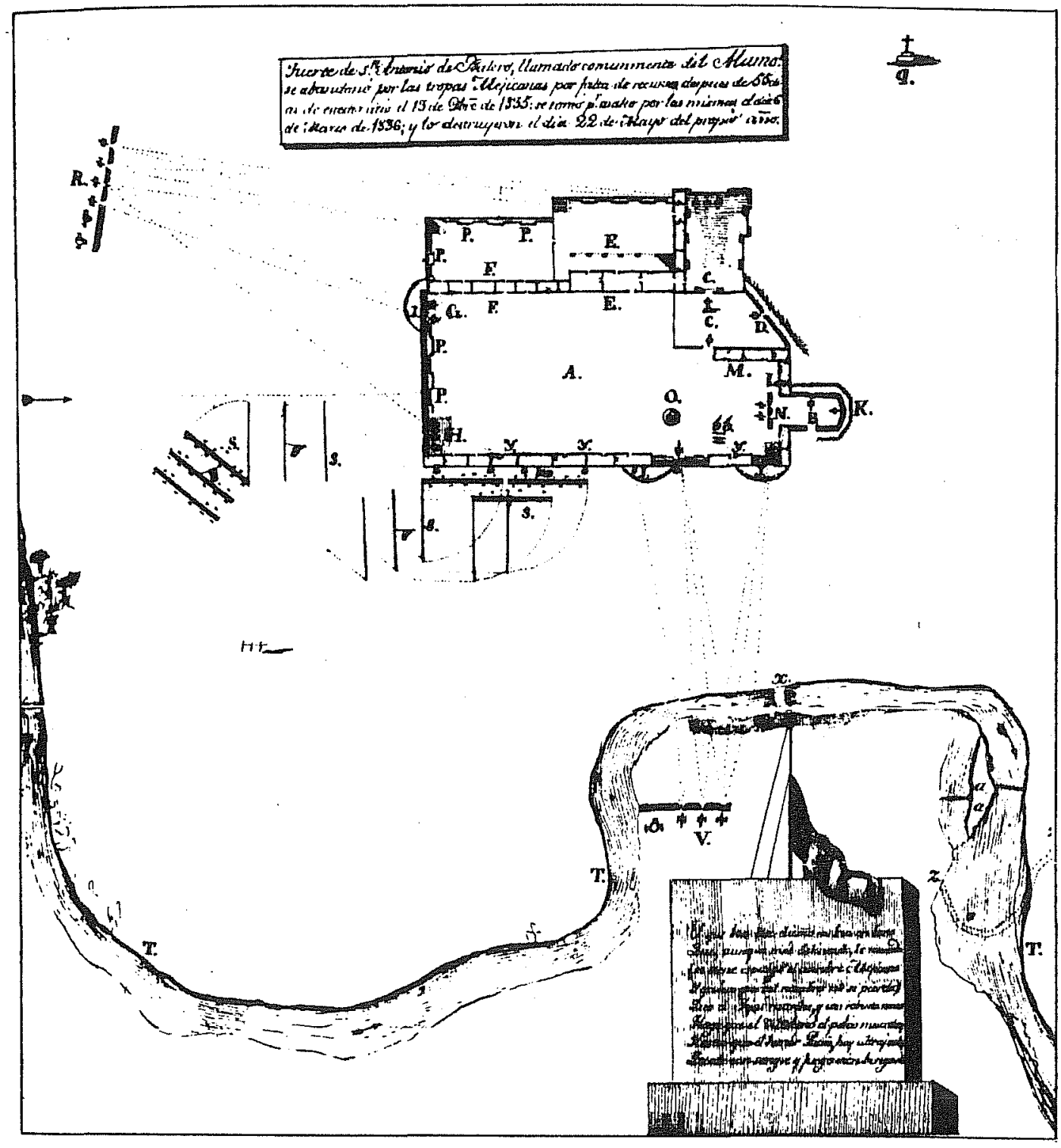

Figure 3. The Alamo as Drawn by José Juan Sánchez Navarro. Drawn in 1836 by José Juan Sánchez Navarro, Adjutant Inspector of the Departments of Nuevo León and Tamaulipas (Schoelwer 1985:71). 


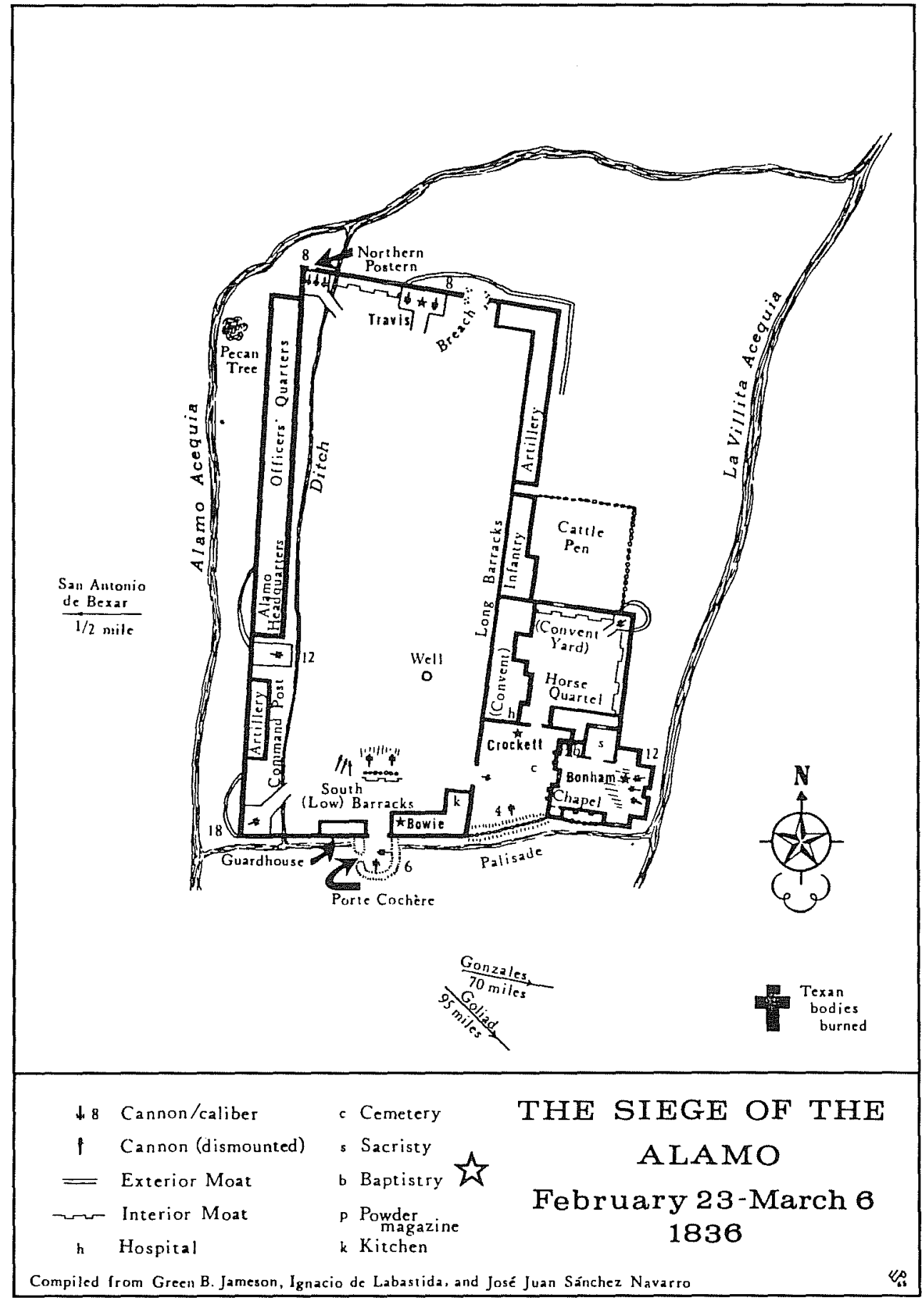

Figure 2. The Alamo as Fortified by Gen. Coś. Drawn by Col. Yanacio de Labastida for Gen. Santa Anna (Schowiwer 1985:72). 

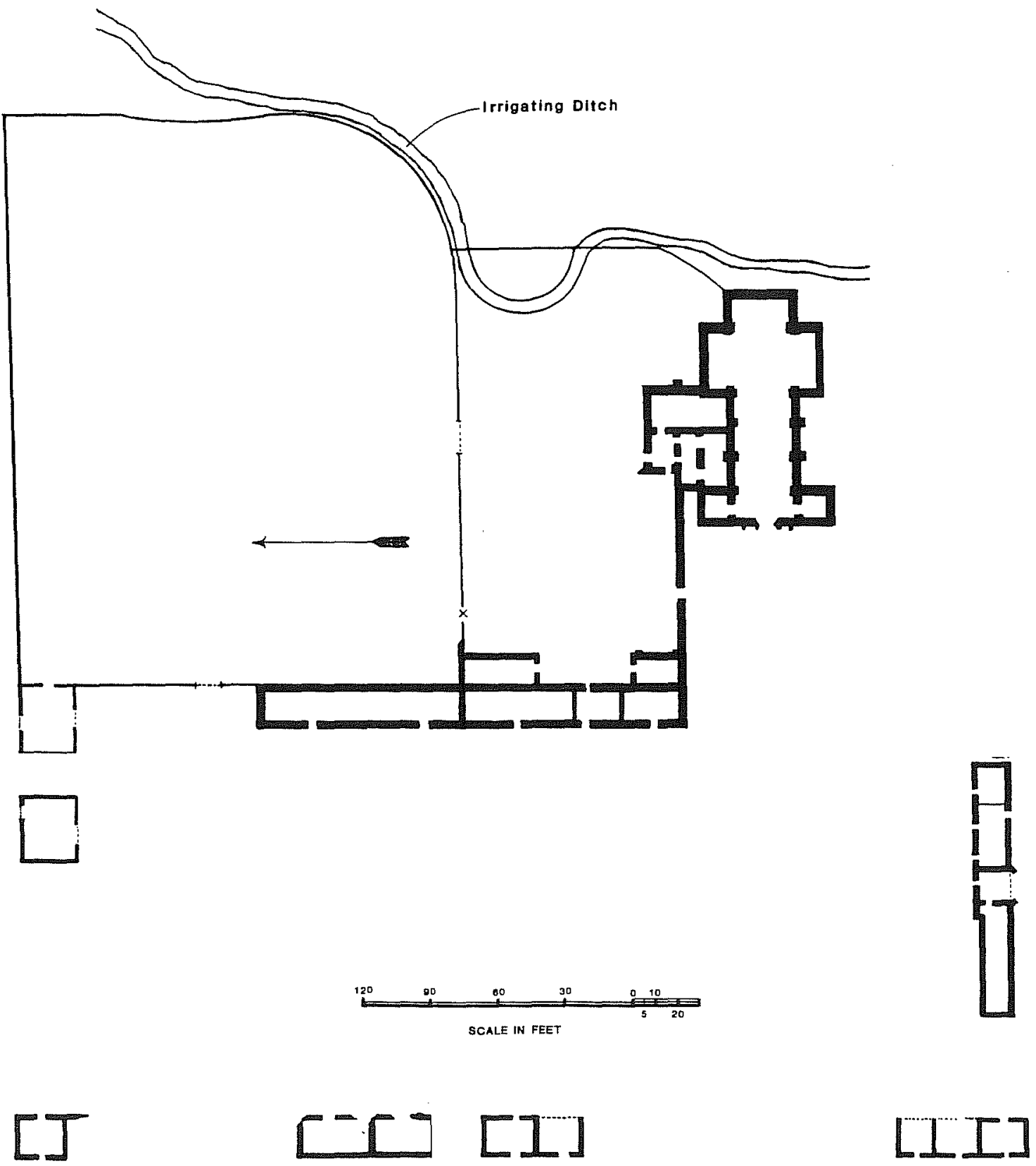

Figure 4. Walls Standing in 1849. Taken from map drawn by Lt. Edward Everett (Fox, Bass, and Hester 1976:Figure 4). 


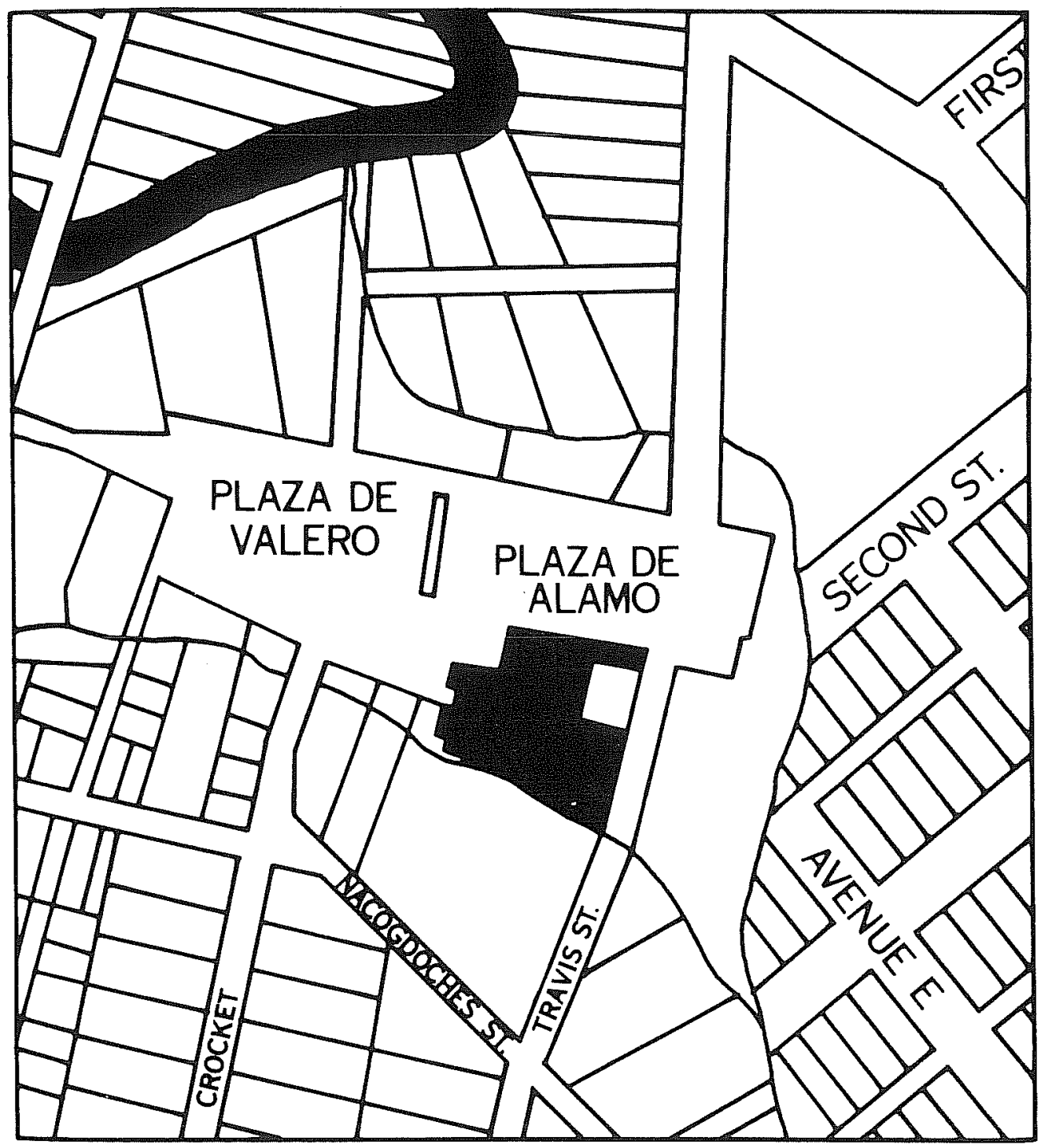

Figure 5. The Plazas in 1868. Copy of a section of a City of San Antonio map located the National Archives Records of the War Department, Headquarters of the Army, Descriptive Book of The District of Texas, July 1, 1868, No 220, Map No. 5. 
complex had been renovated and were in use as "workshops, stables, storehouses, rooms, and offices" (Freeman 1853). Private ownership of the west wall appears not to have been challenged. Samuel Maverick had acquired most of the land at the north end of the plaza and north and east of the convento, and was leasing some of this to the Army. He also was building his private residence adjacent to the northwest corner of the plaza (Fox, Bass, and Hester 1976:18).

As the area developed, it became one large plaza, divided across the center by the old barracks building (Fig. 5) and including both the interior Plaza of the Alamo and an area of equal size to the south which came to be called the Plaza of Valero. In 1855, William Menger built a house and brewery facing west onto the Plaza of Valero, to the south of the Alamo church. Then in 1859 , he built a hotel to accommodate the increasing traffic in the Alamo Plaza area (San Antonio Light 1959; Newcomb 1926:73).

About this time small houses began to be built along the west wall occupied by soldiers and their families and by small shops to serve the growing local population. In 1859 , a meat market was built on the Plaza of Valero, just south of the Low Barracks building then in use by the Army (Smith 1966:49; Freeman 1972:3).

After a temporary lull during the Civil War, more activity began to center around the plaza in 1865. The city became aware of the need to clean up the area, to provide proper drainage, and to remove eyesores such as the old barracks building which by this time had fallen into ruin again (Fox, Bass, and Hester 1976:21-22). By the late 1870s, the barracks building had been removed, and the area was a booming commercial and transportation center. When the Army moved into its new home at Fort Sam Houston, Honore Grenet, a French businessman, acquired the convento building (BCDR Vol. 7:213) and remodeled it into a fancy, two-story emporium selling all sorts of household goods, including wine and liquor. The Alamo church was used as a storehouse (Corner 1890:11).

In June 1878, the City of San Antonio began operation of a street railway with a terminal at the market building on the plaza (Newcomb 1926:97). A new building at the south end of the plaza soon housed the United States Post Office. However, despite the new buildings and new interest in Alamo Plaza, the clean-up job was not completed until the market building was removed from the plaza in 1882 (Freeman 1972:7).

By 1886, a new Grand Opera House (Smith 1966:39) stood just south of the spot where the
Charle family home had been a hundred years before. The Grenet store (which had incorporated the walls of the old convento) was sold to the Hugo and Schmeltzer Company in the same year, paving the way for its eventual abandonment.

Alamo Plaza in 1891 was a greatly changed place from what it had been at mid-century. The streets were paved with mesquite blocks, and there were sidewalks all around the plaza. A park with a handsome bandstand occupied the center of the plaza, which was planted with shrubs, trees, and flowering plants. The businesses around the plaza had undergone a complete change in emphasis. Where there had been transportation and shipping-oriented businesses such as stables, feed stores, and transfer companies, now there were clothing stores, restaurants, saloons, and amusement halls (Smith 1966:59). The post office had been moved to a new building at the north end of the plaza, astride the original north wall of the mission plaza.

Apparently by 1893 local interest had started building to restore the Alamo. The State had acquired the church building from the Catholic church in 1883. The City condemned the Hugo and Schmeltzer property in 1889 , clearing off the additions built by Grenet and later alterations by Hugo and Schmeltzer. This cleared the way for the purchase of the property by the Daughters of the Republic of Texas (DRT) in 1904, and the assumption of the site by the State the following year. After considerable disagreement among various factions of the DRT and state officials, in 1915, the restoration began which would bring the Alamo buildings to their present form (Chabot 1941:52-54).

Meanwhile the plaza was developing, as it always had, in response to local needs and pressures. Asphalt topping was laid over the mesquite block paving in the streets, and the old bandstand was replaced with a new concrete structure with public restrooms below ground. The park in the center of the plaza was enlarged and redesigned, and Crockett Street was cut through the center. The area in front of the church was widened and landscaped in 1934, and the cenotaph was commissioned and installed in 1940 (Fox, Bass, and Hester 1976:26). Total historic emphasis during this period was on the church and convento buildings as representing the Alamo, and little if any recognition was given to the fact that the site had once been Mission San Antonio de Valero, or that the plaza should be considered every bit as historic as the standing structures. 
It was not until 1975 and the approach of the State's bicentennial celebration, that attention was again called to Alamo Plaza. The City drew up plans to redesign the park area, reemphasizing the totality of the plaza by again cutting off Crockett Street, and paving much of the original Alamo Plaza with flagstone. As part of the new park design, a copy of the original bandstand replaced the one built in the $1930 \mathrm{~s}$, and the outline of the Low Barracks building was constructed above ground as a large, stone-edged planter box across the park.

This renovation sparked additional efforts at restoration of the original plaza boundaries. In the ensuing years, the buildings that covered the location of the southwest corner of the plaza have been removed. The area has been restored to show a semblance of the mission period wall lines in connection with the construction of a park linking Alamo Plaza with the river. This has led to the restoration and reuse of a number of late 19th-century buildings on the west side of the plaza and a general rejuvenation of the entire plaza. A new effort is now being made to bring shoppers and tourists into the area and to encourage a new understanding of the total extent of the historic site.

\section{ALAMO SOUTH WALL HISTORY}

Drawn from the previous section and from Fox, Bass, and Hester (1976:2-26), the following pertinent events have been considered in the planning and interpretation of the results of the two field school excavations.

1724 Mission San Antonio de Valero was moved to its present site. Artifacts found in the vicinity should date from this time.

1745 A wall surrounded the mission. This implies that traffic to and from the site would have been restricted to an entrance gate, probably located where the road from the town entered the mission. The mission dump would have been located outside the gate.

1762 A gate in the south wall had a defensive tower. Construction necessary to support such a tower would probably account for the addition of the triangular-shaped projections on either side of the gate, noted by later map makers.

1785 Pedro Charle was granted a house and workshop at the southwest corner of the mission.
1792 Charle's widow and family were living at the mission, presumably in the same location.

1793 The gate was described as five varas (approx. 14 feet) wide.

1802 The mobile company of San Carlos de Parras del Alamo built the low barracks and prison against the south wall.

1805 A military hospital was established, necessitating repairs and remodeling of some mission structures.

1835 General Cós fortified the Alamo, building the lunette around the gate and the palisade wall between the church and the low barracks.

1836 The battles of the Alamo and San Jacinto resulted in the dismantling of the fortifications. At this time, the dirt that was dug from the various trenches was dumped back into the trenches to fill them.

1846 The only Alamo structures standing in the south gate area were the low barracks and jail which supported the gate. There was no visible evidence of the lunette or the palisade or their trenches.

1848 U.S. and Confederate armies used the Alamo as a quartermasters' depot. The low barracks was repaired for use as a granary. Wagons carrying heavy loads of military supplies and equipment drove over and parked on the surrounding ground surface, which became a swamp in wet weather.

1849 The descendants of Pedro Charle were still living at the southwest corner of the old mission plaza.

1872 The low barracks was torn down, merging the two plazas into one.

1876 The quartermaster depot was moved to Fort Sam Houston.

1889 Wood block paving was installed in the plaza, and topsoil was brought in to make a park in the center of the plaza.

1920 The park was remodeled and additional topsoil was added.

1976 The park was remodeled again. A planter was built approximately over the wall lines of the low barracks. 


\section{ARCHIVAL INVESTIGATIONS REGARDING THE ALAMO LUNETTE AND PALISADE}

\author{
By Herbert G. Uecker
}

In conjunction with the summer, 1989, excavations at the Alamo, archival research was conducted on two defensive fortification features of the south wall that date to the famous March 6, 1836 battle. These features consist of a lunette and a palisade, both of which were presumably armed with artillery pieces. Briefly, the Alamo lunette was a small, stockaded enclosure adjacent to the south gate on the outside of the main garrison (courtyard) wall. It was roughly rectangular in plan configuration with a ditch at its outer perimeter. The Alamo palisade was a partition probably composed of two parallel rows of upright timbers. The interior space between the rows would have been filled with soil dug from an adjacent outer ditch. It extended from the southwest corner of the Alamo chapel to the southeast corner of the low barracks. The barracks was located on the inside and at the east end of the south wall (See Fig. 1).

Excavations conducted near the south wall in 1976 and 1988 helped determine the exact location and size as well as the precise construction details of the lunette. Excavations near the southwest corner of the chapel in 1977 and near the location of the east end of the low barracks in 1989 produced analogous information about the palisade. The purpose of the archival research undertaken during the 1989 excavations was to determine the locations of 1836-vintage fortification structures or features prior to discovery of any extant remnants and to augment interpretations of the actual finds. The fulfillment of these goals was tempered by contractual time and budget constraints.

\section{Research Scope and Procedures}

The first phase of the archival investigations was an attempt to discover previously unknown primary accounts concerning the lunette and palisade at the Alamo. With this objective in mind, several local institutions were consulted. These included the Daughters of the Republic of Texas Research Library at the Alamo; the John Peace Library and Special Collections Department at the University of Texas at San Antonio, The Center for Archaeological Research at the University of Texas at San Antonio; and the Institute of Texan Cultures (photographic collection). Investigations at these research facilities were performed over a period of about six weeks concurrently with the summer 1989 Alamo excavations, and for an additional two weeks in early 1990. Also, in-person interviews with several knowledgeable San Antonians who are avid Alamo history buffs were conducted during that same period. In spite of these efforts, no new primary sources on the Alamo fortifications were found.

The search for obscure primary sources was then abandoned and subsequent efforts were concentrated on reconstructing from secondary sources the general historical context of the building of the lunette and palisade. Two distinct lines of investigation were pursued: (1) the history of late-18th and early-19th century military fortifications was examined; and (2) the personal backgrounds of the individuals responsible for the building and modification of the Alamo lunette and palisade were explored.

\section{Late-18th and Early-19th Century Fortifications.}

Since the history of European-style defensive fortifications dates to the time of the first medieval castles (Haythornthwaite 1979:94;Eaton 1980:8), there is a large volume of documentary information on the subject available to modern researchers. No attempt is made here to summarize this vast amount of material. The interested reader is referred to the references cited for additional data.

Guerlac (1986:64-90) has explained the rather lengthy history of the development of the principles of fortification in use during the 18th and 19th centuries. According to Guerlac, a number of significant changes in the theory and practice of European warfare occurred from about the 1600s onward. At the beginning of the cycle of changes, as the use of open field encounters increased, so did the size of armies, particularly the size of infantry components. As the effective range and accuracy of artillery gradually improved, tactics were drastically altered. Sieges, wherein a defending army retired to a heavily fortified garrison that was then attacked from the outside by the opposing army, became the norm:

The basic theory of fortification was that no army could operate or leave its lines of communication unguarded with any sizeable enemy presence in the rear. Thus a fortified city could not be bypassed without risk, particularly if its garrison were capable of sallying out; thus, enemy 
fortresses had to be 'reduced' (captured) before any lengthy advance could continue. [Haythornthwaite 1979:94].

Accordingly, the outcome of military activities became increasingly dependent upon the proper design and employment of defensive fortifications.

An elaborate and mathematically precise science of fortification had developed by the time of the Napoleonic Wars. Written treatises and field manuals had proliferated. Several publications on 18th and 19th century fortification theory were consulted in an attempt to gain some perspective on the military training and orientation of the individuals who constructed the defenses at the Alamo. The following were particularly helpful: $A$ Treatise Containing the Elementary Part of Fortification, Regular and Irregular (Muller 1746); Handbook for Active Service Containing Practical Instructions in Campaign Duties for the Use of Volunteers (Viele 1861); The Elements of Field Fortifications for the Use of the Cadets of the United States Military Academy at West Point (Wheeler 1898); and Weapons and Equipment of the Napoleonic Wars (Haythornthwaite 1979). The history of palisades and lunettes presented herein was taken primarily from these and similar works. Since the jargon of fortification theory is very technical, simplified definitions and descriptions of the features are given first, followed by a sampling of the more specialized definitions from technical field manuals.

\section{Alamo Fortifications}

Numerous archival accounts testify to the fact that the Alamo was fortified by a detachment of the Mexican army under the direction of General Martín Perfecto de Cós in mid-to-late October of 1835 , just prior to the Battle of Bexar. In spite of vigorous efforts to locate information on the details of Cós' work at the Alamo or anything about his general background or his military training, none was found. All that seems to be known about Cós, or at least that is available from local archival sources, is that he was Santa Anna's brother-in-law.

Before the alterations implemented by Cós, the Alamo had been used as a defensive shelter against Indian attacks during Spanish Colonial times. An area about three acres in size had been enclosed with stone walls for this purpose (Fox, Bass, and Hester 1976:3,6-8; see Fig. 1). These walls were still in place when the Cós party arrived, but there were several weak points and gaps in them. The largest was the opening toward the southeast corner of the compound between the low barracks and the chapel, a distance of about 110 feet. The Alamo palisade was constructed to remedy this situation.

After Cós' defeat, Green B. Jameson, a young lawyer and engineer from Kentucky who settled in Brazoria and then joined the Texan army at Gonzales, was appointed as ensign and chief engineer at Bexar. Shortly after assuming his duties, Jameson set about to repair and strengthen the fortifications at the Alamo. In a letter sent to Sam Houston at Goliad dated January 18, 1836, Jameson wrote:

I send you herewith enclosed a neat plat of the fortress exhibiting its true condition at this time, and also an index being duplicates of my former addressed to you at Washington, added to which is a recapitulation more explanatory, and showing the improvements already made by me.

You can plainly see by the plat that the Alamo was never built by a military people for a fortress; tho it is strong, there is not a redoubt that will command the whole line of the fort, all is in plain wall and intended to take advantage with a few pieces of artillery, it is a strong place and better it should remain as it is after completing the half moon batteries than to rebuild it [from Williams 1934:406-408;cf. Jenkins 1973:4, 58-60; emphasis added].

Unfortunately, the plat referred to in the letter has never been located. Williams (1934:398) intimates that the plat may have been given by Houston to the historian Henderson Yoakum while Yoakum was preparing the manuscript for History of Texas, and that it eventually was destroyed in a fire at the home of Yoakum's daughter-in-law in the city of Houston. Thus, there are apparently no extant plans of the Alamo fortifications that were made in a direct context by military personnel or any other party who was present at the Alamo prior to, or during, the battle.

Evidently the battle plans by José Sanchez Navarro (1938:96-98:Fig. 3) and Ygnacio de Labastida (Fig. 2) are the only ones made soon after the battle that have survived. Virtually all other maps and literary accounts were produced long after the battle (cf. Filisola 1849:182-185; Ford 
1875; Castaneda 1928:14-15, 100-103, 202-203; Potter 1933:2-5; Santos 1968:164; Jenkins 1973:58-61; Perry 1975:44-49; Fox, Bass, and Hester 1976:10-12, 52; Eaton 1980:8-10, 47; Schoelwer and Glaser 1985:70; Wooley 1987:176-179; and Schoelwer 1988). Also, many of the latter were reconstructed by parties not present at the scene who relied on dubious sources.

There may be some important information regarding the Alamo battle plans on file at the Mexican National Military Archives in Mexico City; however, apparently it is inaccessible (Anne Fox, Kevin Young, John Leal personal communications 1990). Even if the access problem could have been resolved, a trip to Mexico would have been beyond the scope of the 1989-1990 study. Since archaeological excavations at the Alamo have produced accurate and unique information on its general history, as well as on the form and history of the battle fortifications, further work of that kind is probably the most practical avenue for future research.

\section{Lunettes}

Lunettes are defensive fortifications that were built on the outside of main garrison walls. Depending upon the circumstances, they were either singular units or parts of multiple-component fortification systems. The term lunette derives from the French word lune (in English, moon) and its meaning within the context of fortification theory is interpreted to be half-moon shaped. Thus, it is an enclosure that is usually semicircular in plan configuration.

Classic construction elements of a lunette included an above-ground curtain or wall along the curved outer edge and a trench dug adjacent to and outside of the wall (See Palisades for a description of typical wall construction). The rear edge was usually a straight section of a pre-existing garrison wall. Fill from the trench was often banked against the outside of the curved wall to form a short, steep rampart. Some of the fill was also used to form a gentle slope, known as a glacis, that was inclined from the outer edge of the trench down to the ground or battlefield surface. Typically, there was an opening in the rear wall of a lunette leading to the interior of the garrison. There was also often an opening in the curved edge of a lunette called a sally port that allowed passage between the lunette and the field outside of the garrison and its fortifications. Lunettes were usually equipped with artillery pieces that were fired across the fronts of garrison walls at offensive troops, a process called raking-the-line.

The following definition illustrates the technical precision involved in the construction of 18th century lunettes, as well as other fortification features of the period:

Lunettes are works made on both sides of a ravelin; one of their faces is perpendicular to half or two thirds of the faces of the ravelin, and the other nearly so to those of the bastions... ...[they] are also works made beyond the second ditch, opposite to the places of arms; they differ from the ravelins only in their situation [Muller 1968:225-226].

It is also a good example of the formal archaic terminology and complexity of field manual definitions of the time. Additional definitions of lunette, and the meanings of such terms as ravelin, bastion, and place-of-arms may be found in the glossaries of Muller (1968), Viele (1861), Wheeler (1898), and Haythornthwaite (1979).

The lunette constructed outside of the south gate at the Alamo generally conforms to descriptions of lunettes found in the literature. The 1975 Alamo excavation revealed some of its structural details (cf. Fox, Bass, and Hester 1976:47). A substantial portion of the trench associated with the Alamo lunette was discovered in a relatively well preserved condition during the 1988 excavations. The layout of this trench suggests that the lunette was probably roughly rectangular, about $10 \times 20 \mathrm{~m}$.

The excavations of the trench also confirmed the fact that the southern end appears to have been tri-faceted in plan; thus, the lunette actually had six sides in its complete perimeter. This corresponds well to the shape of the lunette shown on two separate plan drawings of the Alamo that were probably made shortly after the March 6, 1836 battle by Mexican officers José Sanchez-Navarro and Ygnacio de Labastida. Considering the revelations of the archaeological work, it seems that no other known map of the Alamo fortifications depicts the lunette as accurately as the Sánchez-Navarro plan (cf. those in Schoelwer 1988 and Schoelwer and Glaser 1985).

The trench was virtually the only construction feature of the lunette encountered during the 1988 field school excavations. At that time, the interior deposits of several sections of the trench were completely removed and the sides and floor exposed. The locations and orientations of those 
sections suggest that they were portions of a relatively straight, north-south trending line of the trench that extended along the east side of the lunette. At a point about $16 \mathrm{~m}$ south of the location of the south wall of the Alamo, the trench turned sharply and headed straight along a bearing of about $223^{\circ}$. The section excavated along this heading is apparently a remnant of one of the three short sides or facets of the lunette trench that comprised its south end.

The trench was quite distinctive in appearance compared to the surrounding matrix. Its horizontal extent was well defined in transverse soil profiles by clearly visible interface planes that extended vertically between the interior and exterior matrices. For the most part, the interior matrix consisted of comparatively loose, finely-crossbedded, ash-stained layers of soil interspersed with caliche, stone rubble, and charcoal flecks. The natural strata on the exterior were much more compacted homogeneous soil and caliche layers and there was also an obvious color difference between the interior and exterior media.

In all of the areas exposed during the archaeological excavations, the trench was unlined, having been originally dug to a fairly uniform depth and width into a natural caliche formation. Well-preserved markings in the caliche walls and floor indicated that the original surfaces had been finished by careful picking, chiseling, smoothing and/or tamping. The careful design and construction of the trench would seem to indicate that it was done in accordance with a preconceived plan executed with military precision.

Cós' detachment from Mexico for the 1835 Battle of Bexar probably included between 1400 and 1800 able bodied men (cf. Eaton 1980:7; Castaneda 1928:202). According to the memoirs of General Vicente Filisola, a leader in the March 6, 1836 assault, the construction of the lunette, the palisade, and many of the other Alamo fortifications were the work of Cós' men:

El general Cós hizo terraplenar la cabeza de la iglesia hasta el cornizon, y formó de ella un caballero alto ó barbeta en que podian colocarse hasta tres piezas con alguna incomodidad: se subia á él por medio de una escala plana que comenzaba desde la misma puerta de la iglesia. Desde el ángulo que forman las paredes del solar que corren al Este y Sur, hizo abrir un foso $y$ alzar en línea diagonal un parapeto con una tronera en medio, prolongándose aquel hasta el ángulo del Sur que forma el frente de la iglesia al unirse con la pared que está en este mismo rumbo; en la puerta del repetido solar ó recinto se puso tambien un tambor en el que podian colocarse dos piezas, dejando la entrada por el ladoderecho [Filisola 1849:184].

Considering the context of the battle, this passage was translated by Anne Fox thusly:

General Cós filled in the head of the church up to the outer corner and formed with it a platform or earthen mound on which they could place up to three artillery pieces with some inconvenience. Access was by means of a ramp that began at the door of the church. From the corner made by the walls that run to the east and to the south, he had them open a ditch and raise diagonally a parapet with an embrasure in the middle. The parapet was projected to the south corner which forms the front of the church as it joins the wall that is in the same direction. In the door of the mentioned enclosure there was built also a tambour [stockade to defend an entrance] on which could be placed two artillery pieces, with the entrance on the right hand side.

\section{Palisades}

Palisades are linear vertical barriers, partitions, or walls, usually comprised of a row or more of adjoining posts or timbers. In the 18th and 19th century versions, the posts were typically cut in nine or ten foot lengths. A trench was dug along the line of fortification to a depth of about three feet and the posts were stood vertically and in close order upon the trench floor. Then soil was backfilled around the post bottoms and tamped until highly compacted. To increase stability, horizontal scabs or lintels were nailed to the back side of the wall toward the tops of the posts.

At the general level, palisades differ from lunettes in that lunettes are usually adjuncts or secondary features to a main garrison wall or walls or to a grouping of other fortification elements, but palisades may be sections of a main garrison wall or walls, as was the case at the Alamo. In some cases, a palisade may even comprise the entire main wall. Whereas the primary function of lunettes was to 
provide protection for surrounding sections of the main garrison walls, the main function of palisades was usually as a direct barrier to enemy advance.

Palisades frequently had ditches outside of and along the entire length of the wall of timbers. Fill from the ditches was often used to build a glacis (defined under Lunettes), and some of the fill was banked steeply against the outer side of the wall to add strength and stability and to make an approaching enemy's siege more difficult. Field manual definitions of palisade include the following:

...fence of pointed wooden stakes [Haythornthwaite 1979:182].

A high fence or barricade of pole timbers set vertically into the ground in a close row as a means of defense [Arana and Manucy 1977:62].

Pallisades are a kind of stakes made of strong split wood of about 9 feet long, fixed 3 feet deep in the ground in rows about 6 inches asunder [Muller 1968:227].

Palisades are triangular prisms of wood pointed at the upper end, and placed upright in the ground at 3 or 4 inches asunder; they are about 10 feet long, with faces 6 or 8 inches wide, and are sunk 3 or 4 feet in the ground. A trench of that depth is dug, the palisades are placed in it, and the earth is well rammed about them; they are connected at top (and sometimes at bottom also) by a ribbon of wood, called a lintel, 4 inches wide by $21 / 2$ thick, nailed to the inside of the palisades about one foot from the points; they ought to stand, at least, 7 feet out of the ground... [Viele 1861:122;cf. Wheeler 1898:174-175]

Palisades were used as defensive fortifications since prehistoric times over a broad portion of the globe including much of Europe and the Americas. For example, Lawrence Keeley and Daniel Cahen (1989:157-176) have presented archaeological data on extensive palisades used for defense of early Neolithic (ca. 6300-6000 B.P.) villages in Belgium. Referring to the site of the village of Darion located at the junction of the Geer and Faux Geer drainages, they describe an elaborate ancient palisade and ditch system there:
Darion's most extraordinary feature is its enclosure... the most prominent part of which is a V-sectioned ditch (1.5-2.5 $\mathrm{m}$ deep from the present surface...) surrounding the site. There were only three large gaps in this ditch, to the north, south, and west; the other apparent gaps...are the result of erosion or, in the case of several short gaps, appear to be original ones. This ditch is backed by an internal palisade that probably served as a buttress for a berm of earth excavated from the ditch. Multiple palisades occur at the north and south ends of the enclosure where large gaps or 'gates' appear in the ditch. At the south end, such palisades create what appears to be a 'baffle gate.' At the north end of the enclosure, a rectangular array of post molds may represent a battlement or tower foundation at the gap in the ditch. These works are clearly defensive in nature and enclose an area of about 1.6 ha [Keeley and Cahen 1989:160].

The close correspondence of the construction details and general cross sectional dimensions of the Darion palisade ditch to those of the Alamo palisade trench (Eaton 1980:51) seems quite remarkable. Interestingly, the tower-gate combination at Darion seems to be very similar to the one at the Alamo as described by Fray Mariano Francisco de los Dolores in 1762:

...the plaza is walled and above the gate [is] a tower with its loopholes [from Schuetz 1966:24].

The fact that palisades were used during prehistoric and early historic times in the New World is attested to in separate works by Alfred Kidder and James Deetz. Kidder (1924:44) alludes to the "occurrence of stockades" (to defend against the invading Athapaskans) that have been discovered at several prehistoric Pueblo Indian sites. Deetz notes the changes in the Arikara Indian village ground plans associated with pressures exerted on the Arikara by encroaching Europeans and Dakota Indians:

Prior to the pressures exerted on the Arikara...their communities were arranged in rather loose sets of 
houses, lacking in fortification... When the need for defense against enemies presented itself, the behavior of the community related to the arrangement of houses changed to a pattern placing emphasis on defense... This new pattern was that of tightly spaced houses, enclosed by a circular palisade and moat [Deetz 1967:119; emphasis added].

It is interesting that Cós may have constructed an analogous (though makeshift) moat at the Alamo by diverting an acequia that formerly ran through the interior of the compound to the exterior fortification ditches (Anne Fox and I. Waynne Cox personal communication 1990).

It appears that with regard to the Alamo palisade, as was the case with the lunette, construction details were never historically documented. The scanty information that is available about them is virtually all from secondary accounts (See Alamo Fortifications for reference citations). Thus, the 1977 CAR excavations at the front of the Alamo chapel revealed previously unknown details of the palisade (Eaton 1980:47,51).

The 1989 field school excavation near the low barracks failed to definitively locate the southwest end of the palisade; however, a well-preserved section of the accompanying outer trench that contained typical Spanish Colonial to early-19th-century battle-period artifacts was uncovered and documented. It proved to be quite similar in cross-sectional dimensions to the lunette trench sections found during the 1988 excavations. Its discovery raised the total number of archaeologically known trenches associated with the Alamo palisade to three. These include two narrower and shallower parallel trench segments located during the 1977 excavations near the southwest corner of the chapel, in which the palisade timbers would have been stood upright, and the section of the outer trench revealed during the 1989 excavation that would have been used as a soil borrow for berm construction. Construction details of the former and descriptions of artifacts associated with them are in Eaton (1980).

The archaeological excavations relating to the Alamo palisade seem to have eliminated some of the options concerning its construction that are presented in archival documents and later interpretations of those documents. For example, the 1977 dig revealed rather conclusively that the palisade was comprised of a double row of timbers, thus invalidating Ivey's (n.d.:26-27) single-row theory. A strong corollary implication is that the space between the timber rows would have been filled with packed soil borrowed from an adjacent outer trench (a remnant of which was found during the 1989 field school excavation). Without the soil packing, the rows of timbers would have provided little resistance to fire from Mexican artillery pieces. The trench sections discovered in 1977 are parallel and about six feet apart. According to military field manuals, that thickness of earth would probably have consistently withstood effective-range fire from six or perhaps even nine pounder cannons (cf. Viele 1861:95).

In spite of these revelations, there are some important questions about the Alamo palisade that have not been answered by the archaeological work performed there to date. Several descriptions of the Alamo fortifications refer to a sally port or gap at or near one or the other end of the palisade wall (cf. Potter 1933:91 and Eaton 1980:47). Those and other renditions of the palisade show varying numbers and configurations of defending artillery pieces behind the wall. Also, most of the plans and descriptions available portray the palisade as a straight line from the southeast corner of the low barracks to the southwest corner of the chapel, but it is possible that the palisade wall may have been curved, indented, or zigzagged.

During the 1989 field school investigations, an attempt was made to shed some light on the latter question. An experiment was conducted regarding the point of intersection (in plan perspective) of the east wall of the low barracks with the projection of one of the palisade walls as mapped by Eaton during the 1977 excavations. A survey instrument was set up at the location of the east end of the inner palisade trench near the Alamo chapel facade and the scope was aimed using the angle of $110^{\circ}$ formed by the chapel face and the trench center lines shown in his report (Eaton 1980:59). A stadia rod was then used to spot the approximate point along the north-south line of the east end of the low barracks where the palisade would have intersected the building.

Since the low barracks building had been removed, the 1989 experiment used an existing masonry flower bed border as the location of the south wall of the Alamo and the east wall of the barracks during the 1836 battle. The projected positions of the 1836-vintage features were fairly accurately established during the 1976 excavations and were used later that same year by the City of San Antonio Parks and Recreation Department as a base line for construction of some of the improvements to the Alamo Plaza park (Fox, Bass, and Hester 1976). Thus, in plain view, most of the 
modern flower bed border is virtually congruent with the old south courtyard and low barracks walls.

During the 1989 experiment, the point of intersection of the projection of the interior palisade wall and the hypothesized east low barracks wall was located about 20 feet to the north of what would have once been the southeast corner of the low barracks. According to all known accounts and plans, it should have been only about six feet to the north of the corner. There are several possible explanations that might account for some of this discrepancy. For example, Eaton's estimate of the angle between the chapel face and the ditch center lines was based on his interpretation of the trend of the two short trench segments discovered during the 1977 excavations. He admonished that there are inherent problems in making a close estimate of an angle when one of the segments is so short and somewhat erratic (Eaton personal communication 1990). The actual outer edges of the palisade trench segments found in 1977 would not have been as uniform as is implied in the idealized plan drawing in Eaton's report. Any variations along these trench edges would have been reflected in Eaton's estimated location and trend of the center lines. Also, the surveyor's transit used in the 1989 experiment may have been out of adjustment, misread, or set up erroneously.

Sometime in the mid 19th century Francois Giraud, then City Surveyor, made what is purported to be one of the more accurate maps of the Alamo (Anne Fox and I. Waynne Cox personal communication 1990). According to Giraud's map, the $110^{\circ}$ angle that Eaton measured in 1977 should have been closer to $127^{\circ}$. Even allowing for some error in Eaton's interpretations, this $17^{\circ}$ discrepancy between the two measurements seems difficult to ignore. It could indicate that the shape and/or the location of the palisade differed substantially from that typically shown in archival sources (i.e., a straight line of timbers spanning the space between the southeast corner of the low barracks and the south end of the chapel facade).

Future archaeological excavations between the Alamo chapel and low barracks could probably resolve this and other enigmas concerning the palisade. Even if it is later somehow verified through non-archaeological means that the palisade timber trenches did intersect the southeast corner of the low barracks in the manner typically portrayed, the 1989 excavations have shown fairly conclusively that the physical evidence for the intersection has been destroyed. This may have occurred in the late 19th century during landscaping renovations of Alamo Plaza.

\section{Summary and Conclusions}

The goal of the 1989-1990 research was to gather as much information as possible from archival sources regarding the Alamo palisade and lunette within the course of an investigation spanning approximately eight weeks. Unfortunately, no new primary accounts of the battle of the Alamo or its fortifications were discovered. Even the most credible and coherent renditions found in the secondary sources do not address the subject of fortification to any appreciable extent. Also, many of the accounts were written from memory long after the battle, in emotionally charged prose, and are mutually contradictory.

Given that the Mexican National Military Archives are off limits, the research probably was fairly exhaustive. Future archival studies could probably at best be only slightly more productive due to the scarcity of reliable sources. Thus, it is important that further archaeological work be performed at the Alamo in order to learn more about its early-19th-century military fortifications, such as the lunette and the palisade.

\section{ARCHAEOLOGY ON THE ALAMO GROUNDS}

Archaeological investigations have taken place on the Alamo grounds since 1966. These have generally been done in response to plans for projects which would penetrate the surface of the ground, such as the installation of buried electric lines or excavation for wall footings. In each case, important information has been obtained on architecture and building sequences at the site, and numerous 18th- and 19th-centuries artifacts have been recovered.

Excavations from June 1 to mid-July 1966

Test excavations were conducted from June 1 to mid-July 1966 in seven areas in the Cavalry courtyard and convent courtyard after artifacts had been found during excavation for electric lines. The project was directed by John Greer (1967) for the State Building Commission and the Witte Museum.

Results: (1) Recorded comparative depths of Hugo and Schmeltzer Company, U.S. Army, battle, Spanish Army and Spanish mission occupations.

(2) Recorded flagstone floor and wall relating to mission work rooms at the west 
end of the Cavalry courtyard.

(3) Confirmed that the wall between the courtyards rests on original footings.

(4) Uncovered the remains of a brick pavement in the southwest corner of the convent courtyard.

(5) Located an adobe foundation beneath the present well courtyard that predates the convent.

Excavations from August to September 1970

Test excavations were done prior to an addition to the DRT Library. They were directed by William W. Sorrow (1972) for Texas Archeological Salvage Project, The University of Texas at Austin.

Results: (1) Recorded the condition and location of the acequia at the library's currently restored section.

(2) Documented the foundation of the brick store building which earlier stood in the area

(3) Recorded evidence that stone lining was a later addition to the acequia in this area.

Excavations from March to early April 1973

Test excavations were done at the east end of the Cavalry courtyard in advance of planned wall construction in March and April 1973. Mardith Schuetz (1973) directed the project for the Texas Archeological Salvage Project, The University of Texas at Austin, and the DRT.

Results: (1) Located the early foundations of an east courtyard wall.

(2) Recorded room wall foundations against the east wall.

(3) Located what was thought to be the original north wall line of the courtyard.

Excavations in November 1973

Test excavations to the east of the Museum building were directed by Dr. Thomas R. Hester, UTSA, for the DRT.

Results: (1) Confirmed that the currently restored acequia follows the course of the original.
(2) Sampled debris in basements of late-19th-century and early-20th-century commercial buildings which once stood to the east of the acequia.

(3) Confirmed there had been no mission buildings east of the acequia.

Monitoring in January 1977

Backhoe trenching outside the west wall of the Long Barracks in connection with the City's repaving of the area was monitored by Anne Fox (notes on file at CAR), UTSA, for the City of San Antonio in January 1977.

Results: (1) Confirmed that the building is set on the original footings.

(2) Recorded construction details of the footing, original wall base, and later construction of the wall.

Excavations in March 1979

Test excavations were done in the Cavalry courtyard in conjunction with removal and reconstruction of the north wall in March 1979. Anne Fox (n.d.), UTSA, directed the project for the DRT.

Results: (1) Recorded archaeological remains of a sequence of walls on north wall line.

(2) Discovered and documented the Mexican defensive trenches inside the courtyard and around the northeast corner.

(3) Discovered and documented first route of the acequia, a later U.S. Army drainage ditch, and an early-18th-century Spanish adobe structure.

(4) Recovered and reconstructed the skull of a participant in the 1836 battle, along with numerous artifacts of the battle.

Investigations in January 1980

Investigation of the foundations of a small stone house behind Alamo Hall (occupied in the 1860s by San Antonio Mayor W. C. A. Thielepape) was directed by James Ivey, UTSA, for the DRT in January 1980. 
Results: (1) Located and documented the house and kitchen foundations.

(2) Reconstructed the history of the park area around the Alamo site.

(3) Compiled Thielepape's biography.

From these brief summaries it can be seen that archaeology provides much valuable information about the history of the site and of the various structures which have existed at different times on the Alamo grounds. We have also demonstrated beyond doubt that a tremendous amount of information is still preserved beneath the surface throughout the park.

\section{ARCHAEOLOGY IN ALAMO PLAZA}

The first professional archaeological excavation in the area of Alamo Plaza was done by the Center for Archaeological Research in 1975 (Fox, Bass, and Hester 1976), in advance of an extensive park renovation. The purpose of the project was to determine whether any structural remains of the south wall barracks building still existed beneath the surface of the park. The careful excavation of two trenches across the park revealed the following stratification (depths are approximate): $70 \mathrm{~cm}$ of dark gray clay loam fill, $30 \mathrm{~cm}$ of dark brown clay loam fill, $15 \mathrm{~cm}$ of medium gray midden soil from the old plaza surface, $50 \mathrm{~cm}$ of light to dark tan granular soil with limestone rubble, 5 to $10 \mathrm{~cm}$ of yellowish calcareous clay overlying caliche bedrock.

Remains of the footing for the south mission wall and for the later barracks built against it were found embedded in the tan granular soil layer near the bottom of the trench. The bottoms of the footings were 1.75 meters or 5.70 feet below the present surface. Although severely disturbed, the footings were still clearly visible as intrusions into the subsoil. An interesting and important feature found during the excavations was one end of the fortification trench dug in 1835 or 1836 to protect the gate in the south wall. This has been depicted variously on different maps of the Alamo as it was in 1836 (Chabot 1941:59, 75; Santos 1968:164). The trench was found in the same tan granular soil layer as the footings. It is $2.0 \mathrm{~m}$ across, and the bottom is approximately $2 \mathrm{~m}$ below the present park surface.

The trench was a most important find for a number of reasons. Location of the north end of the trench supports our proposed location of the mission's south wall. The location of the trench also implies the location of the gate. The contents of the fill in the trench confirm the approximate date of the construction of the wall (when midden material would have started to accumulate in this area), and the date of the refilling of the trench (Fox, Bass, and Hester 1976:52).

In 1977 , in connection with a repaving project, the CAR conducted brief test excavations against the southwest corner of the facade of the church. These excavations, directed by Jack Eaton (1980), allowed careful examination and recording of the footings beneath the church. An unexpected feature revealed in these excavations was a short section of the palisaded fortification wall that stood between the church and the south wall barracks during the 1836 battle. The remains consisted of two palisade trenches six feet apart. The fill in the trenches contained lead and bronze balls, howitzer shell fragments, metal and bone buttons, and a variety of ceramic, glass, and metal fragments. Unfortunately, time limitations did not allow further excavation to locate the ditch to the south of the palisade wall. This ditch shows on every drawing and map made of the battle site and probably contains important information on activities in 1836. Excavation of this ditch would also confirm whether or not it was once filled with water, as recorded by later artists.

In 1979 to 1980 and 1983, the Center for Archaeological Research conducted excavations at the southwest corner of Alamo Plaza, directly across from the church. The information gained was used during construction of the Paseo del Alamo park, where the west wall and the Indian quarters built against it in that area were later reconstructed to about three feet in height. Structural and artifactual information recovered during these excavations have been useful in interpretation of this part of the plaza for the public.

\section{AND 1989 FIELD SCHOOLS INVESTIGATIONS}

\section{RESEARCH DESIGN}

The research design for the 1988 field school was originally intended to focus on the lunette area, to discover the exact size and shape of this feature as well as to examine any other structures that may have existed before or after the battle in this area. The contents of the fill in the trench were expected to represent all the events that had taken place in the general area from the time when the mission was moved to this site in 1724 to the refilling of it the after the battle in 1836 . 
It was also speculated that the trench fill would help to date the artifacts recovered from the excavation of the La Villita Earthworks excavated by the CAR in 1986 (Labadie 1986). Therefore, it was decided that a large percentage of the trench fill should be recovered for study.

The results of the 1988 field school were so encouraging that the 1989 field school was planned to enlarge upon and complement the work done in 1988. There were several questions that so far had not been answered by archival research. One had to do with the actual design and construction of the palisade wall and ditch that reached from the church to the low barracks. How did this wall attach to or approach the low barracks? Was there an opening between them, as shown on some maps? Was the ditch connected in some way to the acequia system and contain water? When and how were the one-story rooms shown perpendicular to the low barracks (Figs. 2 and 3 ) built and by whom? How does the fill in this ditch compare to that of the lunette trench and what can we learn from any differences or similarities?

\section{METHODOLOGY}

In order to prepare the area for excavation of the lunette trench, a backhoe was used to remove ca. 80 $\mathrm{cm}$ of modern fill over a large portion of the site to the south of the planter (Fig. 6), which removed the top layer of dark gray clay loam park fill and about $10 \mathrm{~cm}$ of the lower brown clay fill found in 1975 . An island about $5 \times 8.5 \mathrm{~m}$ was left undisturbed in order to protect a large Live oak. Further shovel scraping and leveling removed this deposit to the level of the old plaza surface. A grid of 1 meter squares aligned on magnetic north was then laid out over the entire area, and specific units were chosen to begin excavation. The exact units to be excavated were dictated by the location of the 1975 trench which was clearly visible in the north wall of the cleared-out excavation area.

Twenty-one students participated in the 1988 field school, making a total of approximately 350-man days spent in excavation, allowing for three days when rain made the site too wet to work. In addition, one day was spent after the end of the field school excavating an area to the south of the field school site with the aid of the backhoe, in order to follow out the line of the lunette as far as possible within the park. This operation was stopped, on recommendation of Parks and Recreation Department personnel, when it approached the point where further excavation would endanger a large Spanish oak on the west edge of the park (Fig. 6).

Vertical control was established with a transit for which the datum was set in the planter to the north of the excavations (Fig. 6). Comparative depths with those established in 1975 were recorded by reference to the same spot on the facade of the Alamo chapel as used for that excavation (Fox, Bass, and Hester 1976:37, Fig. 13). This was necessary because the 1975 park surface had been altered by new park construction in 1975-1976.

All soil removed during the controlled excavations was passed through $1 / 4$-inch screens. A metal locator was used to check the backdirt from the screens for small metal objects such as musket balls that might have been missed in screening. Artifacts recovered were placed in bags labeled with provenience and taken daily to the archaeological laboratory for processing. All units placed over the lunette trench were excavated to the bottom of the trench, at approximately $100 \mathrm{~cm}$ below the surface of the excavation area. Units dug elsewhere in the area were dug to sterile soil, or until the desired structural information was recovered. A one-meter balk was left in the lunette trench in order to observe and record profiles of the trench fill. Additional profiles were recorded as excavations proceeded. In addition, students maintained detailed level-by-level notes on field procedures and their personal observations.

All field school activities were recorded with a Curtis Mathes Color Video Camera, Model KC768 and a Curtis Mathes Color Cassette VCR, Model KV773. Detailed descriptions of this equipment and its use in recording the operations are on file in a report composed by the cameraman as part of his participation in the field school. In addition, black and white and color photographs were taken of the field school in progress. The VCR tapes and photographs are on file at the CAR along with all the other documentation of the work.

\section{THE EXCAVATIONS}

Three distinct areas of concentration were the focus of concern during the 1988 field school. As mentioned previously, the location, extent, and construction of the lunette trench was of primary concern. Information was also sought on the location and configuration of the gate structure in the south wall, shown on most maps as having a triangular projection on either side of the gate. In addition, it was hoped that information on the construction of the actual lunette fortification might 


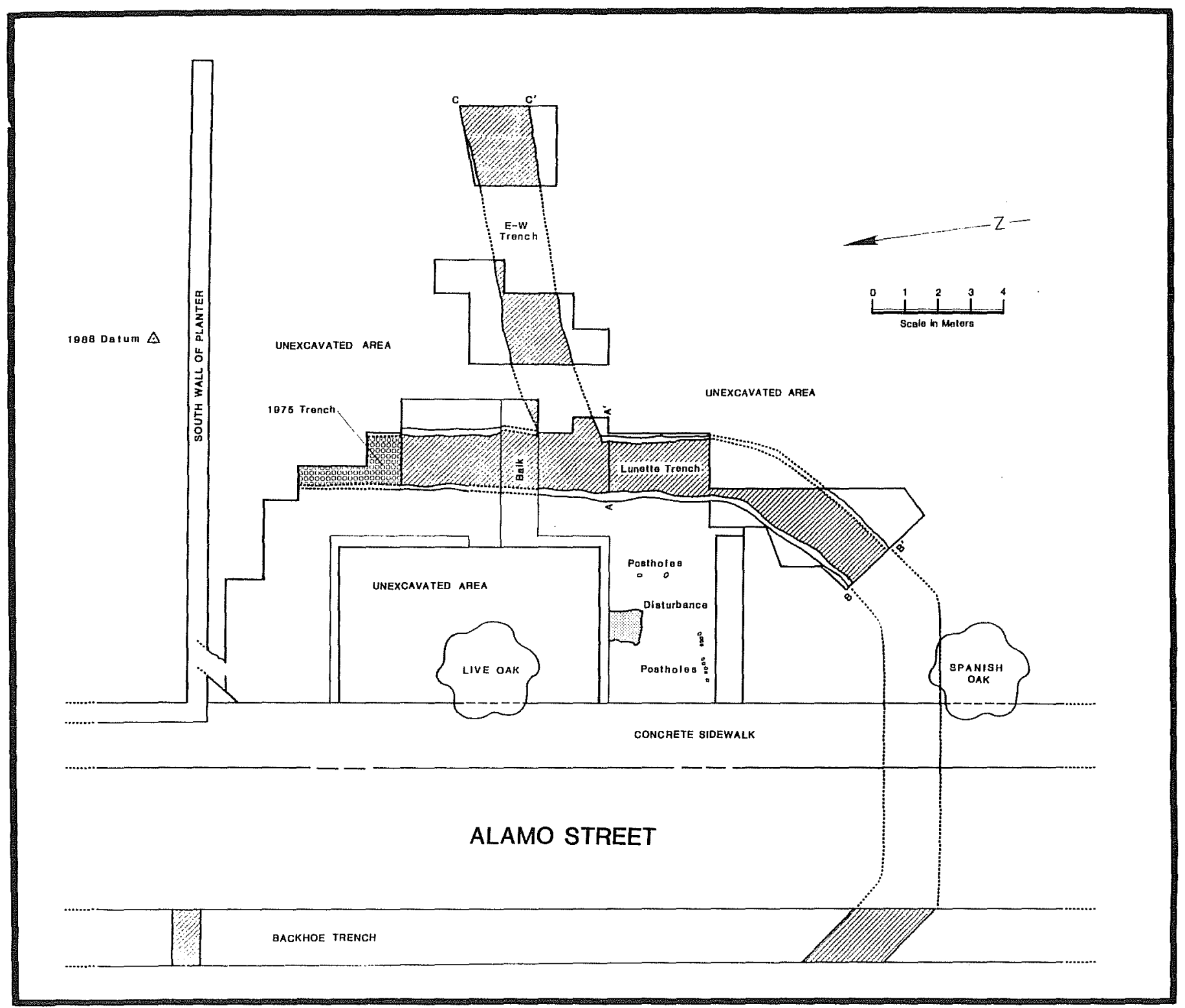

Figure 6. Plan of the 1988 Field School Excavations. Hatchured areas indicate trenches revealed within excavations. 
be preserved within the curve of the trench. The area was initially divided informally into three projects, each with crew chiefs and groups of students.

There are two basic ways to conduct the excavation of a feature such as the lunette trench: stratigraphically according to natural or man-made deposits, or by arbitrary levels, ignoring stratigraphy. The lunette trench was excavated in arbitrary $20-\mathrm{cm}$ levels, since the 1975 excavations had demonstrated that the stratigraphic recording of the trench contents was not productive. It soon became apparent that the trench contents contained numerous strata (Fig. 7,a), some that were comparatively sterile and some culturally rich, indicating that loads of fill had come from various locations outside the gate. The midden deposits were characterized by concentrations of ash and charcoal, as well as both mission and early 19th-century artifacts along with numerous musket balls.

In the lowest stratum of fill, just south of profile A-A', the excavators came upon a thin, cuprous metal plate from a military shako. This object was lying face down on the bottom of the trench. The Morelos Permanente Battalion from which it came (see Artifact Analysis section) was the group that carried out the fortification of the Alamo for General Cós in late 1835. They did not return to San Antonio in time to participate in the battle of March 1836 (Sam Nesmith, personal communication). Therefore, we have here confirmation that General Cós fortified the main gate in 1835 .

Deposits in the north-south portion of the trench were richer in household-related items than those filling the section of the trench that turned toward the west at the south end. This is probably because of the closer proximity of the former section to the midden deposits, which formed a good part of the fill.

The lunette trench was found to be relatively flat on the bottom and to slope outward slightly from the bottom to the top. The shape was symmetrical throughout the north-south leg of the trench, but gradually sloped more on the north side as the trench turned toward the west at the south end (Fig. 7,b). Since we have no idea of the exact ground level in 1835-1836, we cannot determine its original depth, but the bottom was approximately $100 \mathrm{~cm}$ (ca. 3 feet, 3 inches) below the level of the deposits identified in 1975 as being the surface of the plaza in the 1850s. This is considerably short of the eight-foot-measurement reported in later accounts, but the same depth as that recorded for the 1975 excavations at the north end of the trench.
Several days after the end of the field school, excavations with the aid of a backhoe followed out the line of the lunette trench toward the south until it turned southwest. Careful cleaning and mapping of the trench walls revealed that the trench turned at an angle of approximately 45 degrees just south of where the field school excavations had stopped. Projection of the probable line of the lunette trench, and therefore the fortification within it, was then possible as indicated in Figure 6. A profile drawn of the southwest end of these excavations shows the cross section of the lunette trench at this point (Fig. 7,b).

In July 1988, as part of the utilities relocation for the Tri Party downtown renovation project, Waynne Cox of the CAR staff monitored the excavation of a north-south trench within the roadbed of Alamo Street (Cox n.d.). Although the trench encountered severe disturbance to the north and south of the field school location, the area between the mission's south wall and the lunette was undisturbed. It was possible, therefore, to map in the continuation of the lunette trench where it crossed the utility trench, as well as the foundation of the south wall (Fig. 6). These fortuitous remnants add to and confirm the findings of the 1975 and 1988 field work.

At a point nine meters south of the planter wall, a gap was noted in the east wall of the lunette trench. Additional excavation units in the area exposed a side trench going east from the lunette. The configuration of this trench was different from that of the lunette in that the walls sloped outward and the bottom curved downward, resulting in a more semicircular profile (Fig. 8,a).

Artifacts recovered from the fill of this east-west trench were much the same assortment as those from the lunette trench, but were not as numerous and appeared to peter out gradually toward the east end. There was also much less ash and charcoal in this fill. This is probably the result of taking the backfill for this trench from an area farther and farther away from the gate midden, and in an area where access from the inside of the mission was barred by the south wall and barracks. The east-west trench was followed out by putting in additional units up to the east edge of the backhoe excavation.

At the northwest corner of the area cleared for the field school, a triangular-shaped mass of caliche was uncovered in the corner next to the south wall of the planter. This anomaly appeared to be part of the footing for the triangular projection on the east edge of the gateway, as indicated on various Alamo maps (Figs. 1, 4, 5). Proceeding on the premise that this indicated the edge of the gateway construction, 


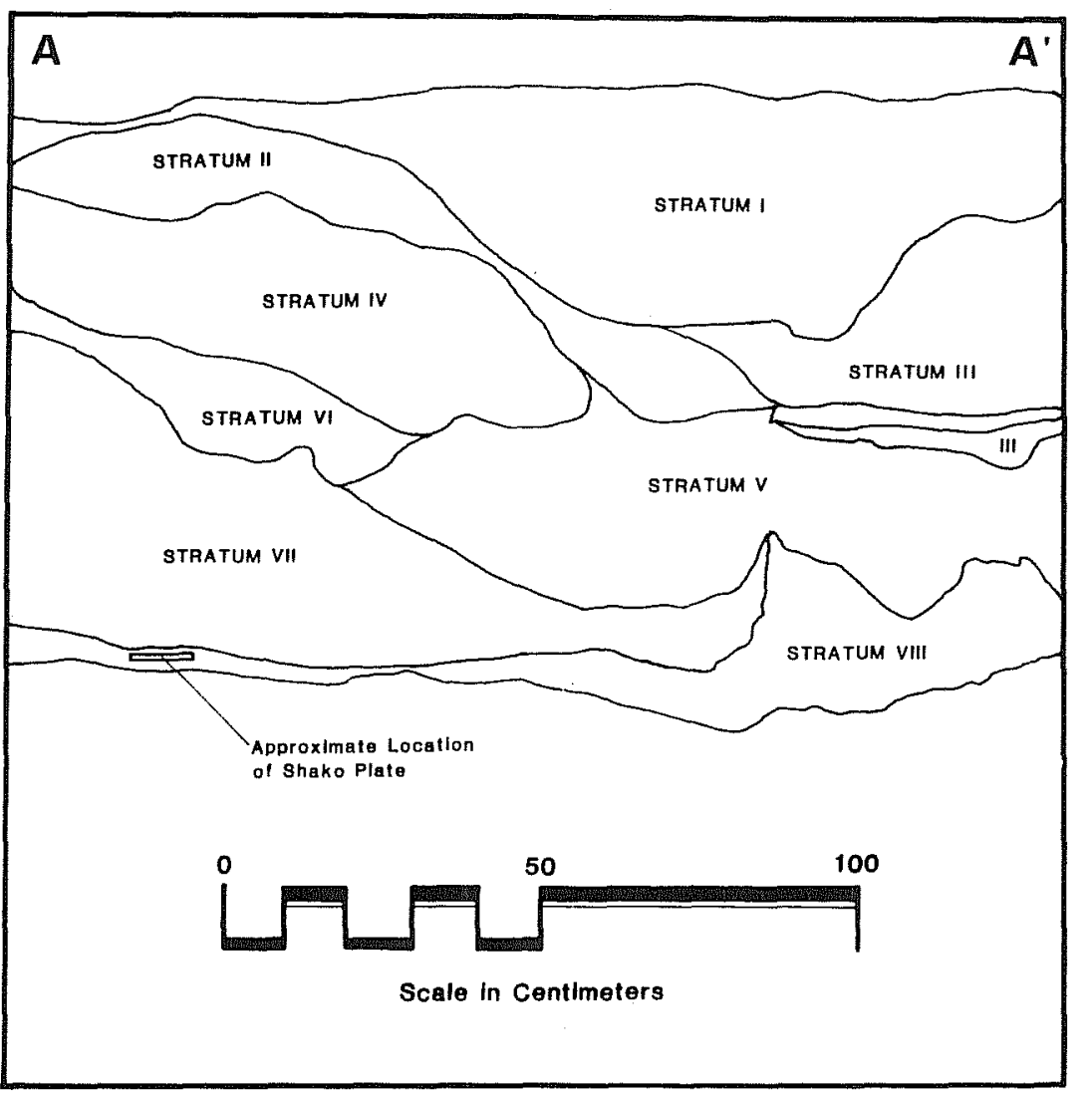

a

Figure 7a. Lunette Trench Profile $A-A^{\prime}$.

Stratum I. Light grayish brown soil mixed with caliche and charcoal flecks - 10YR 6/2 Stratum II. Dark grayish brown porous soil - 10YR 4/2

Stratum III. Grayish brown porous soil mixed with caliche and charcoal flecks - 10YR 5/2

Stratum IV. Very dark grayish brown porous soil - 10YR $3 / 2$

Stratum V. Very dark grayish brown fine silty soil 10YR $3 / 2$

Stratum VI. Dark brown soil mixed with some caliche - 7.5YR 4/2

Stratum VII. Dark grayish brown fine silty soil - 10YR $4 / 2$

Stratum VIII. Pale brown sand mixed with caliche - 10YR 7/3

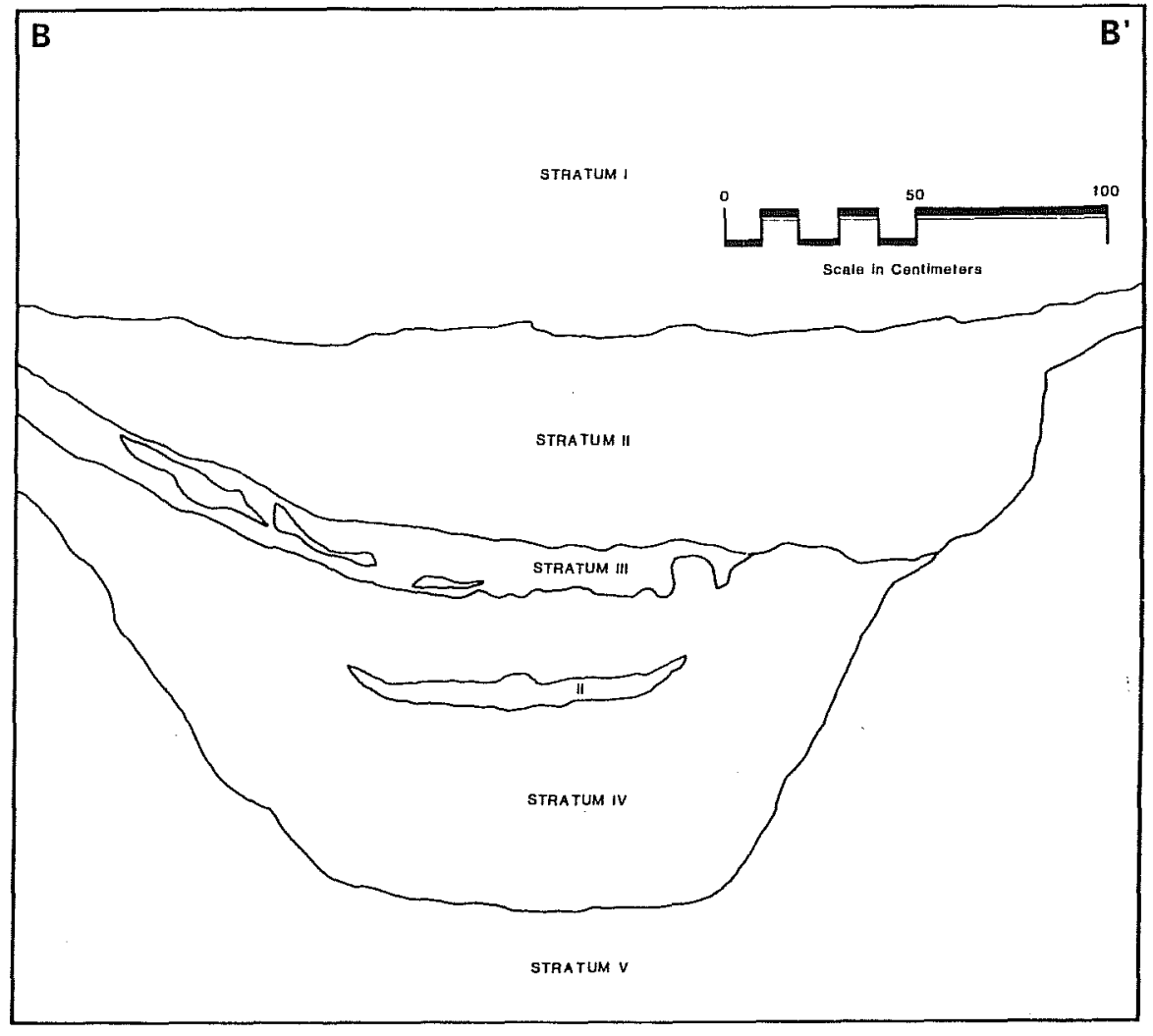

b

Figure $7 \mathrm{~b}$. Lunette Trench Profile B - $B^{\prime}$.

Stratum I. Very dark brown mixed with light yellowish brown dense clay mixed with small rock, roots - 10YR $2 / 2$ and $10 \mathrm{YR} 6 / 4$

Stratum II. Pale brown - 10YR 6/3

Stratum III. Dark brown soft clay mixed with small rocks - 10YR 3/3

Stratum IV. Grayish brown dense soil mixed with small pebbles \& specks of charcoal - 10YR 5/2

Stratum V. Very dark grayish brown fine soil mixed with a small rocks toward the bottom 10YR $3 / 2$

Stratum VI. Dark brown soil mixed with many rocks and pebbles - 10YR 3/3

Stratum VII. Pale brown caliche mixed with sand - 10YR $6 / 3$

Stratum VIII. White caliche - 10YR $8 / 1$ and $8 / 2$ 


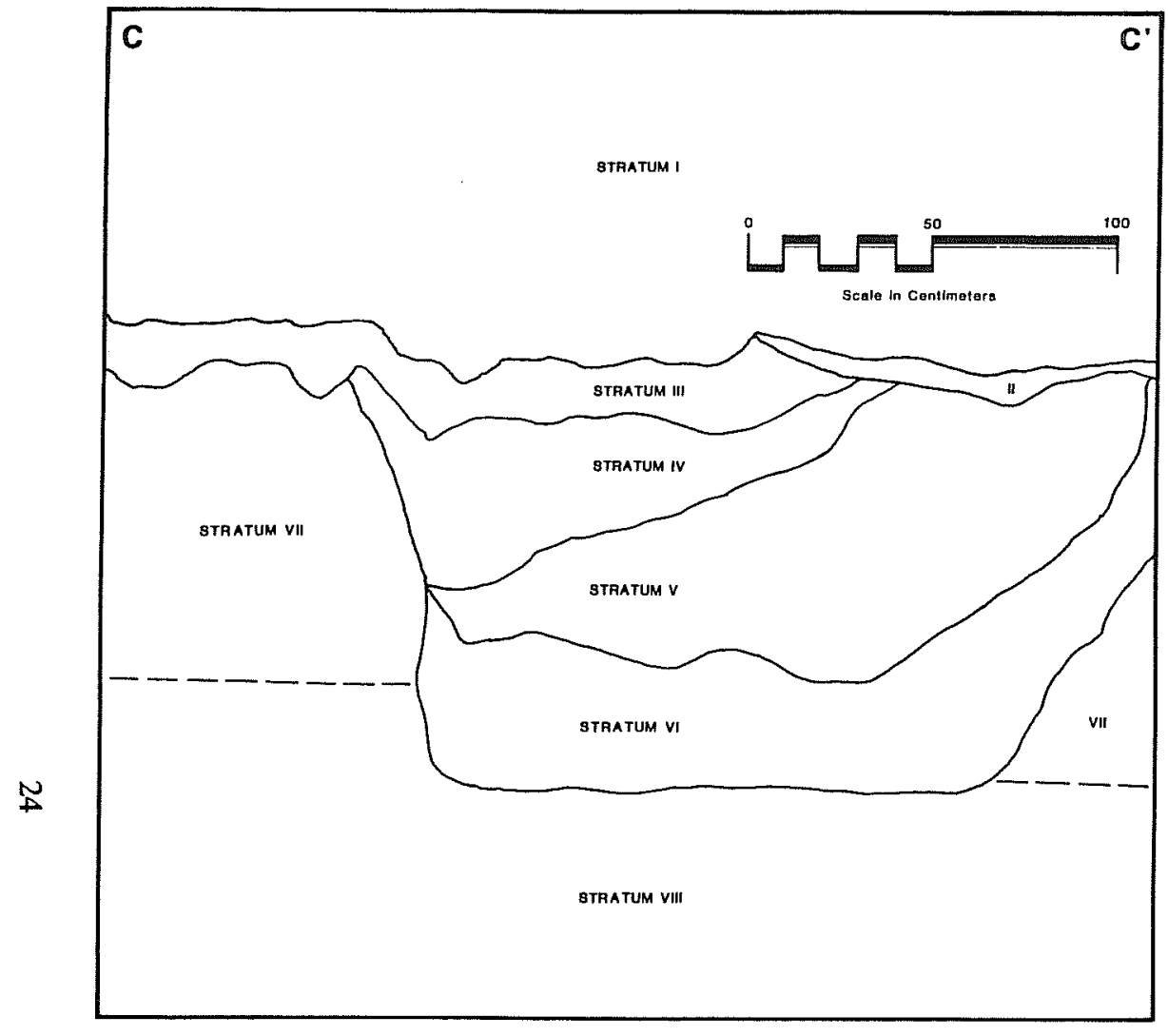

a

Figure 8a. East-West Trench Profile $C$ - C'.

Stratum I. Dark grayish brown dense clay with small rocks - 10YR 3/2

Stratum II. Dark grayish brown loam with caliche - 10YR 4/2

Stratum III. Pale brown caliche with loam - 10YR 6/3

Stratum IV. Very pale brown caliche with sand - 10YR $7 / 3$

Stratum V. White caliche - 10YR $8 / 2$

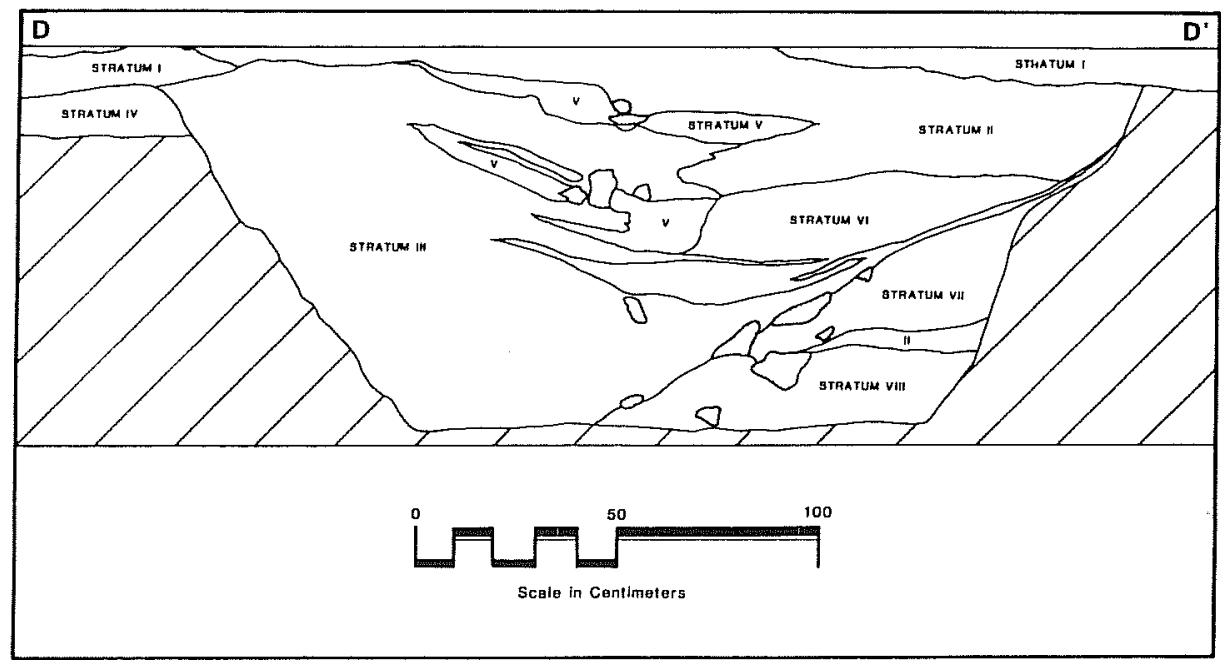

b
Figure 8b. East-West Trench Profile $D-D$ '.

Stratum I. Black clay - 10YR 2/1

Stratum II. Dark brown gravely soil - 10YR 3/3

Stratum III. Caliche fill - 10YR 6/3

Stratum IV. Brown gravely soil - 10YR $5 / 3$

Stratum V. Dark brown/black soil - 10YR 3/2

Stratum VI. Light brown gravely soil - 10YR 7/3

Stratum VII. Light brownish gray fill - 10YR 6/2

Stratum VIII. Tannish soil - 10YR 7/2 
excavation was extended toward the north beneath the planter to determine the location of the face of the south wall footing. Unfortunately, as found also during the 1975 excavations, the wall footing had been severely disturbed by previous demolition in the area. However, a gray adobelike soil with large caliche inclusions was found just behind the shallow concrete footing of the planter, which is probably the remains of the south wall footing. To the east of the exploratory trench, a disturbance filled with sandy clay was found to be a late 19th or early 20 th century utility trench with a pipe at the bottom.

An area $3 \times 5 \mathrm{~m}$ in extent at the southwest of the field school excavations was investigated with particular care in hope of encountering remnants or indications of the construction of the lunette fortification. In the first three levels of excavation $(30 \mathrm{~cm})$ the same mixture of $18 \mathrm{th}$ - and early 19th-centuries artifacts was encountered as found in the lunette trench fill, with the amount decreasing with depth. A peculiar feature in the north half of the excavation area at first was thought to be structural. However, further investigation indicated that it was a later disturbance, probably created post -1950 by a backhoe which would account for the regularity of its outline. A bronze mortar shell fragment found in the fill of the feature was evidently an accidental inclusion from the surrounding soil when the feature was refilled.

Two $10-\mathrm{cm}$ post holes were found at the $30-\mathrm{cm}$ level in these excavations (Fig. 6). Two Goliad ware sherds were found in what appeared to be undisturbed context close to the base of one of these. Both posts were surrounded with a mixture of caliche and small stones. These may be the remains of either a palisade structure that was part of the fortification or something to do with the anchoring of the cannon within it.

In the southwest corner of the area, a row of seven postholes was found. There was no apparent connection between these and the previous post holes, although they were approximately the same size. Excavation of a larger area within the lunette would be necessary to understand the origin of these features.

\section{METHODOLOGY}

The 1989 field school was conducted from June 5 to July 7 . There were 18 students participating and approximately 350 -man days were spent in excavation.

The intent of this season's work was to determine if the east-west trench continued to the east and became the trench dug in connection with the palisade fortification between the church and the low barracks, and to find out how and where the palisade wall met the low barracks corner. In addition, it was hoped that information might be obtained on the north-south addition of the barracks built sometime after 1802 , still present in 1836 (Fig. 2), but gone completely by 1849 (Figs. 4 and 5). In order to attempt to answer these questions, a long, narrow excavation area (Fig. 9) was opened in the western edge of the street between the Alamo church and the park (Fig. 10). The width of the area was set by the necessity to have two lanes of traffic continue in the street throughout the field school.

Since the street had been paved with flagstone during the 1975-1976 renovation, it was necessary for city workmen to remove the pavement. An area ca. $3.2 \mathrm{~m} \mathrm{x} 17.6 \mathrm{~m}$ was cleared off to the soil beneath the paving. A grid of $1 \mathrm{~m}$ squares was then laid out, aligned with the centerline of the opened area. A datum for vertical control was established within the planter, taking a back sight on the 1988 datum (Fig. 9). As with the previous field school, elevations were referenced to the same point on the church facade as used in 1975.

The field director and the students kept daily logs of the work, and filled out level report forms. Profile drawings, maps, and sketches of features were continually produced. Black-and-white and color slide film were used to record the excavations.

Artifacts were recorded in place wherever possible, and assigned field numbers. Soil removed was screened through $1 / 4$-inch mesh screens and artifacts recovered were placed in properly labeled bags and returned to the laboratory daily. Units were excavated to and often into sterile soil in an effort to understand the formation of site features.

\section{THE EXCAVATIONS}

The first stratum encountered beneath the base material of the street paving was a dense, dark gray brown clay which contained no artifacts. After some attempt to trowel this material, it was decided to remove it without screening to the top of the next stratum - a medium brown, friable soil. At this point, controlled excavation began in $10-\mathrm{cm}$ levels. Nineteenth century artifacts were found at the contact between the clay and the second stratum and into that stratum.

When the clay stratum was stripped from the three units at the south end of the excavations, it was apparent that the deposits there were different from 


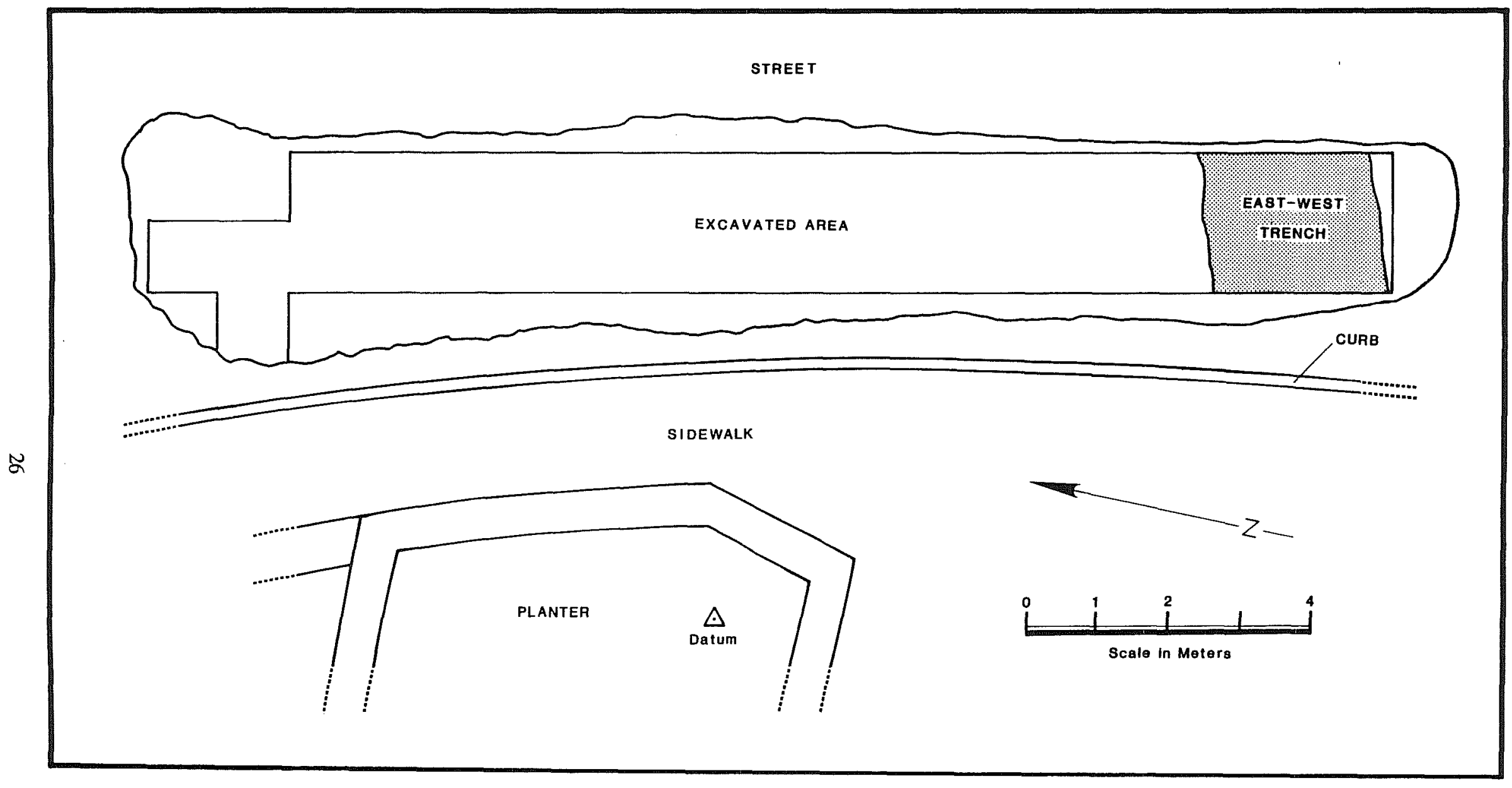

Figure 9. Plan of 1989 Field School Excavations. For location, see Fig. 10. 


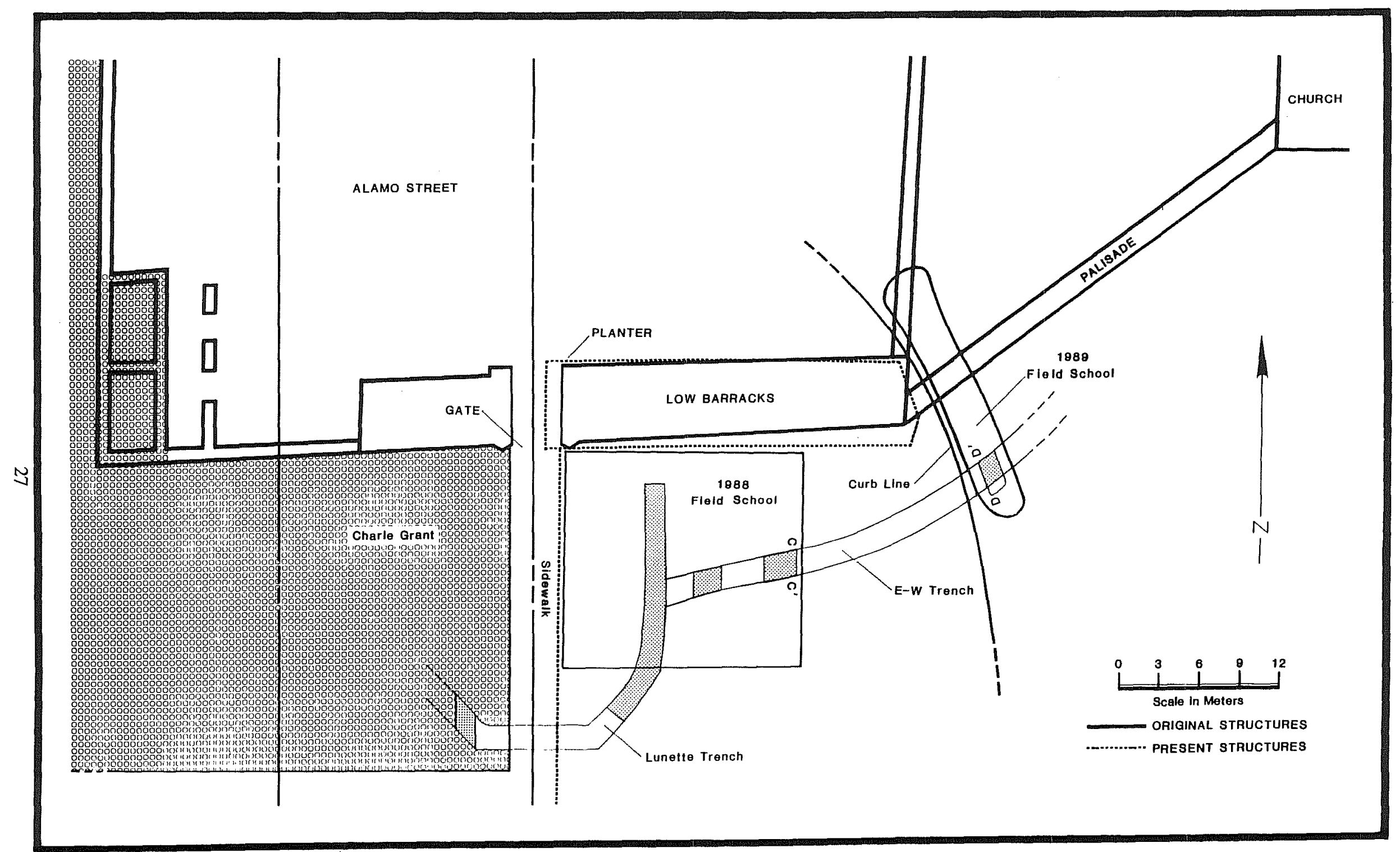

Figure 10. Composite Plan of South Wall Area. 
those in the rest of the excavation area. This had been anticipated, since these units were in line with the east-west trench located and mapped in 1988. A few sherds of Spanish colonial ceramics were recovered in the first level of excavation in this area. Additional clearing and excavation of the top $10-\mathrm{cm}$ level narrowed down the estimation of the trench width to a little over $2 \mathrm{~m}$. The trench was then excavated in $10-\mathrm{cm}$ levels to the bottom, keeping careful control by leaving and recording a north-south balk in the center. The same mixture of sterile layers and layers containing charcoal and artifacts was encountered as in the trench excavations in 1988 (Fig. 8,b). The shape of the trench at this point was quite different than it was found to be farther west in 1988. The configuration of the fill strata was also quite different. During excavation it became apparent that much of the trench fill consisted of caliche. Most of this seemed to be concentrated toward the south side of the trench, as if individual shovels full or loads of this material had been tipped into the trench from that side. Since the trench had initially been dug into the caliche subsoil, this material probably is what was excavated when the fortification was constructed. Its proximity to the south side of the trench suggests that the caliche excavated in order to create the trench was piled along the south edge in order to create a berm or glacis along that side. This would have been consistent with military tactics of the period (see Uecker's discussion on military construction).

The central portion of the excavation area was found to consist of a travertine/caliche formation which contained numerous hollows and fissures filled with sterile dark brown soil. Just above and around this formation, the medium brown, friable soil of Stratum II (mentioned previously) contained a mixture of 18th- and 19th-centuries artifacts. After considerable discussion, it was the tentative conclusion of the field crew that the travertine represents a spring deposit of late Holocene origin (Gunn et. al. 1989:7). From the time of its founding in the early 18th century, many springs have been noted in the vicinity of the town, several as nearby as the bank of the San Antonio River two city blocks from this site (Cooley 1900:55). These springs have shown a surprising ability to reassert themselves in times of bountiful rainfall. The occasional rejuvenation of this spring in the plaza may well be the reason for the numerous complaints of the citizens of 19th century San Antonio that Alamo Plaza was often a quagmire and not to be crossed at night without a lantern (Newcomb 1926:93; James 1938:94)). It is also interesting that several stone
Indian artifacts (a scraper, a hammerstone, a core, and several tested flint nodules) were recovered in the vicinity of the travertine deposit (Gunn et. al. 1989:10), which might indicate attraction of people to an early water source.

Since the area where the excavations were done was once beneath an earlier city park (Robichaux 1989:2), it seems possible that at least some of the uneven interruptions in the travertine deposit may have been the result of the growth of various shrubs and trees in the park. Unfortunately, none of these features were sufficiently linear or regular to be considered palisade trenches or post holes. A carefully drawn profile of the entire east wall of the center section of the excavations also failed to indicate any trace of trenches or post holes.

An area ca. $3 \mathrm{~m}$-square at the north end of the excavations yielded a concentration of late 19th century artifacts in dark brown clay soil at the Stratum II level. Traces of sandy mortar and a few medium sized limestone fragments suggest that some sort of construction was done in the general area, but no structural remains such as footings or post holes were found. As this area was heavily used by U.S. Army Quartermaster wagons in the last half of the 19th century, one would expect to find artifacts of this period present. A few mission-related materials were found in the lower levels.

\section{ARTIFACT ANALYSIS}

Description of artifacts in archaeological reports varies widely. Some describe every artifact down to individual nuts and bolts. Some limit the reporting to tables of provenience with little if any mention of individual artifacts. In this report, artifacts are described on two levels of intensity:

General - discussion of categories with specific examples of interest described and illustrated, and

Particular - categories handled in more detail which include those of special interest or importance either to the interpretation of the site or because they are unusual and would be of interest to other archaeologists working in similar sites.

Thus, ceramics are described and illustrated because this site provides important clues for dating the arrival of specific decorative types and individual designs in the San Antonio area. Information gained from this analysis can be used to date ceramics from other early-19th-century sites in the San Antonio area, and perhaps elsewhere in Texas. The horse equipment is described in some detail because many of the items are not often found 
in Texas sites. The same is true of the arms and military equipment categories. The detailed handling of the arc light carbons is included as information for others excavating in public-use sites in urban settings. The detailed analysis of the lithic artifacts will be helpful to others dealing with both Historic and Late Prehistoric sites in the area.

Because of the method of deposition of the fill of the fortification trenches, which makes up by far the largest proportion of the total artifact collection, all of the artifacts recovered have been sorted into categories suggesting their original intended use. Wherever the provenience of a particular artifact might have some meaning in interpreting the site, particularly those from the second season that were found outside the east-west trench, its actual location is mentioned and discussed.

\section{CIVILIAN ARTIFACTS}

\section{Ceramics(Susan W. Dial)}

A wealth of cultural information can be derived from an analysis of archaeological ceramics. Ceramic forms and patterns provide insights into traditions, styles and manufacturing skills of early populations. Vessel shapes also are valuable indicators of diet patterns and food preparation techniques (Neely 1989).

Two sets of attributes were used in describing variables of ceramic types represented in this assemblage. Soft paste sherds were examined according to paste and surface color, finish, decoration, hardness and, when discernible, temper and type of manufacture (handmade or wheel-thrown). Hard paste or refined earthenwares, a category encompassing a broad range of factory-made, glazed white wares, are described chiefly by pattern and style.

Munsell color measurements (Munsell Color Company 1975) were made under high, fluorescent lights and generally are expressed as a range of color values to include intermediate hues. Colors of European white wares and decorated wares are described only in arbitrary terms due to the limited range of the available Munsell chart. In both soft and hard paste categories, selected rim sherds $(2 \mathrm{~cm}$ or larger) were measured on bull's-eye, diameter calculator charts to estimate the diameter and percentage of vessel represented, following Joukowsky (1980:187). Although constituent analysis was not attempted, paste and temper in several soft paste groups were compared rudimentarily under a binocular microscope.

\section{Soft Paste Earthenwares}

Soft paste earthenwares, characterized by a soft porous paste and relatively low firing temperatures, include a wide range of decorative styles and types, ranging from crude, handmade utilitarian wares to the highly ornate, tin-glazed majolicas.

\section{Unglazed}

Bone-Tempered Goliad Ware (343 sherds; Fig. $11, \mathrm{a}, \mathrm{b})$

Bone-tempered Goliad ware (Mounger 1959:181) is a hand-modeled pottery attributed to mission Indians of Spanish colonial times, and is widely distributed in Texas mission sites. Because of striking similarities to Late Prehistoric period bone-tempered Leon Plain ware of central and south Texas sites (Suhm and Jelks 1962:95) as well as to Rockport ware of Texas coastal sites, it has been conjectured that Goliad ware may be a cultural descendant of several earlier Texas pottery traditions (Campbell 1962:335; Fox, Bass, and Hester 1976:67; Shafer 1989). The Goliad ware in this collection exhibits great variation in core and surface color, paste texture, tempering and finish.

Color: Surface colors vary from cream to buff to orange and red. Paste colors range from reddish yellow (7.5YR6/6), light reddish brown (5YR6/4), to pinkish gray (7.5YR7/2). In many sherds, cores are dark gray, a common result of incomplete firing (see Discussion section). Exteriors of many sherds are fire-clouded, indicating irregularities in temperatures and the placement of vessels at firing. Others - particularly thick $(11 \mathrm{~mm})$ basal fragments - are completely soot-blackened, suggesting cooking use.

Paste Texture and Hardness: Paste ranges from a relatively fine-grained mix with few inclusions to a pumice like substance studded with white bone bits and resembling particle board. In many of the sherds with gray, immature cores, temper appears black. Hardness is variable, depending upon firing temperatures. Some immature sherds may be scratched with a fingernail, whereas completely fired sherds are more resistant. 


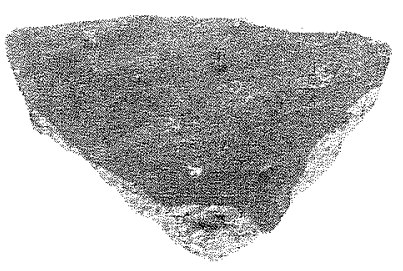

a

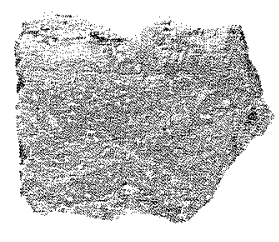

b

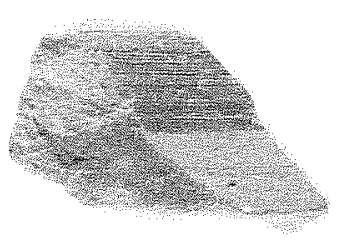

C

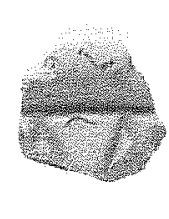

d
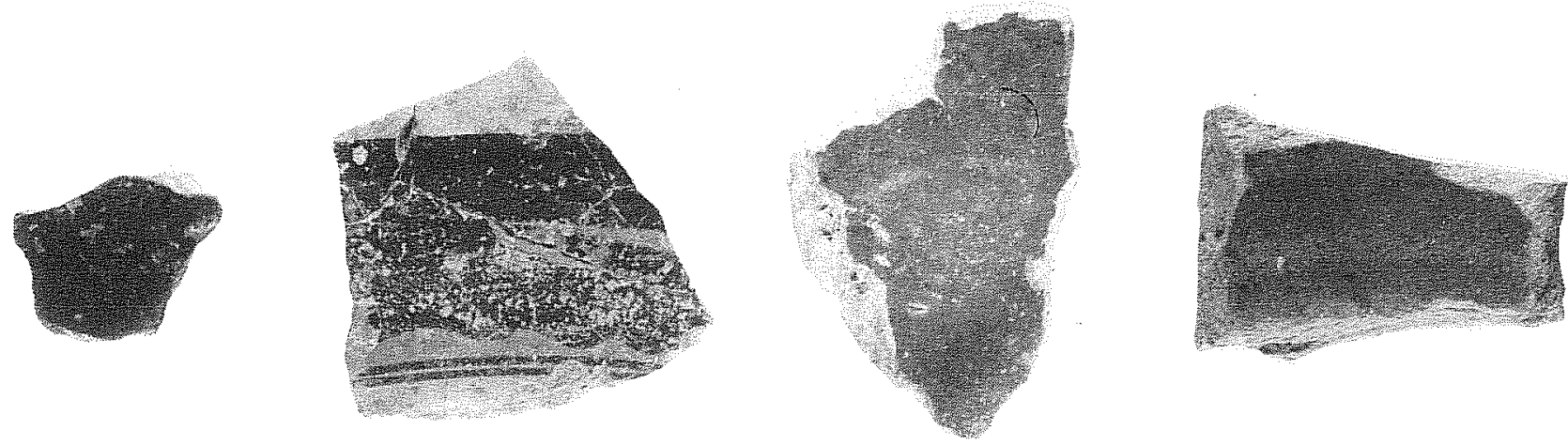

e f

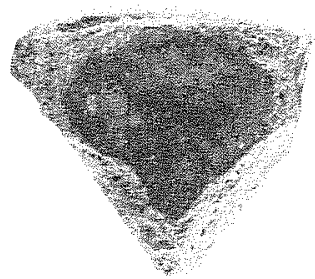

g

h
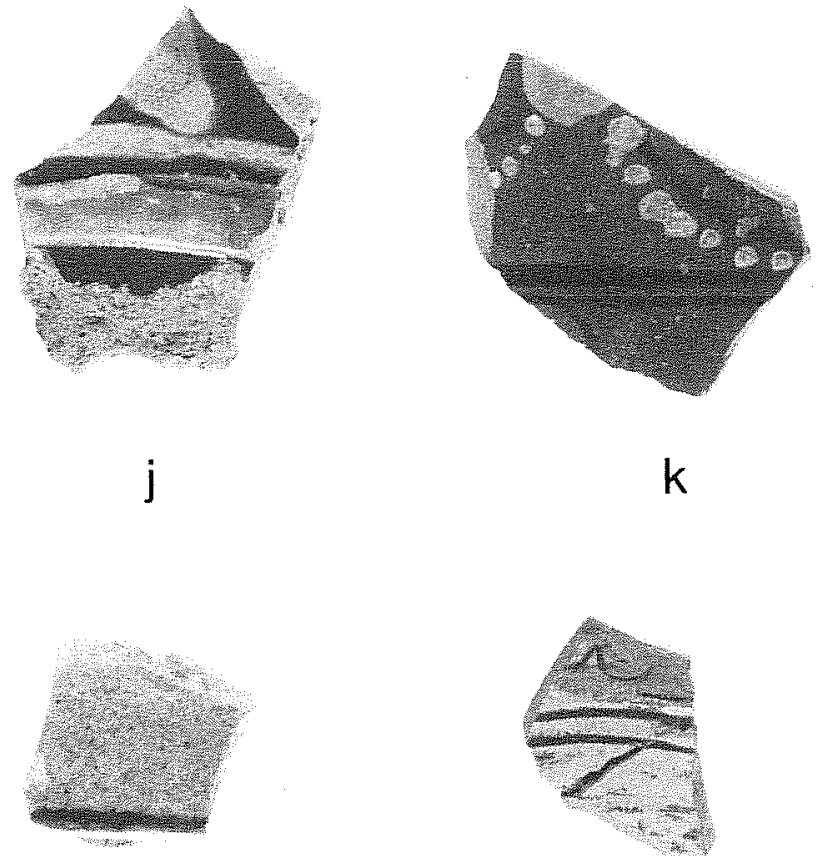

$n$ k

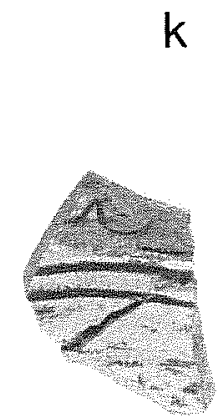

o
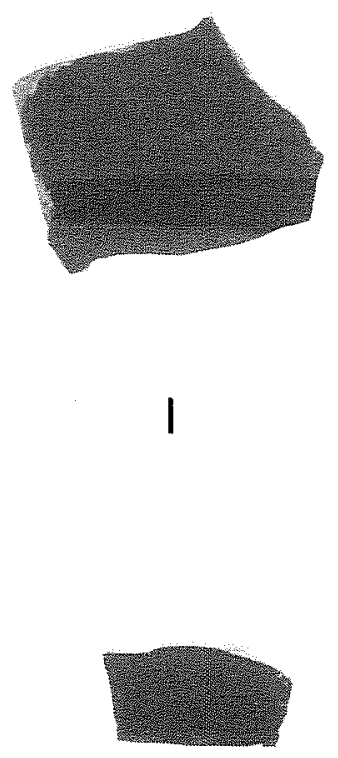

$p$

Figure 11. Unglazed and Lead-Glazed Wares. a, Goliad ware, fine-grained paste; b, Goliad ware, coarse paste; c, wheel-thrown, red-on-pink ware, red rim band; d, orange paste, incised; e, red burnished ware; f, Tonalá burnished ware; g, sandy paste utility ware, gray paste with green glaze; $h$, sandy paste utility ware, orange paste with gold glaze; i, olive jar; j, Galera ware, cream and green decoration; k, Galera ware, brown and cream decoration; 1, red brown ware; $\mathrm{m}$, Tonalá Polychrome; n, decorated yellow-glazed ware; o, incised, decorated ware; p, black lusterware. Shown actual size. 
Finish: Many sherds are well smoothed or burnished. Four exhibit crossed striations, as if brushed or rubbed with a ridged tool, possibly a shell. What appears to be a pinkish red slip on several buff paste sherds apparently is a false or "self-slip" - a change in surface texture and color achieved by drawing water to the surface of the vessel during the smoothing process (Neely 1989). After firing, such vessels may exhibit a different exterior color than paste color.

Blackish brown, mottled streaking on some burnished surfaces appears to be deliberate decoration or painting; perhaps similar to oak bark staining on Oaxacan Rio Blanco pottery (Espejel 1975:83-84). However, the streaks are more likely a phenomenon of the open-firing process.

Two sherds contain asphaltum along their edges, indicating a previous mending process. Asphaltum-mended as well as asphaltumdecorated Goliad ware has been reported at other Texas sites (Mounger 1959:168; Gilmore 1974:117).

Forms Represented: The rim sherds suggest wide bowls (16-17 $\mathrm{mm}$ in diameter of orifice), with lip angled slightly inward. Also represented are large ollas, with a reverse S-shaped neck and rim. Goliad vessels probably served a variety of utilitarian purposes, including cooking, storage, and serving.

Discussion: Goliad ware from other Texas sites has been subjected to a variety of analytical techniques. Sub-groups have been proposed according to decoration (Mounger 1959:163-181); presence of asphaltum, and type and amount of temper (Gilmore 1974b:118-120); and by apparent paste color and temper correlations (Greer 1967:15-16).

The relatively small size of this Goliad ware collection renders statistical analysis meaningless. However, it seems possible to rule out color and paste texture as cultural attributes. Approximately $78 \%$ contain gray black cores, with exterior surfaces of buff, red or gray, a combination indicating incomplete oxidation during firing. In over 50 sherds, cores and exteriors are uniform in color, and tend to be harder, well-smoothed and "clink" when hit against a hard surface, indicating a more uniform and higher firing temperature. Thus a degree of variation in surface and core colors - even within a single sherd - suggests irregularities due to hand-building, open firing, and clay selection, rather than tradition-based cultural preferences.

Further comparisons of large collections of Goliad, Leon Plain and Rockport vessel forms may provide a clearer picture of the derivation of the mission Indian pottery type.

Wheel-Thrown, Red-on-Pink Ware (123 sherds; Fig. 11,c)

Wheel-thrown, red-on-pink wares are composed of a pink to gray, soft, sandy paste which leaves a dusty residue on the hands. Sherds are uniformly small with rounded edges prone to crumbling. A reddish rim band and circular wheel marks are apparent on some. Ivey and Fox (1981:31) have suggested the name Valero ware for this type.

Color: Paste ranges from gray (5YR6/1); red (2.5YR6/6); to pink to reddish yellow (5YR7/3-7/6). Exterior colors vary in slightly darker values of reddish yellow and gray. Rim band color is a thinly applied dark red (0R3/6). The uniform color from core to surface suggests more regulated firing temperatures, perhaps a kiln.

Paste Texture and Hardness: The paste is porous, medium to fine-grained. Under $30 \mathrm{X}$ binocular magnification, some mineral inclusions appear to be gray shell or fossilized shell. Surfaces can be scratched easily with a fingernail.

Finish: Surfaces are smoothed but not polished. Five sherds contain a thinly applied, uniform band of reddish brown on rims. One rim is painted brown.

Forms Represented: Sherds are too small to identify vessel forms. The relatively uniform thickness $(9-11 \mathrm{~mm})$, lack of soot marks (apparent on only two sherds), and porous, soluble nature of the paste suggests that these vessels may have been used for dry storage or serving rather than for cooking or storage of liquids.

Discussion: Dating of this pottery is uncertain. Following the 1976 excavations at the Alamo (Fox, Bass, and Hester 1976:67), it was noted that wheel-thrown pottery of this type appeared in sufficient amounts to suggest local manufacture. This type probably corresponds to Valero ware (Ivey and Fox 1981:31) and Red-on-Orange Ware (Greer 1967:19).

Orange Paste, Incised ( 2 sherds; Fig. 11,d)

Two rim sherds contain an incised design of inverted " $V$ " shape, and a thin, incised line 
circumscribing the rim. The designs are highlighted in a faded red. The soft paste is easily scratched with a fingernail. The sherds are too small to carry analysis any farther.

Color: Paste is reddish yellow (5YR6/6).

Red Burnished Ware (19 sherds; Fig. 11,e)

A glossy, burnished surface on a fine-grained red paste characterizes 19 sherds.

Color: Paste is red (2.5YR5/6).

Forms Represented: With the exception of a single handle fragment, sherds are too small to discern vessel parts.

Discussion: In other sites, varieties of Red Burnished or Red Slipped Burnished Ware are decorated with curvilinear matte designs (Fox, Bass, and Hester 1976:64; Gilmore 1974:63; Schuetz 1969:52). This type of ware may have been brought from the Valley of Mexico to northern Spanish colonies by Indians (Boyd 1974, as cited in Gilmore 1974:63), or by the annual supply train.

Tonalá Burnished (33 sherds; Fig. 11,f)

The Tonala sherds in this collection are distinguished by being thin-walled, slip-painted and burnished to a dull sheen. Several are decorated in black, rust, and orange. No rilling marks are visible; vessels probably were mold-made or hand-thrown.

Color: Paste is gray to buff (7.5YR7/2).

Paste Texture and Hardness: Fine grained and generally homogenous. Surfaces can be scratched with a fingernail, exposing a slightly lighter shade of clay under the burnished exterior.

Finish: Rims and upper body sherds are decorated with bands of black and rust, interspersed with rust-colored wavy lines. One sherd - the ring-footed base of a toy sized bowl - contains more elaborate rust and black geometric scroll designs in the interior. This may be a form of the encaje, or lace, design typical of Tonalá wares.

Forms Represented: A toy bowl (approximately 21 mm diameter at base); a small jug or olla (approximately $33 \mathrm{~mm}$ diameter at orifice), and a jar or bowl, are discernible.
Discussion: Aromatic Tonalá clay has been the subject of much folklore. In the Tonala region of Jalisco, Mexico, the earth-scented clay was thought to have beneficial qualities if ingested (Charlton and Katz 1979:52). Contemporary Tonalá potters, carrying on a tradition that dates at least to the late Spanish colonial period (Katz 1977:52), shape clay in molds, cover vessels with an aromatic slip of light beige clay, or "barro de olor", and decorate and burnish the vessels before firing (Diaz 1966:143-147). Today's pottery is considered a poor imitation of its Spanish colonial counterpart; vessels are thicker-walled, and clay apparently is of poorer quality with little or no fragrance (Espejel 1975:169).

Tonalá ware is noted for its unusual forms and is widely distributed in Spanish colonial sites (Fox 1986:11; Schuet 1969:52). This ceramic type may correspond to Gilmore's (1974:63) Polychrome Burnished, Style 2. In Florida, it is called Guadalajara Polychrome (Deagan 1987:44-46). It has also previously been referred to as Aztec IV Polychrome (Deagan 1987:45) and Tonalá Bruñida ware (Charlton and Katz 1979).

Glazed

\section{Lead Glazed}

Lead-glazed earthenwares usually comprise a large proportion of the ceramic inventory in Spanish colonial sites and clearly served an important purpose to early settlers. Information on dating and manufacturing areas of lead glazed-wares is sparse. Indications are that lead-glazed were introduced into the Mexico City area by post-conquest (ca. 1520) Spanish artisans, who taught their trade to Indian laborers who, in turn, applied lead glaze to their traditional wares (Lister and Lister 1974:25).

Lead-glazed sherds in this collection have been divided, following Fox (1974:55), into three categories: sandy paste utility ware, fine-textured paste, and olive jars. Several sub-varieties also are included.

Sandy Paste Utility Wares (220 sherds; Fig. 11,g,h)

Like Goliad ware, sandy paste utility vessels generally are crudely made and notable chiefly for their diversity, varying widely in color, thickness, and paste texture. Many sherds are blackened or have gray, immature cores, with glazed exteriors 
ranging in green to brown tones. Others range from pinkish red to orange paste with exteriors varying from brown to gold tones. Color of glaze and core apparently varies according to firing temperature and atmosphere.

Paste Texture and Hardness: Texture is generally coarse, pumice-like or sandy. Sherds leave a sandy residue on hands. Unglazed exterior surfaces can be scratched with a steel-tipped tool.

Mode of Manufacture: Although deep, circular wheel marks are visible on some basal sherds, it is possible some vessels were handmade. Lead glaze is thinly applied, predominantly on interiors and overlapping rims.

Forms Represented: Ollas (approximately $170 \mathrm{~mm}$ at orifice); thick bowls with rims angled inward to a rounded lip; and jars are represented. With their impervious, lead-glazed interiors, vessels of this type probably were useful for cooking and storage of liquids.

Color and Variability: Sherds recovered during the lunette trench excavations in 1988 were sorted by core and exterior colors, in an attempt to establish co-variance with firing conditions. Assignment to groups by exterior color was arbitrary, due to color variation within individual sherds and differences in glaze thickness. The resultant groups are not intended for use in statistical analysis. Within the continuum, however, it is possible to trace certain patterns in development in core color and glaze.

Green Tones ( 52 sherds) - Core color ranges from light gray (10YR7/1) to very dark grayish brown $(2.5 \mathrm{Y} 3 / 2)$ in core centers. Glazed exteriors are olive (5Y4/3-5/4) to olive brown (2.5Y4/4). Sherds of this group probably represent the lowest firing temperatures.

Brown/Green Tones (21 sherds) - Core color is very dark grayish brown (2.5Y3/2); glazed exterior is dark olive (5Y3/3) to dark yellowish brown (10YR3/4). Sherds of this group also are incompletely fired.

Brown Tones ( 43 sherds) - Core color ranges from very dark grayish brown (2.5Y3/2) to strong brown (5YR7/4). This group is partly composed of dark cored, thicker sherds, as well as thinner sherds with a red paste uniform from core to exterior, suggesting a more complete firing.
Gold Tones (37 sherds) - Core is reddish yellow (5YR7/6); exterior is light olive yellow (2.5Y5/6) to olive yellow (2.5Y6/8) with some green splotches. This group may represent highest firing temperatures and mature cores. Variations in exterior color are due to pigments added to the glaze, or minerals in the lead glaze reacting to temperature. Extremely high temperatures seem to produce gold brown glazed surfaces and a red orange paste.

Discussion: Sandy paste utility ware has been found in large quantities in many Spanish colonial sites. Gilmore (1974:116) speculates that certain lead glazed wares may have been produced at the missions. It would seem illogical to import sandy paste utility wares over long distances by pack trains, particularly given their crude, heavy and poorly fired quality. As yet, however, there is no archaeological or archival evidence for the manufacture of lead-glazed pottery in the area.

Olive Jars (9 sherds; Fig. 11,i)

Olive jars are widely distributed in Spanish colonial sites in Florida, Texas and Mexico. The large vessels may have carried olives or olive oil from Spain and may have been recycled by New World settlers and Indians to transport or store liquids (Goggin 1964:256-293).

Pinkish white (5YR8/2-8/3) paste is hard (resistant to steel tool) and compact. One sherd contains a thick, ring-mouth rim, constricted at the neck and flaring outward at the body. Interior surface is creamy yellow white to pale yellow $(2.5 \mathrm{Y} 8 / 2)$; exterior is unglazed. Estimated diameter of the jar mouth is $80-120 \mathrm{~mm}$. This sherd may represent Goggin's egg-shaped Middle Style vessel or one of the many Late Style vessels. Dating is uncertain (before 1600-1840).

Another rim sherd is flared, contains no lip and is thinner $(7 \mathrm{~mm})$. The interior is coated with opaque, pale yellow (2.5Y8/4) overlapping the rim. Circular wheel marks are visible on the interior. Two sherds are unglazed; one is a body sherd, the other is a rim sherd from a smaller vessel, approximately $60-70 \mathrm{~mm}$ in diameter at the mouth.

The paste is porous with white inclusions, and leaves a sandy residue on the hands. Paste is light reddish brown to light red (2.5 YR6/4-6/6). All are body sherds. One has a heavy matte coating of forest green on the interior and creamy white (2.5Y8/2) on the exterior; a second is coated in light gray to pale yellow $(2.5 \mathrm{Y} 7 / 2-7 / 4)$ on the interior and white $(2.5 Y 8 / 2)$ on the exterior. Three others have a coating of dull gray on one or both sides. This 
group may correspond to Burnett's Group B (1974:62).

Fine-textured Paste

Polychrome Decorated Galera (362 sherds; Fig. $11, \mathrm{j}, \mathrm{k})$

Similar polychrome decorated Galera sherds have been found in Spanish colonial mission and presidio sites throughout the Southwest. Referred to in this context as Galera ware (following Fox 1986:111), this ceramic type probably corresponds to Decorated Orange ware (Fox 1974:57-59), Decorated Lead Glaze wares (Greer 1967:23-28), and West Mexico Polychrome (Schuetz 1969:50-51). Sherds are thin walled (2-4 mm), gold brown to reddish brown in general appearance with painted designs in cream, brown and green.

Paste Texture and Hardness: Paste is light reddish brown (2.5YR6/4), with white and brown mineral inclusions speckled throughout the otherwise fine-grained paste. Unglazed surfaces can be scratched with a steel tool. Glaze appears clear to brownish green, and has been applied thinly and unevenly, creating bubbled or pitted surfaces in some areas. Glaze covers the interior only on some sherds.

Mode of Manufacture: Wheel-made or mold-made is the common mode of manufacture, although some, such as chocolateras, or chocolate pots, may be of composite manufacture. A crude joint is visible on the inside shoulder of one sherd.

Forms Represented: Included are jars with rounded lips (approximately $130 \mathrm{~mm}$ in diameter at the mouth); chocolateras, and deep plates or bowls. Several rim sherds are outwardly beveled. A variety of handles, including the strap variety, was recovered.

Color and Variability: Raised dots, concentric swirls, bands and geometric and floral designs predominate; many are partially overpainted in a darker color, such as olive green over cream. Other colors used are light green, brown and brownish black.

Comments: Similar wares continue to be made in Jalisco (Fox 1974:57).
Red Brown Ware (37 sherds; Fig. 11,1)

Similar in paste and color to Galera ware, red brown sherd are usually thick-walled, deep plates or bowls. Glaze is thick and glossy, covering brown, linear designs.

Paste Texture and Hardness: The paste is generally fine textured with a scattering of small, white inclusions. The color is red to red brown (2.5YR5/6). Unglazed surfaces can be scratched with a steel-tipped tool.

Color and Variability: The glaze color appears to be brown to greenish brown, creating a rich amber surface over the red paste. Application is thick, and is generally applied to interiors, overlapping rims.

Decoration: Although the complete pattern is not discernible, the design appears to be interlocking linear arcs in brown black.

Forms Represented: Deep plates or shallow bowls have flat bases similar to the structure of French faience ware.

Comments: The group probably corresponds to Guadalajara ware identified by Schuetz (1969:51) and Red Brown ware (Fox 1974:59; Fox, Bass and Hester 1976:64). Similar wares are made today in the Jalisco region (Fox 1974:57).

Tonalá Polychrome (7 sherds; Fig. 11,m)

A creamy yellow slip covers pink/buff paste on the Tonalá Polychrome sherds. Sherds are too small for identification of design patterns. Decorative colors used are green, brown and black with overlapping green and brown rim bands. The glaze is sloppily applied and flakes easily. Barnes (1980:102) suggests that this ware was made in western Mexico and distributed to northwestern New Spain between 1780 and 1830. These dates probably also hold true for Texas.

\section{Miscellaneous Lead Glazed Wares}

Decorated Yellow-Glazed, Cream Paste (9 sherds; Fig. 11,n)

A yellowish glaze covers dark brown painted geometric designs on the interiors of nine sherds; exteriors are peach colored, unglazed. The paste is gray to cream in color, compact with scattered tiny 
inclusions. Similar sherds have been excavated at Mission Concepción (Scurlock and Fox 1977).

Incised, Decorated Red Paste (5 sherds; Fig. 11,0)

Interior surfaces are slipped in creamy pinkish tan, painted with olive green and red brown designs and incised with linear designs revealing the red body beneath the glaze. The paste is red (2.5YR5/4-5/6).

Similar sherds with this graffito-type decoration have been found elsewhere on the Alamo grounds and at the Spanish Governor's Palace site in downtown San Antonio (Fox 1977a:14). The sherds recovered so far in San Antonio are too small to project vessel form.

Crenelated Edge, Red Paste (1 sherd)

An opaque, creamy beige glaze covers the sherd interior, overlapping the crenelated rim to form an exterior band. The paste is red (2.5YR5/6).

Black Lusterware (7 sherds; Fig. 11,p)

Black lusterware sherds are covered with an iridescent, glassy brownish black glaze, which flakes off easily from the edge and has become worn and thin in some areas. The paste is gray (5YR6/1) with small dark inclusions. One sherd has a red paste. Black lusterware has been recovered at other area mission sites and is attributed to the Puebla area of Mexico (Schuetz 1969:52).

\section{Tin Glazed}

The process of adding tin to lead glazes to achieve a whitish, opaque, glossy surface apparently originated in the Middle East some 2000 years ago (Caywood 1950:79, as cited in Tunnell 1966:1). Tin-glazed ceramics, including majolica, delft, and French faience, generally are composed of a soft porous paste and decorated with ornate, brightly colored designs painted over or within the highly fired enamel glaze. Vessels are, with few exceptions, wheel-thrown and kiln-fired. Two types of tin-glazed earthenwares have been found in excavations at the Alamo: Mexican majolica and French faience.

\section{Mexican Majolica}

Some 359 sherds of majolica were recovered during the two seasons. Within this collection gradual changes in style, color and craftsmanship can be traced. Represented are samples of early blue and white patterns, probably produced during the peak years of the Puebla potteries, as well as later, less finely crafted varieties marketed in competition with European white wares (Tunnell 1967:26; Fox 1988).

Majolica sherds were sorted according to paste color, style and color of decoration. Sources used in identification include Lister and Lister (1975:25-48), and type collections at the CAR-UTSA laboratory.

Most of the decorated sherds were very small $(1-2 \mathrm{~cm})$ making pattern description difficult. Identified types are presented in relative chronological order, beginning with the earliest.

Puebla Polychrome (11 sherds; Fig. 12,a)

Distinctive blue and black geometric designs characterize this early majolica type, Puebla Polychrome.

Paste Color: Paste color ranges from pinkish white (7.5YR8/2 to 5YR8/1). The glaze is a thick, glossy, grayish white, crazed and pockmarked in some areas. Tiny blue specks of color are scattered on exterior surfaces.

Design: Thin black to black brown, concentric circular designs are cobweblike in appearance on some sherds, and are interspersed with dark, cobalt blue design elements.

Forms Represented: One small basal sherd, containing part of a foot ring, is probably from a deep plate. The other sherds are too small to project forms.

Discussion: Puebla Polychrome has been recovered in early Spanish colonial sites, including the Spanish Governor's Palace of San Antonio (Fox 1977:14) and Mission Concepción (Scurlock and Fox 1977:Fig. 24,d). It dates from approximately 1650 to 1725 .

San Elizario (13 sherds; Fig. 12,b)

The typical motif is gray blue rim bands framed by thin greenish brown lines. Gray blue pendant petals or dots are crudely attached to the lower band. Sherds in other collections contain central interior designs of birds and floral elements (Tunnell 1966:8). 


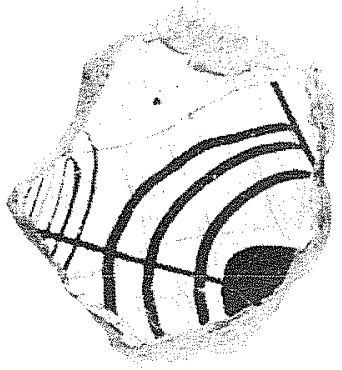

a

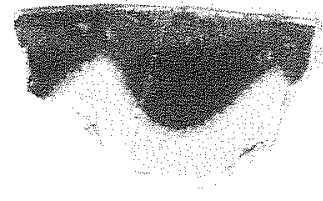

f
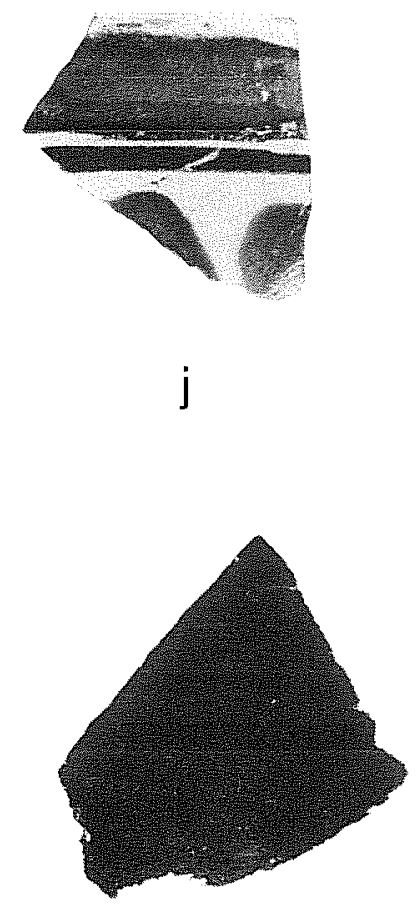

I

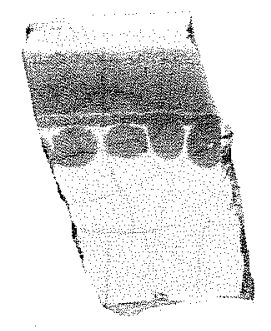

b

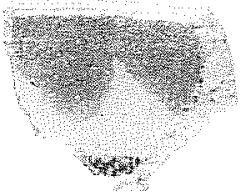

g

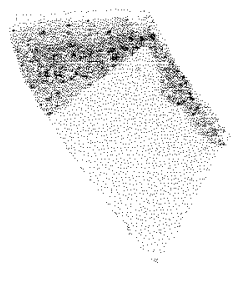

k

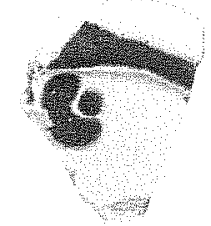

C

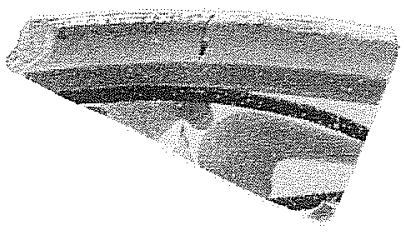

h
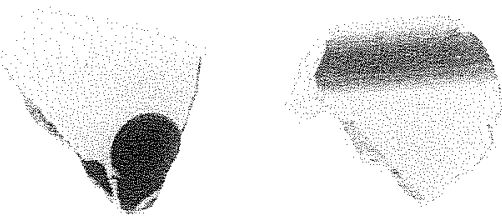

e

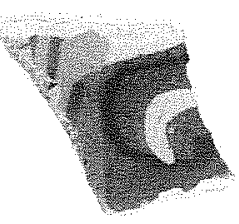

i

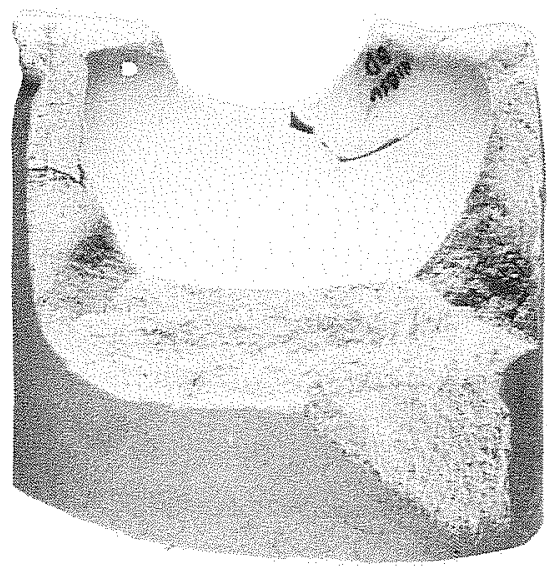

m

$\mathrm{n}$

Figure 12. Tin-Glazed Wares. a, Puebla Polychrome; b, San Elizario Polychrome; c, Blue-on-White, Style A; d, Blue-on-White, Style B; e, Huejotzingo Blue-on-White; f, Huejotzingo blue scalloped; g, Huejotzingo green scalloped with brown line; h, Guanajuato, green, rust, and brown; i, Monterey Polychrome; j, Mexico City type; $\mathrm{k}$, unclassified type, yellow tan-on-cream; 1 , Rouen-type faience; $\mathbf{m}$, orange-decorated faience; $\mathbf{n}$, faience rouge pot. Shown actual size. 
Paste Color: Two different paste types are included in this collection: red $(2.5 \mathrm{YR} 5 / 6)$, and gray white (7.5YR8/2). These date from approximately 1750 to 1850 (Deagan 1987:86).

Discussion: First described from Texas and northern Mexico sites by Rex Gerald (1968:45), this type has also been excavated in Florida, where Hale Smith (1965:86) called it Playa Polychrome. In the southwest, Snow identifies the same pattern as Puebla Polychrome II.

\section{Blue-on-White (52 sherds)}

Sherds of the blue-on-white group were too small to identify conclusively and are grouped according to similarities in design and color. Many probably could be categorized as Puebla Blue-on-White.

Style A (Fig. 12,c): Rims are banded in blue; designs include clusters of dots, and dots within dots in powder blue, slate blue, and deep cobalt. Patterns have a paisleylike appearance and resemble Tunnell's (1966:7) Style 3. The paste color is gray-white, creating an overall faded appearance.

Style B (Fig. 12,d): Colors are deep cobalt blue on stark white to bluish white background. Glaze is generally thick and glossy. Design elements, some of which are raised, appear to be budlike flowers, daisylike flower petals, and bird tails. Paste color is gray-pink.

Style C: A hard terra cotta red paste distinguishes this blue-on-white group. Sherds are too small to discern patterns.

\section{Huejotzingo (18 sherds; Fig. 12,e,f,g)}

A straight or scalloped band in blue or light olive green encircles the rims of the Huejotzingo sherds. The paste ranges from gray to pink. Nine sherds have a straight blue band; three have a wavy band, one of which is on a scalloped-edged rim. Four have a green-scalloped band, one of which has a thin brown line parallel to the rim and five-eighths of an inch below. The glaze on green-banded sherds is tinged yellowish green. Tunnell (1966:8) speculates that plates of this style were produced in imitation of English edgeware plates, popular in the late 18th century. This ware, however, appears to have been made throughout the 18th century (Barnes and May 1972:10; Goggin 1968:195).
Guanajuato (79 sherds; Fig. 12,h)

Guanajuato sherds have a distinctive deep red, terra cotta colored paste, with design colors in green, rust, and dark brown in a greenish tinted glaze.

Paste Color: The paste color is pink (5YR7/4) to red $(2.5$ YR5/6).

Finish: The glaze appears sparse and uneven in some a sign of decreasing quality in this late (post-1820) type. Design elements generally are less sharply executed than blue-and-white patterns; included are borders of dark green and rust petals and leaves and bands in green, brown and rust. Some rim patterns appear to be a green tone rendition of the San Elizario band and petal motif. Two sherds combine yellow and gold colors, more typical of Aranama style, into the Guanajuato pattern.

Forms Represented: A footed bowl (approximately $210 \mathrm{~mm}$ in diameter) is discernible from this collection. McKenzie (1989:3) also has recorded a cup form with the same design excavated at Mission San Juan Capistrano and elsewhere at the Alamo as well as from the plaza excavations.

\section{Unclassified Polychromes (35 sherds)}

Sixteen sherds have red to gray paste with olive green designs on a greenish cream background. The sherds are too small to identify the designs. Forms represented are primarily deep plates and cups or bowls.

Fifteen sherds have pink to cream paste and bear traces of yellow bands outlined in brown or orange and yellow designs. Forms represented are cups and plates. These sherds are probably portions of polychrome patterns of the Aranama tradition such as Monterey Polychrome (Fig. 12,i), dating about 1790 to 1830, San Diego Polychrome, dating about 1770 to 1800 , and Tucson Polychrome, dating about 1820 to 1850 (Barnes and May 1972).

A rim sherd (Fig. 12,j) from a bowl (actually two sherds mended into one) has a red paste with design consisting of a wide green band below which are two black lines. The body of the bowl bears a petaled green design. The rim sherd appears to be a Mexico City type identified by Lister and Lister (1974:Fig. $11, \mathrm{j})$ as being made in the 19th century.

One tiny sherd with pink paste is decorated with bright yellow and powder blue, which ordinarily would suggest Tumacacori Polychrome. However, unlike that type, the reverse or inside of the vessel 
has a cream glaze rather than blue. Another similarly colored sherd (also consisting of two fragments), not from the same vessel, has only blue decoration on a deep cream background. The paste is dark pinkish red typical of early 19th century majolicas.

One thin rim sherd (Fig. 12,k) with cream paste has yellow tan decoration which may be a scalloped band similar to the designs on Huejotzingo. The fragment is too small to determine the exact pattern. The background color is cream similar to that of the various polychromes described previously.

\section{Undecorated (160 sherds)}

Undecorated majolica sherds contain red, medium pink or gray-to-grayish pink paste. The glazes vary from gray white to pink white. Vessels represented include deep plates, small bowls and cups. Some of these sherds probably come from vessels that bear decoration elsewhere on them, but a number appear to be from undecorated vessels. Lister and Lister (1974:30) have observed that plain, white majolica was made "throughout the Mexican continuum."

\section{French Faience}

Tin-glazed faience chiefly is identified by decorative pattern, glaze color and texture. The glaze tends to feather or flake inward from the edges of sherds, and some white-glazed surfaces have a bluish cast (Fox 1988).

\section{Rouen Type (1 sherd; Fig. 12,1)}

A body sherd from a bowl-shaped object has a pinkish red body covered on the outside with a dark brown lead glaze and on the inside with a bluish-tinted white glaze. The paste is pink (7.5YR8/4).

\section{Yellow Orange Decorated Type (1 sherd; Fig. 12,m)}

A very thin $(2 \mathrm{~mm})$ red-bodied sherd appears to be from a small cup. The shiny white glaze is decorated with small eight-pointed yellow orange stars. Somewhat similar sherds have been recovered from the first site of Presidio Ahumada (41 CH 57) in Chambers County, Texas, which was in existence from 1856 to 1866.
Rouge Pot ( 3 sherds; Fig. 12,n)

A small heavy cylindrical jar mended from three sherds has been identified as a rouge pot. It is similar to jars found at other Spanish colonial sites in San Antonio, New Orleans and Puerto Rico (Fox 1986:111).

Surfaces are covered in a milky blue green glaze on the exterior and white on the interior. The glaze feathers at the edges and is worn and dull in some areas. The paste is pinkish white (7.5YR8/2-8/4). The texture is hard and compact. The jar is $36 \mathrm{~mm}$ in height and $51 \mathrm{~mm}$ in diameter, with a wall thickness of $11 \mathrm{~mm}$. It once had a ring foot and an everted rim, which have been broken off.

\section{Hard Paste Earthenwares}

Refined or hard paste earthenware includes a wide variety of plain and decorated English whitewares. Backmarks and patterns in some cases help establish time and place of manufacture. It is likely that many of the vessels represented in this collection were produced in the Staffordshire area in the early 1800 s for export to the United States.

Whitewares

Undecorated (544 sherds)

Whiteware is used herein to describe a hard, cream to gray white paste earthenware coated with a bluish to clear glaze. Many sherds in this group may be the undecorated portions of hand painted or transfer-printed wares. For the most part, these sherds represent simple, domestic tablewares cups, saucers, deep plates, and some hollowware vessels. Of the 529 sherds, many are less than $2 \mathrm{~mm}$ in size.

Undecorated sherds are divided roughly according to glaze and paste color, time sensitive attributes which may reflect changes in English ceramic technology. The manufacture of clear-glazed, cream paste creamware in the $1760 \mathrm{~s}$ (Fox 1988) was followed in the 19th century by the development of pearlware, a cream paste earthenware coated with a cobalt-tinted glaze to whiten its appearance (Towner 1978:73).

Some sherds in the clear glaze, white paste category may be considered semi porcelain or heavy hotelware, which is thicker and contains harder paste with partially fused grains. Assignment to 
groups by color of glaze and paste is arbitrary due to the subtle gradations of tint. The following subdivisions are intended only to reflect the continuum in color changes.

Cream Color: One group of sherds contains a cream to beige paste and clear to slightly green glaze, creating a pale brownish cream appearance overall. Sherds are uniformly thin. The glaze is lightly crazed and spackled in some areas. Vessels represented include thin cups, saucers, and what may be a small bowl with a double-rimmed base. This group may be creamware.

Blue-to-Blue Green Tint: Some sherds are coated in a clear, bluish to green glaze, particularly evident where thickly accumulated at base footings. Sherds of this group may be pearlware. Vessels represented include thin cups, saucers, thicker-walled bowls, and deep plates with sturdy, rounded foot rings.

Other: Sherds remaining include a variety of gray-white to white fragments, many very small. Glaze on some is clear with a scattering of blue specks. Several are heavy, thick ironstone containing trademarks of American potteries (see Makers' Marks section). These sherds, dating in the $1860 \mathrm{~s}$ and later, are undoubtedly related to the town's use of the area as a public plaza around the turn of the century.

\section{Decorated}

Edgeware (67 sherds; Fig. 13,a-j)

Edgeware sherds are generally thick pearlware or white ware with blue or green rims press molded in a variety of shell, feather or leaf designs. The predominant form is a deep plate or shallow bowl. Edgeware is widely distributed in early Texas sites, such as Washington-on-the-Brazos (Davis and Corbin 1967), La Villita (Fox 1986) and San Juan Capistrano (Schuetz 1969). Dating ranges from 1780 to 1900 (Gilmore 1986:79).

Terminology in describing edgeware is often imprecise, due to the many subtle variations in pressed rim designs and application of color. Description is complicated further by interchangeable use of such terms as shell edge, feather edge, scalloped edge and feathered paint application. Moir (n.d.) presents a rudimentary typology for edgeware and suggests temporally sensitive attributes. Further refining of terminology is needed in order to facilitate adequate analysis and comparisons.

Eighteen possible different rim designs ( 42 blue and 25 green) are present on the edgeware sherds. These include examples of the more elaborate leaf, bead, and repousse designs, as well as the more common rims with impressed, parallel wavy or straight lines perpendicular to the lip. Lip edges are scalloped in as many as seven size gradations; lips on some sherds are straight. Six sherds reflect the apparent later technique of applying a straight-edged band of color over the impressed design, rather than hand painting color into the design itself, creating an uneven lower edge.

Of the 67 edgeware sherds, only one has a straight, noncockled edge and lightly incised design. Moir (n.d.) dates this particular design to the 1840-1860 period. Since this sherd came from the backdirt during the excavation of the south end of the lunette, and since the fabric of the sherd appears to be ironstone, that date range seems plausible.

Slipware (125 sherds; Fig. 13,k-r)

Annularware, slipware, banded slip, dipped ware and mochaware are terms used to describe varieties of slipped, decorated white ware produced for the English working class from the 1700 s to early 1800 s (Bemrose 1952:9). Although a variety of patterns and colors were utilized, the basic technique entailed the repeated application of colored slip bands onto an earthenware body. The slip - a clay mixture of cream consistency - was applied by dipping or brushed on as the vessel was turned on a wheel.

Creamware and pearlware carried the earliest slip decorations; after the 1830s, white earthenware and stoneware were used. Slipware reached peak popularity in Texas during the 1840s and 1850s according to Gilmore (1986:79). A variety of slip patterns are represented in this collection.

Impressed designs are represented by rouletted herringbone, straight grooves, and scallops interspersed with bands of color, primarily at or just under the rim.

Dendritic or tree-like patterns are created when drops of mocha "tea" - an infusion of hops, stale urine, turpentine, and other ingredients - are dripped onto the slipped surface (Van Rensselaer 1966:337-349).

Marbleized patterns are the result of the scrolling together of two or more colors into a trailing "worm"-like design, a dripped and "combed" design or a "cat's eye" design of agate-like, shaded circles. 


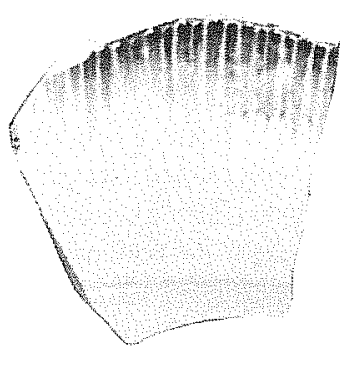

a

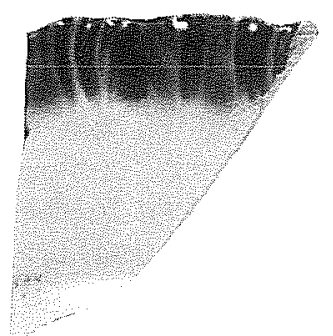

e

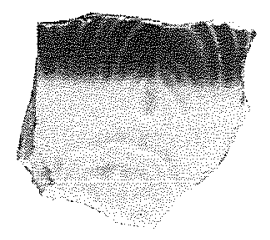

i

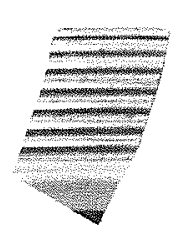

m

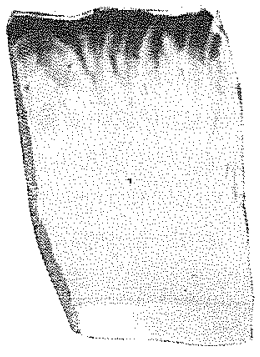

b
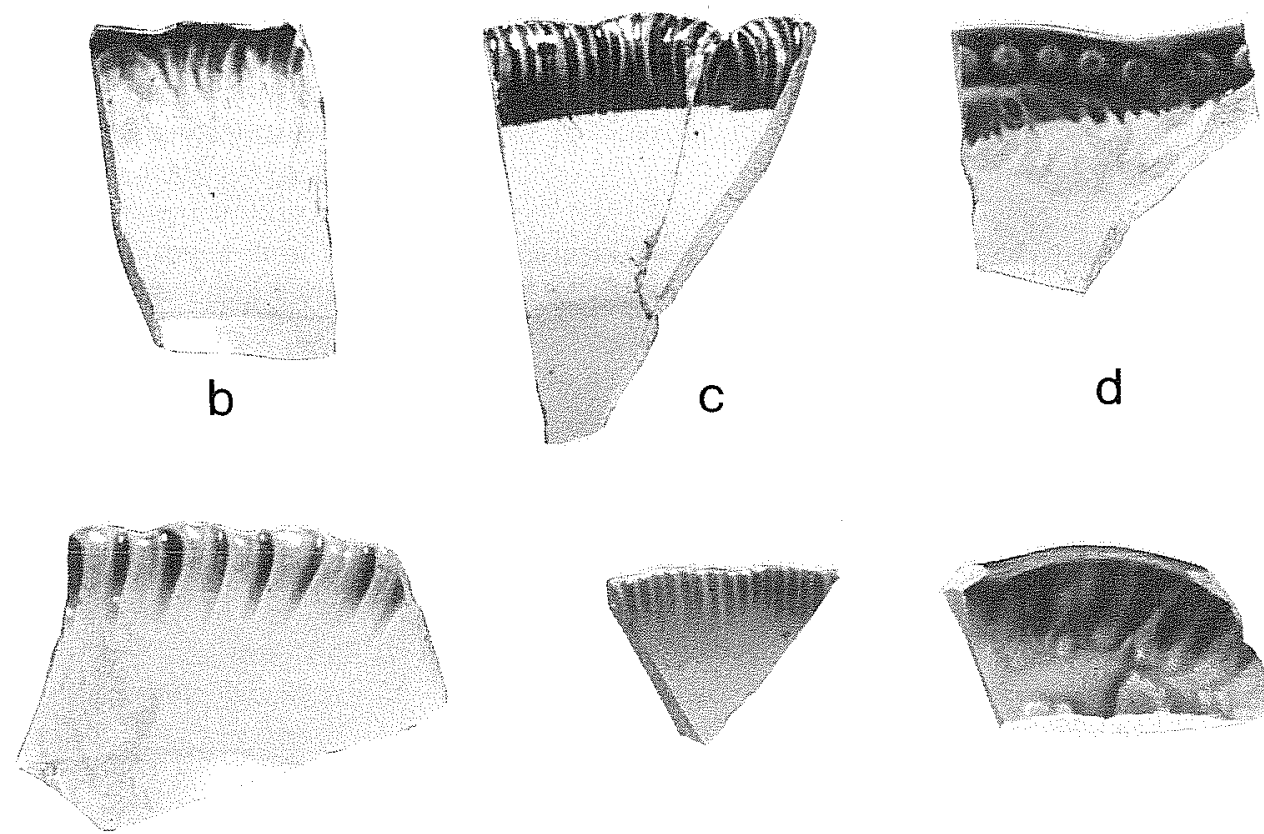

f
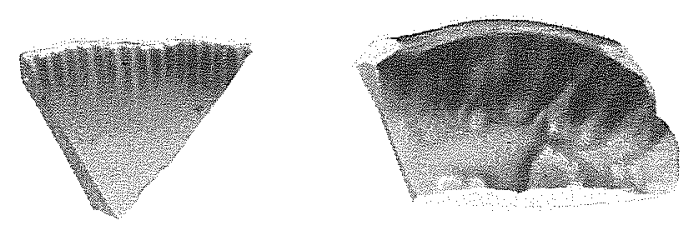

g

h

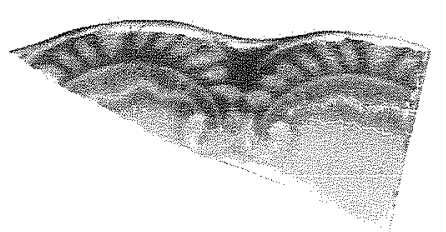

j

$\mathrm{k}$
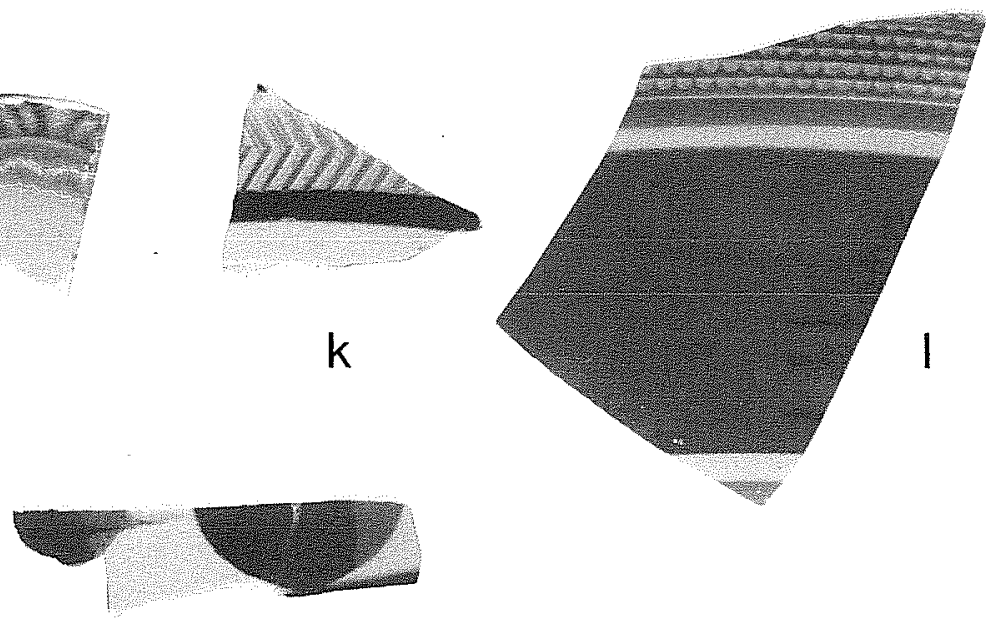

$\mathrm{O}$
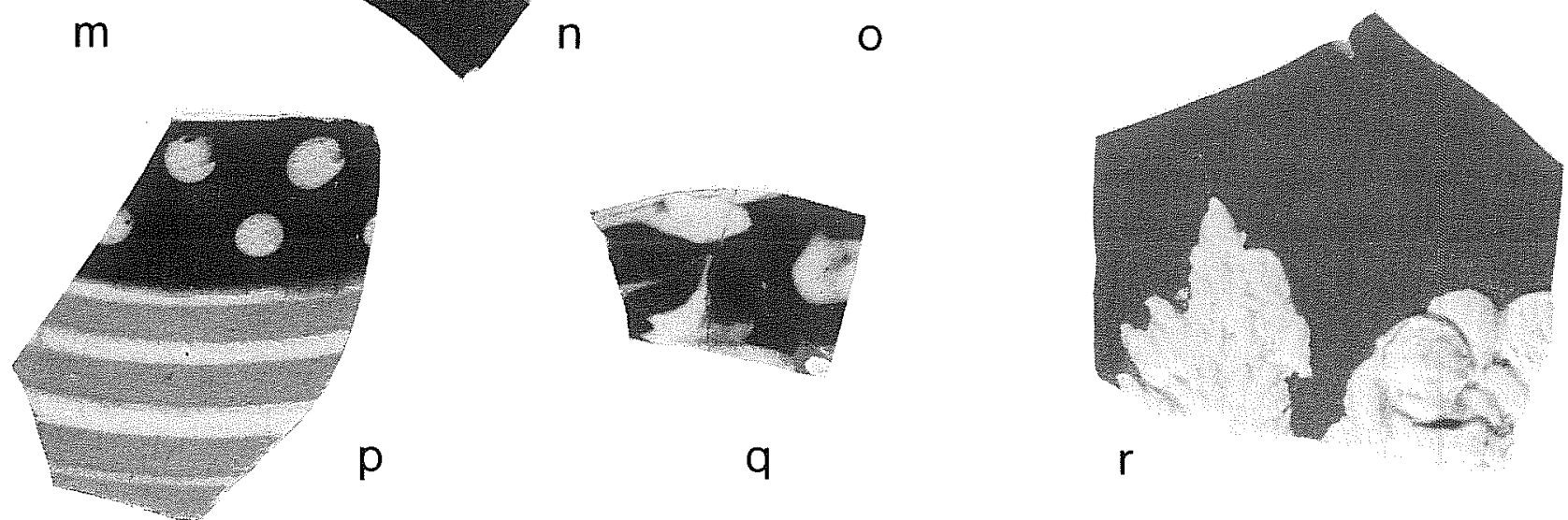

Figure 13. Decorated Whitewares. a-d, blue edgeware; e-j, green edgeware; $k$, slipware, impressed design; 1 , slipware, impressed and dendritic decoration; $m$, slipware, impressed rim band; $n$, slipware, dendritic decoration; o, slipware, cat's-eye design; p, slipware, bands and dots; q, slipware, marbleized slip; r, slipware, raised design. Shown actual size. 
Other patterns include small and large dots interspersed with a series of colored bands. On one rim sherd, a buff-colored wavy band is irregularly painted over a wide black band. Predominant colors are cream, white, rust, brown, gold, black, green, and various shades of blue.

Reconstructed slipware vessels from other sites suggest that vessels were decorated in certain orders of patterns, with impressed designs used typically around the rim, a wide band of decorative dots, dendritic patterns or marbelized designs arrayed as the central element, and bands of color in varying widths interspersed over the body.

Two atypical sherds slipped in grayish moss green contain raised white figures. One sherd contains a classical depiction of several cherublike children (Fig. 13,r). On another sherd, a white lotus or lilylike flower is accented in pink.

Slipware vessels represented are predominantly hollow ware: bowls, pitchers, and possibly mugs. One sherd contains an applied handle base. Slipware tankards and measuring jugs were popular in 18th-century English taverns (Bemrose 1952).

\section{Hand-Painted (186 sherds; Fig. 14)}

Hand-painted underglaze whitewares were popular import items in Texas in the early 1800 s. Brightly colored florals and geometrics are dominant motifs, rendered for the most part in a crude or impressionistic style.

In this collection, small sherd size and similarities in color and decoration make identification of distinct patterns difficult. As many as 20 different patterns may be represented. Particularly numerous are sherds in a blue and white Oriental floral motif consisting of a dark blue rim band, blue leaves, and blue dots arrayed near stems. A small ( 40 to $50 \mathrm{~mm}$ diameter at base) cup fragment has a v-shaped mark in blue on the bottom. Sherds of this pattern have been recovered in other area sites (Schuetz 1969) and have been attributed to the Adams factory, ca. 1804 or later. Blue and white patterns are considered to be the earliest of the hand-painted wares (Gilmore 1986:80). A variation of this style includes pale gold fernlike leaves within a blue and white floral design. The lip edge is covered in blue.

Another hand-painted style frequently recovered in Texas sites (Davis and Corbin 1967:23-25; Schuetz 1969) contains a wide floral border of wine pink, star-shaped flowers, pointed green leaves, and black stems. A blue band encircles the rim.
Other patterns combine gray green feathery leaves, olive green dots, budlike, rust orange flowers, and double rim bands in brown; wide green leaves on squiggly black stems; gold brown buds or stubby leaves on curving brown stems, banded on midrim and below the lip in blue and light brown; pink mauve stylized roses with green leaves, with rims banded inpink. Forms represented include thin cups, saucers (ca. $130 \mathrm{~mm}$ in diameter), small bowls, and deep plates.

In other Texas sites, hand-painted patterns identical to those found here have been identified erroneously as "Gaudy Dutch." A distinctly colored, Oriental style with blue under glaze decoration painted overglaze with bright red, yellow, orange, pink, and green (Anne Y. Wolfe, Winterthur Museum, personal communication; Kane 1947), the Gaudy Dutch style is found more frequently in the Pennsylvania Dutch area. It is seldom found in Texas.

\section{Transfer Printed (179 sherds; Fig. 15,a-l)}

The specialized technique of transfer printing on earthenware was developed in the mid-eighteenth century in England. Designs engraved on copper plates were impressed on a special paper and then "transferred" to the earthenware biscuit, which was glazed and fired in a glost oven (Coysh 1970:7).

Thousands of different transfer patterns were produced, and North America was the target for much of the production. Earliest designs, printed in black and dark blue on creamware or pearlware, tended to be Oriental in style and often carried a bluish-tinted glaze (Coysh 1970:7). By the 1830s, sharp lithographic prints in light colors such as pink, brown and lavender were in use (Gilmore 1986:79). Pastoral scenes in the blurred, flown blue style became popular after the 1840 s.

Transfer printed sherds in this collection span the range of colors and styles; an abundance of patterns are represented. Roughly $70 \%$ are printed underglaze blue, a color which was easy to fire and inexpensive to produce (Godden 1963:11). Several of these patterns have appeared in sherds from other early Texas sites. A number of patterns may be attributable to the Davenport potteries of Staffordshire, which were established in $\mathbf{1 7 9 4}$ (Lockett 1972:9).

Eight sherds are printed in black, with three patterns possibly represented. Six sherds, with a floral border incorporating swags, lacelike designs, masted ships and palm trees, are tentatively identified as the "Canova" pattern of T. Mayer, 


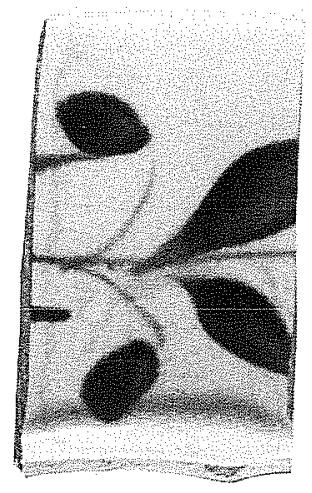

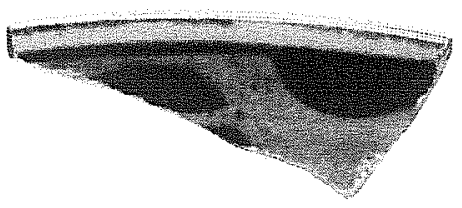

b

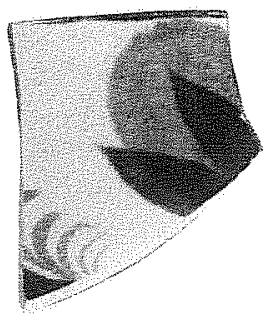

$\mathrm{C}$

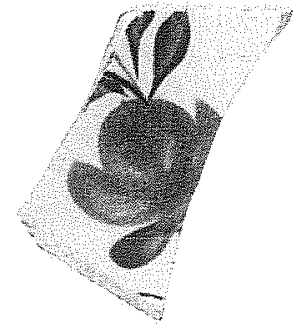

d

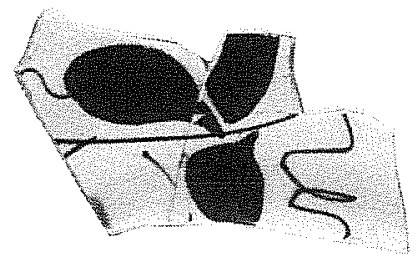

e
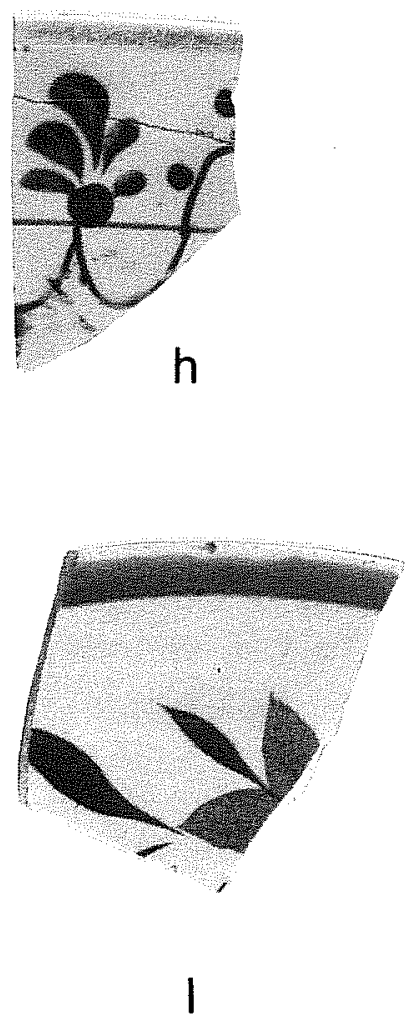

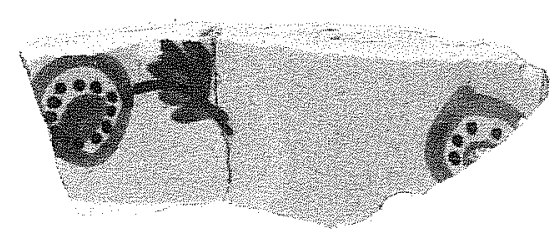

f
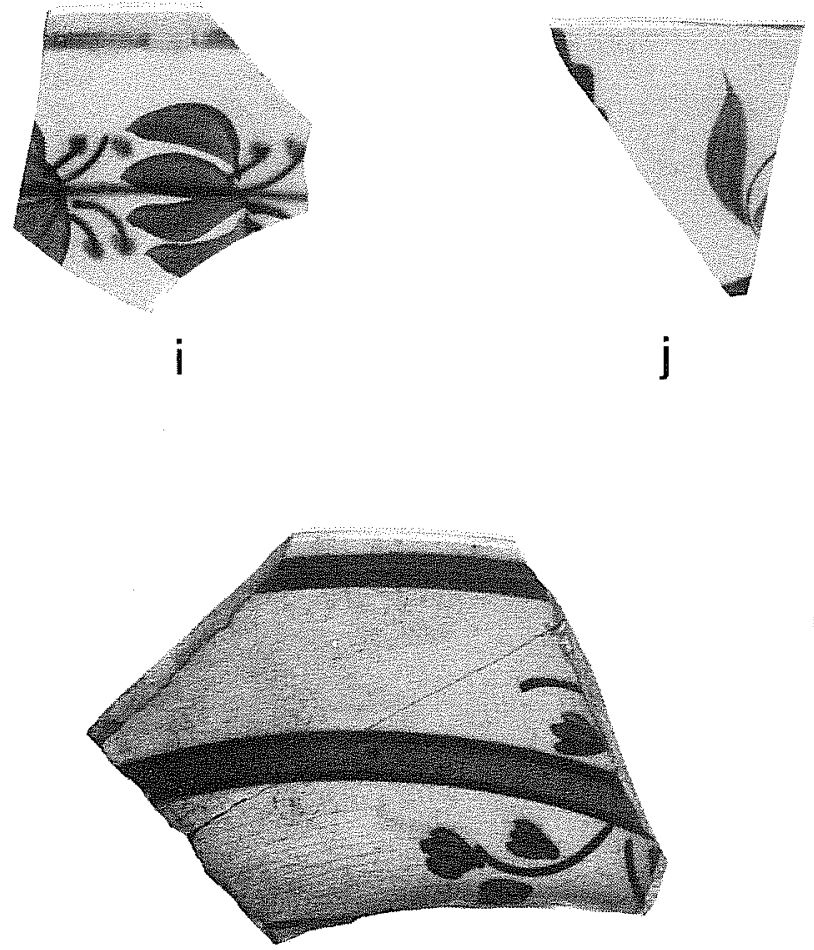

$\mathrm{m}$

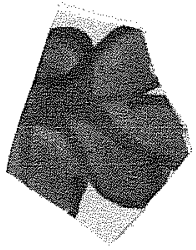

g

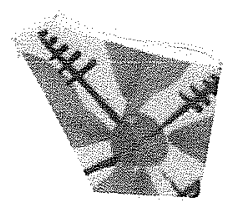

k

Figure 14. Hand-Painted Whitewares. a, blue and white; b, blue and white; $c$, blue and white with pale gold fronds; d, pink, green, and gold; e, green, black, and blue; f, green, yellow, and black; g, yellow and black; $h$, blue, yellow, and olive green; i, blue and yellow; j, blue, green, and brown; k, yellow and brown; 1 , pink, green, and blue; $\mathbf{m}$, blue and brown; $n$, yellow and brown. Shown actual size. 


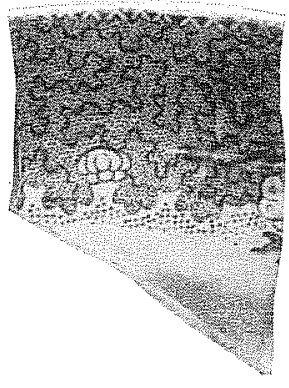

a

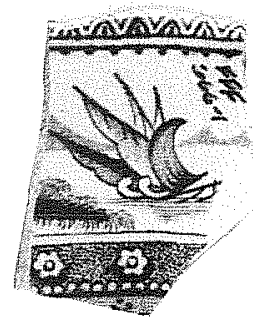

e

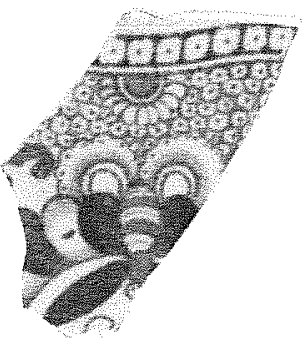

i

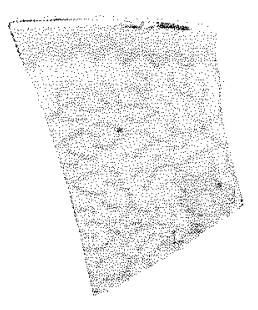

b

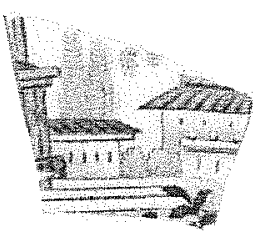

f
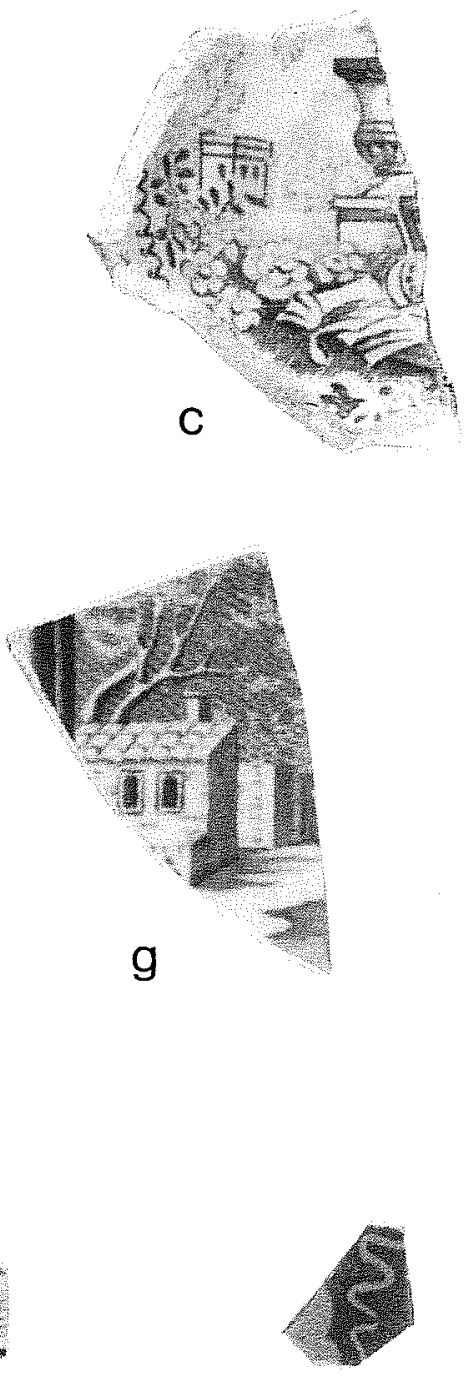

k

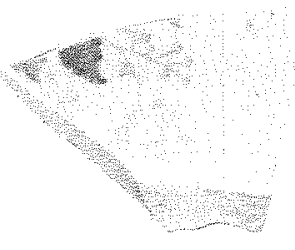

d
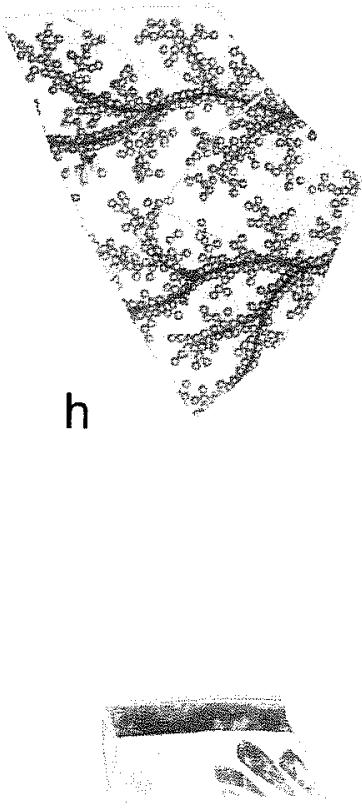

I

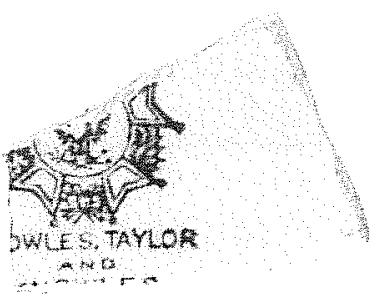

m

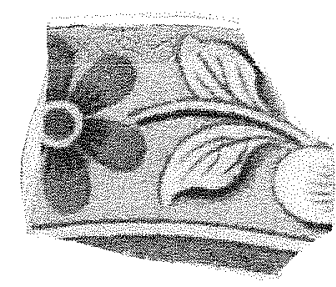

j
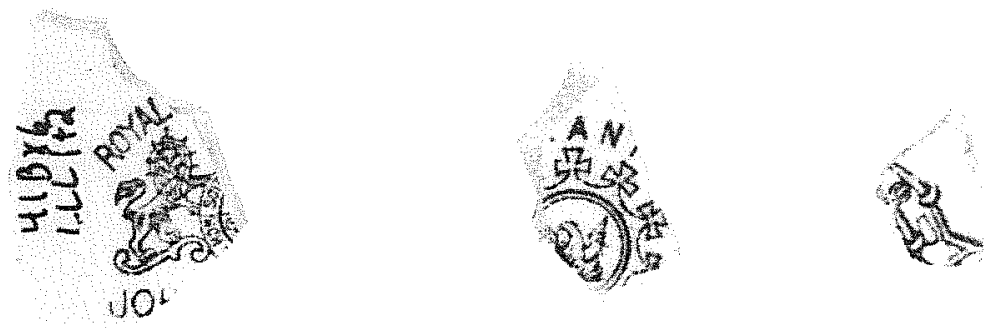

0

P

Figure 15. Transfer-Printed Wares and Maker's Marks. a, red transfer; b, pale blue transfer; c, blue transfer; d, blue transfer; e, black transfer, "Canova" pattern; f, green transfer, "Canova" pattern; g, blue transfer; $h$, red transfer, Davenport factory, "Coral" pattern; $i$, blue transfer; $j$, blue transfer; $\mathbf{k}$, pink luster decoration on whiteware; 1, pink luster decoration on redware; m, maker's mark, "Knowles, Taylor and Knowles," 1870-1890; n, maker's mark, "Johnson Brothers," 1883-1913; o, maker's mark, "Goodwin Pottery Company," 1885-1898; p, maker's mark, "Goodwin Pottery Company," 1898-1903. Shown actual size. 
Longport, England, 1836-1838 (Godden 1964:423). Three black and white sherds contain a scalloped lip. Forms represented include cup, saucer, and plate. This design was also represented in the collection from the La Villita excavations (Brown and McConnell 1987:1), and from Mission San Juan Capistrano (CAR collections).

The "Canova" pattern is carried also on one sherd printed in brown, two in green and one in lavender. A portion of the lion and urn maker's mark is printed on the underside of the lavender sherd.

Six small light blue on white sherds may correspond to a pattern recovered at the La Villita Earthworks, and identified as Jackson's Warranted "Peacock" (Brown and McConnell 1987). This pattern contains a large urn within a castle landscape, and is encircled by a distinctive interior border consisting of a finely scribbled line.

Job and John Jackson had a factory in Burslem from 1831 to 1835 (Godden 1964:349).

A red-on-white sprigged or branchlike pattern appears on a partially reconstructed cup attributable to the Davenport pottery. Sherds possibly representing saucers, a plate, and a handle fragment are printed in red. Sherds with this pattern printed in black from the La Villita excavations are stamped "DAVENPORT."

Virtually the same design made by W.T. Copeland from ca. 1832 to post-1847 is marked "Coral" (Sussman 1979:102).

Twenty or more patterns may be represented among the transfer sherds. Figure 15 shows the range of rim and body patterns, including cottage scenes. Oriental-style florals, and intricately varied geometric and floral borders. The flown blue style is not represented in the lunette trench sherds, but one sherd of this style came from a unit near the center of the 1989 excavations.

\section{Maker's Marks (Fig. 15,j-m)}

Trademarks and maker's marks frequently enable attribution to a particular pottery as well as time frame for the date of production of a vessel. A number of ironstone sherds carry a portion of a maker's mark. Two ironstone sherds bear portions of the mark of Knowles, Taylor and Knowles, of East Liverpool, Ohio. The addition of the Taylor name and an eagle to the trademark help place these sherds in the 1870 s or 1880 s (Ramsay 1976:216). These sherds came from the first level in the lunette trench. Another ironstone sherd, also from the first level in the trench, bears a portion of a crest and what appears to be the name of Johnson
Brothers of Hanley, England, for which the dating would be 1883-1913 (Godden 1964:355).

Two ironstone sherds have portions of two different marks of the Goodwin Pottery Company of East Liverpool (Ramsay 1976:216). One mark was in use from 1885 to 1898 , the other from 1898 to 1903. Both of these sherds came from late 19th century contexts in the 1989 excavations.

A portion of the British coat of arms is printed on another ironstone sherd. Variations of this mark were used by many British and American potteries in the 19th and 20th centuries.

\section{Spongeware/Spatterware ( 3 sherds)}

Spongewares/spatterwares are small, and have been sponge printed or spattered in blue (one sherd) or brown (two sherds) on a white background. The glaze on sherd exteriors has a bluish cast. Spongeware and spatterware decorations were applied over the entire vessel, or were reserved for rim bands which encircled a central, hand-painted floral or animal design (Robacher and Robacher n.d.).

Spongeware occurs in Texas sites dating from 1830 to 1870 (Hays and Jelks 1966:23; Greer 1967:30-32; Fox 1986:177). Sherd counts generally tend to be either very small, as in this collection and the La Villita collection (Fox 1986:108,Table 3), or relatively large as at Mission San Juan Capistrano (CAR collections), a trend which may prove to be temporally significant.

\section{Lusterware (19 sherds; Fig. 15,k,1)}

Luster ware was chiefly a peasant art, originating at the end of the 18th century in the Staffordshire area. The characteristic iridescent, metallike sheen was achieved by applying a metallic film to the earthenware or porcelain body (Bedford 1965:5-8). Luster decoration was added in a variety of techniques: over the entire vessel to achieve a gold or silver surface, a poor man's silverware (Fox 1988); hand painted or stencilled in bands, floral or geometric motifs; transfer printed; and resist-decorated.

In this collection, 13 luster decorated sherds have a gray buff paste. Of these, 11 are painted with fanciful pink luster, daisy-like flowers, and leaves encircling the rim, under a pink luster lip band. Sherds of this style are thin, and may have been from a saucer or bowl. Two other sherds are thicker with a simple pink luster band under the lip. The glaze is bluish. The vessel represented may be a mug or vase. 
Six small, thin sherds have a terra cotta paste; of these, five are painted in shades of iridescent blue purple with squiggled blue designs. The sixth sherd is painted in a solid gold copper color. The forms are not discernable.

\section{Miscellaneous (10 sherds)}

Five sherds are yelloware, which usually took the form of kitchen utility vessels. The glaze is clear-to-brownish, yellow (10YR8/6) to pale yellow $(2.5 Y R 8 / 4)$ over a cream yellow paste, white (10YR8/2) to very pale brown (10YR8/3). One sherd is cream colored on the exterior and yellow on the interior. This type may correspond to yelloware recovered at La Villita (Fox 1986:122). Another has a mottled brown and yellow glaze similar to Rockingham but probably a 19th-century American equivalent. One small fragment is colored in lime green on one side, rosy pink on the other. Two sherds are a deep lemon yellow with a glossy glaze over a white paste. This also may correspond to types found previously at the Alamo (Fox, Bass and Hester 1976:55).

\section{Porcelain and Semiporcelain (56 sherds)}

The term porcelain usually refers to a thin, vitrified, highly fired, translucent ceramic which produces a clear ring when tapped against a hard surface (Godden 1963:31; Rice 1987:6). Although Josiah Spode introduced a rival to the earlier Oriental form in 1790, many English potters strove to perfect a less fragile cross between porcelain and pottery which became "stone china," "semiporcelain", and "ironstone" (Godden 1963:13).

Porcelain and semiporcelain ceramics in this collection are chiefly undecorated. Most undecorated sherds are thin, hard and of a fused white paste. Plates, cups and saucers are the forms represented.

Of the four decorated sherds, one has an orange colored, oriental design in thin brush strokes. One has a stylized gray blue bird design in the bottom of a cup. Two others, decorated in gold luster overglaze, may be part of a narrow, cylindrical cup or small mug.

A heavier semiporcelain sherd - possibly from a mug - contains the faded trace of a blue green overglaze band under the rim.
Stoneware (68 sherds)

Stoneware is a dense, hard ceramic of moderately coarse clay which fuses and melts together at high temperatures (Greer 1981:15). Color of clay varies according to the amount of iron present; generally the paste is white, tan or gray. Although vitrified stoneware is impervious and does not require a glaze to seal the body, early American-made utilitarian wares commonly were finished in salt, alkaline, Bristol or Albany glazes or slips, producing surface shadings of green, red brown, brown, gold or gray white.

Types and combinations of glazes and slips provide information as to dating and manufacturers. A tentative chronological pattern for Texas stoneware is offered by Gilmore (1986:81). Identification of slips and glazes on some sherds is skewed by incomplete firing and immature color development. It is likely, however, that most of the stoneware in this collection is late or intrusive, probably produced after 1860 in Texas kilns such as those at Atascosa and Elmendorf. Ten sherds are from beverage bottles with lead or Bristol glazes.

Vessels were wheel thrown; distinct rilling marks are visible on most sherds. Common stoneware forms are jugs, bottles or jars, used predominantly for the transport and storage of liquids.

Three sherds bear variations of Albany slip interiors in combination with salt glaze. Exteriors are light gray (10YR7/1-7/2) with a glossy, pitted orange peel texture. The interior on one is mottled brown, with a low sheen, resembling tortoise shell (dark yellowish brown [10YR3/4]). This may be an Albany slip glaze. A second sherd is a flat, very dark, grayish brown (10YR3/2). The paste of both is light brownish gray (10YR6/2). The third salt glazed sherd is a neck rim, which apparently was immaturely fired. Neither the slip nor the glaze was formed properly, resulting in a rough, flat gray exterior and a slightly iridescent red interior. The core color is buff, striated with dark gray.

Four sherds have a dull, yellowish brown exterior (very pale brown [10YR7/4] to yellowish red [5YR5/6]) which may be an immature salt glaze. The paste is gray with a dark core. Two of these sherds are basal pieces of what may have been a narrow, cylindrical jug approximately $60 \mathrm{~mm}$ in diameter at the base.

Eight sherds have a red Albany slip, weak red (10R4/4) to dusky red (10R3/4). The paste color is very pale brown (10YR8/4). 
Five sherds are Bristol glazed over a very hard, fine white paste (near white [10Y8/2]) with small pepperpike inclusions. Glaze on four of the sherds is thick and shiny, creating a glossy white surface. The other sherd, in a duller glaze, is probably the base of a small bottle $80-90 \mathrm{~mm}$ in diameter at the base. Two or three different vessels - possibly Scottish-made beverage bottles - may be represented.

Seven sherds are markedly different in coloring. The paste is fine grained, weak red to red (10R5/4-5/6). Exterior surfaces are slipped and glazed a glossy reddish brown (three sherds) and brown (two sherds); interiors are creamy white; the walls are uniformly thin $(3 \mathrm{~mm})$. A rim sherd from a small bowl approximately $60-80 \mathrm{~mm}$ in diameter is encircled with three creamy white bands under the rim. Sherds of this category may correspond to a "hard paste, unidentified glassware" previously recovered at the Alamo (Greer 1967:36).

Two stoneware sherds appear to be salt glazed, with unidentified interior glazes, one is shades of yellow green, the other in red brown. The paste on both is reddish yellow (5YR7/4).

A basal sherd of a small bottle or ointment jar approximately $30-40 \mathrm{~mm}$ at the base has a whitish (near 10YR8/2) paste covered with a milky yellow glaze.

\section{Observations on Ceramics}

Nearly all the ceramic sherds were very small, particularly those from the 18th-century occupations of the area, perhaps reflecting the locations of the trash deposit along and possibly drifting into the path of the roadway into the mission. Some 2800 sherds were recovered during the two seasons (Table 1). Except for a minimal number of late-19th-century stoneware and ironstone sherds in the upper levels that represent later deposits over the top of the lunette trench fill, the sample can be confidently dated between the founding of Mission Valero on this site in 1724 and 1836 when the trench was filled. Judging from experience gained in excavation of other Spanish colonial sites in the San Antonio River valley, it would appear that the soft paste earthenwares are representative of the 18th century and the first decade or two of the 19th century. At some point about 1810 to 1820 , there seems to have been an abrupt change in source of supply from central Mexico to England via New Orleans. Logically, this can be blamed on the revolutionary upheavals in Mexico and Texas at that time. Further discussion of this subject can be found in the Summary and Conclusions of this report.

Of particular significance is the quantity and variety of types of European whiteware recovered. Approximately $42 \%$ of the total ceramic assemblage is of likely English origin (Table 2). This figure seems particularly large considering that only a few Anglo families lived in the village of San Antonio in 1836 , and none of them lived in this vicinity.

The large variety of English whiteware patterns suggests that many different sets of earthenware were in use in early-19th-century San Antonio. However, research at other early sites indicates that possession of entire sets was rare, and mixing of several patterns was common (Black 1987:249-257).

It is tempting to suggest that the recovery of certain identical or similar hand-painted and transfer-printed sherds from a variety of mission and early Texas sites indicates a patterned style preference for this period. However, it is possible that large quantities of whiteware out of favor in England were "dumped"on Texas and American markets, or were developed specifically to appeal to what the English potters perceived to be the early settlers' tastes, the choices therefore being made in England rather than in Texas.

Further research, both in historical accounts and in more stratified archaeological contexts, may provide further insights into the dating and origin of the many ceramic types represented in the lunette trench.

\section{Glass Containers}

A total of 1491 small fragments of glass was recovered in the 1988 and 1989 excavations. These are divided by color with the percentage of each in Table 3. It is interesting to note the differences in color percentages of the total glass recovered between the military trench fill (1988 and 1989 trench) and the area to the north in the 1989 excavations. The much higher percentages of clear and brown glass and the total absence of "black" glass confirm the later date of the deposits encountered to the north of the trench (see Kendrick 1967:20-22; Fox 1990: Table 2).

Dating of glass containers is generally accomplished by observing the techniques used in their manufacture (Lorrain 1968). Relatively few vessel fragments large enough for dating by manufacturing process were recovered during the entire two seasons. These datable ones are described in the following discussion.

"Black" glass wine bottles are represented by four heavy hand-blown basal fragments 
Soft Paste Earthenwares

Unglazed

Goliad Ware

Wheel-Thrown, Red-on Pink Ware

$\begin{array}{rr}279 & 64 \\ 88 & 35 \\ 19 & 0 \\ 32 & 1 \\ 2 & 0 \\ & \\ 197 & 23 \\ 9 & 0 \\ 356 & 6 \\ 36 & 0 \\ 7 & 0 \\ 22 & 0\end{array}$

Tin Glazed

Red Burnished Ware

Tonalá Burnished

Lead Glazed

Orange Paste, Incised

Sandy Paste Utility Ware

Olive Jar

Polychrome Decorated - Galera

Red Brown Ware

Tonalá Polychrome

Miscellaneous Lead-Glazed Ware

Mojolica

Puebla Polychrome

San Elizario

Unclassified Blue-on-White

Huejotzingo

Guanajuato

Unclassified Polychrome

Faience

Undecorated

Hard Paste Earthenwares

Undecorated Whiteware

Edgeware

Slipware

Hand Painted

Transfer Printed

Spongeware

Lusterware

Porcelain

Miscellaneous

\begin{tabular}{rr}
10 & 2 \\
13 & 0 \\
49 & 3 \\
16 & 1 \\
67 & 6 \\
33 & 2 \\
155 & 5 \\
5 & 0 \\
490 & 54 \\
66 & 1 \\
120 & 5 \\
180 & 6 \\
173 & 6 \\
3 & 0 \\
19 & 0 \\
7 & 3 \\
36 & 20 \\
31 & 37 \\
\hline 2520 & 280 \\
\hline
\end{tabular}

\begin{tabular}{||l|c|c||}
\hline \multicolumn{1}{|c||}{ TABLE 2. CERAMIC COMPARISONS ACCORDING TO ORIGIN } \\
\hline \multicolumn{1}{|c|}{ Ceramic Type } & $\begin{array}{c}\text { Total } \\
\text { Number }\end{array}$ & Percentage \\
\hline Refined Earthenwares (European Origin) & 1130 & 42 \\
\hline $\begin{array}{l}\text { Unglazed and Lead-Glazed Earthenwares and Majolicas } \\
\text { (Mexican import) }\end{array}$ & 1077 & 40 \\
\hline $\begin{array}{l}\text { Mission Indian (Goliad) and Red-on-Pink ware } \\
\text { (probably locally made) }\end{array}$ & 466 & 18 \\
\hline (Stoneware not included) & & \\
\hline
\end{tabular}




\begin{tabular}{|c|c|c|c|c|c|c|}
\hline \multicolumn{7}{|c|}{ TABLE 3. DISTRIBUTION OF GLASS } \\
\hline & \multicolumn{2}{|c|}{$\begin{array}{c}1988 \\
\text { Total Area }\end{array}$} & \multicolumn{2}{|c|}{$\begin{array}{c}1989 \\
\text { E-W Trench }\end{array}$} & \multicolumn{2}{|c|}{$\begin{array}{c}1989 \\
\text { Rest of Area }\end{array}$} \\
\hline & Total & Percentage & Total & Percentage & Total & Percentage \\
\hline Clear & 411 & 38 & 13 & 32 & 243 & 66 \\
\hline Black & 38 & 4 & 1 & 2 & - & - \\
\hline Green & 331 & 30 & 12 & 29 & 74 & 20 \\
\hline Brown & 91 & 8 & 3 & 7 & 30 & 8 \\
\hline Aqua & 162 & 15 & 5 & 12 & 7 & 2 \\
\hline Blue & 22 & 2 & 5 & 12 & 6 & 2 \\
\hline White & 18 & 2 & 1 & 3 & 3 & 1 \\
\hline Yellow & 6 & 0.5 & - & - & 1 & 0.5 \\
\hline Frosted & 6 & 0.5 & 1 & 3 & 1 & 1 \\
\hline Totals & 1085 & & 41 & & 3657 & \\
\hline
\end{tabular}

(Fig. 16,a,b). They survived, probably because of the thickness of the glass. Three of these bear ragged marks of a glass-tipped pontil rod, dating them before 1840 (Kendrick 1967:20). These all came from 20 to $100 \mathrm{~cm}$ deep in the 1988 trench and fall within the expected time range of the trench fill. An additional basal fragment (Fig. 16,c) shows mold marks around the outside of the base and up the side, characteristics of a mold-blown bottle. This artifact was recovered from the north end of the 1989 excavation, and conforms (Lorrain 1968:40) to the post-1840 date of the ceramics from that area.

Two dark olive green bottle necks (Fig. 16,d,e) have laid-on rings near the lip, and the lips are sheared, which would suggest a pre-1840 date of manufacture (Kendrick 1966:48; 1967:20). One came from about $60 \mathrm{~cm}$ deep in the 1988 trench, the other from the surface of the central section of the 1989 excavations. The former with a champagne finish is clearly identifiable as an early style, the latter could have been made well into the 19 th century, since wine bottles tend to be conservative in manufacturing technique, particularly those of European manufacture.

A small, delicate, clear glass bottle, possibly for medicine is represented by numerous fragments that were recovered in bottom of the 1988 trench fill. The bottle may have been nearly whole when it was deposited in the trench, as a large percentage of it was recovered. A pontil mark on the base has been smoothed off, perhaps to allow the bottle to sit securely flat on a table or shelf. The delicacy of the glass suggests a medicine bottle. The manufacturing date would have been pre-1840 and perhaps post- 1800 . Its diameter ( 2 inches) is larger than most 18th-century medicine bottles found in Spanish contexts in San Antonio.

Two pale aqua bottle necks with oil finish (Fike 1987:Fig. 2, 2.11) were recovered. One of these is from a hand-blown bottle (Fig. 16,f) with applied rim found in the 1988 trench excavation on the top of the lunette. The glass is uneven in thickness, and the neck shows evidence of having been formed by twisting upward. It probably contained some type of cosmetic or cooking oil and dates to the 18th century or early 19 th century. The other bottle neck represents a blown-in-mold bottle (Fig. 16,g) with raised lettering of the type popular in the $1880 \mathrm{~s}$ (Munsey 1970:174). It came from a disturbed area at the north end of the 1988 excavations at about 60 $\mathrm{cm}$.

An aqua canning jar neck (Fig. 16,h) fragment has the screw top, shoulder shape, and wide mouth typical of a canning jar made in the 1880 s to 1890 s 


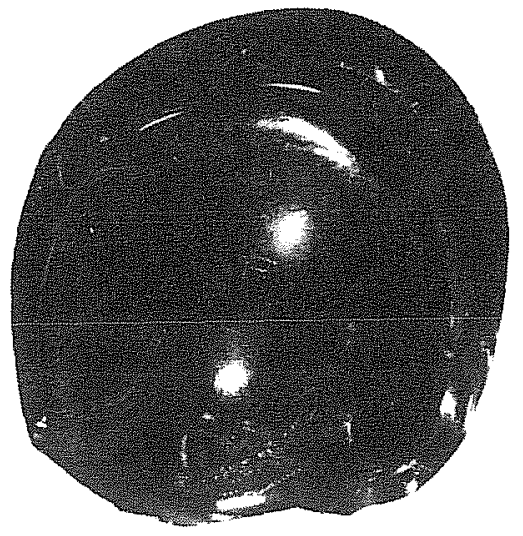

a
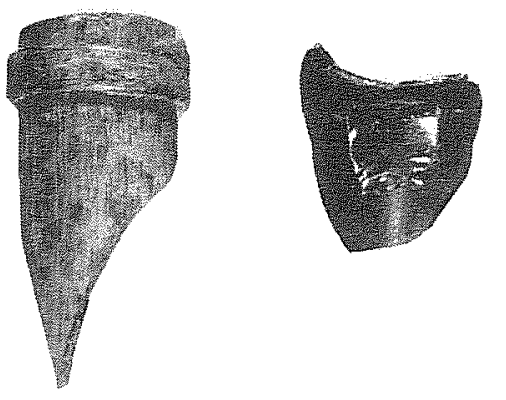

d

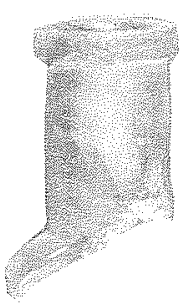

i

$\mathrm{m}$

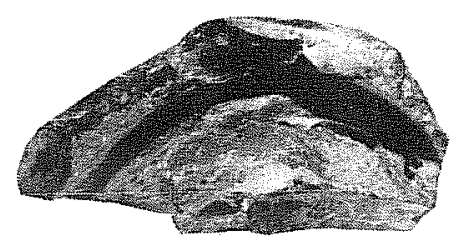

b

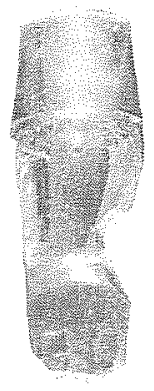

g

$f$

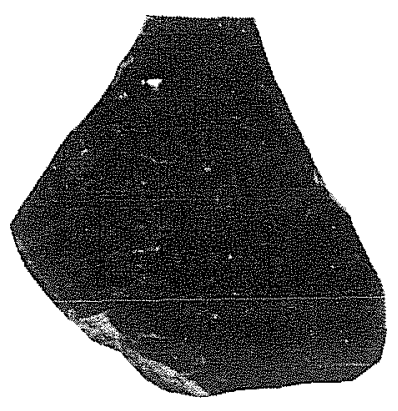

C

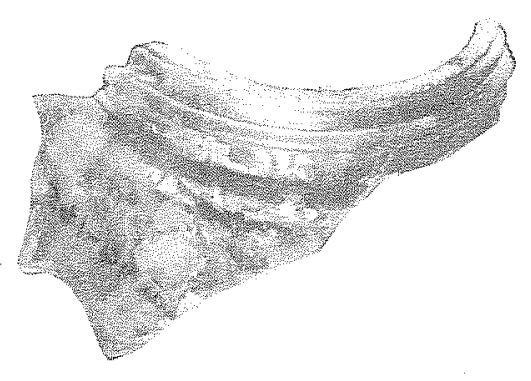

$\mathrm{h}$

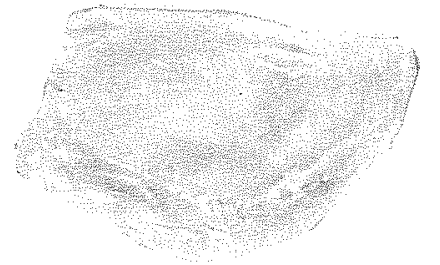

k

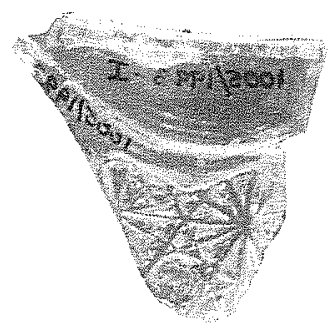

O
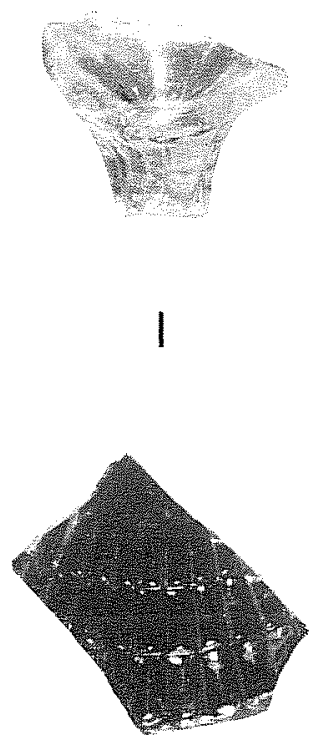

$\mathrm{p}$

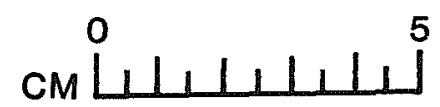

Figure 16. Glass Containers. a,b, black glass wine bottle base; c, black glass bottle base with mold marks; d,e, olive green bottle neck, champagne finish; $\mathrm{f}$, aqua bottle neck, hand blown with applied rim; $\mathrm{g}$, aqua bottle neck, blown-in-mold; h, aqua canning jar, screw top; i, aqua prescription finish neck; j, amber prescription finish neck; k, fluted pressed glass tumbler base; 1 , stem of goblet; $m$, milk glass cup or vase fragment; $n$, blue glass container lid sherd; o, blue glass container body sherd; p, amber glass container lid sherd. 
(Brantley 1975). Although such jars were made in the late 19th century, home canning did not become popular in Texas until about 1910 (Moir 1982:151). Canning jars are usually not found on San Antonio sites before that time.

Prescription finish bottles are represented by two necks from medicine bottles (Fig. 16,i,j). The neck fragments indicate use of a two-piece mold dating them to the post-1850s period (Munsey 1970:32). An aqua bottle neck with no visible mold marks came from the top level of fill over the east-west trench in the 1989 excavations. An amber bottle neck, also with no mold marks, is from a small, square bottle. This was recovered from the first level of fill over the lunette trench in the 1988 excavations.

Drinking glasses are represented by a portion of the heavy base of a clear, fluted, pressed glass tumbler (Fig. 16,k) that was recovered from the second level in the lunette trench in 1988. Similar tumblers have been found in early-19th-century deposits elsewhere in San Antonio (see Labadie 1986:157, Fig. 46,a). The lower half of the stem of a clear glass goblet (Fig. 16,1) came from the $30 \mathrm{~cm}$ level of a unit at the north end of the 1989 excavations. The approximate date of manufacture is mid-19th century.

One fragment of a pressed milk glass cup or vase bears a raised design of grapes and leaves. Found in the second level of the lunette trench in 1988, its dating is uncertain, but it is probably late 19th century.

Two fragments of a clear glass vessel with a fernlike etched design were found in the top levels of fill in 1988. The thickness of the glass and the sophistication of its manufacturing technique suggest a turn-of-the-century date.

Pressed glass containers are represented by four fragments of colored, pressed glass which appear to represent covered jars. Two of pale blue glass are from a patterned jar with a wide mouth, which came from the first level of fill in the center section of the 1989 excavations. A patterned fragment of the same colored glass that appears to fit the jar was found in the fill over the trench in 1988. An amber-colored lid fragment of similar pattern came from Level 3 at the north end of the 1989 excavations and appears to be contemporary with the milk glass fragment described previously. Objects identical to these lidded jars are still sold today.

\section{IRON SCRAP}

Unidentifiable small fragments of rusted iron varying from the thickness of tin (ca. $1 \mathrm{~mm}$ ) to that of cast iron cooking vessels (ca. $4 \mathrm{~mm}$ ) have been arbitrarily included under the Kitchen/Dining Artifacts category. In 1988, the excavations yielded 1476 fragments of this material. In 1989, 935 were recovered.

\section{TABLEWARE}

A fragment of a kitchen knife has a tang in line with the back of the blade, similar to those described by Simmons and Turley (1980:130) as being found on 18th-century Hispanic occupation sites. An iron spoon handle was also found. Both came from $40 \mathrm{~cm}$ deep in the lunette trench.

\section{CLOTHING}

The only objects recovered that could with any assurance be related to clothing were buttons and buckles. The buttons from the excavations have been divided into two groups. All metal buttons have been included in the military category, since by far the majority of them appear to belong to that group. Buttons of bone, shell, and ceramic have been grouped with the civilian component of the site.

Six bone buttons were recovered, all from the 1988 excavations at the lunette trench. Five of these have a single hole in the center (Fig. 17,a). Of these, four are $12 \mathrm{~mm}$ in diameter, and one measures 17 $\mathrm{mm}$. South (1964:119) has found these buttons in a 1726 to 1776 context. The sixth button, which originally had five holes in a central depression (Fig. $17, \mathrm{~b})$, is $18 \mathrm{~mm}$ in diameter and corresponds to South's (1964:121) Type 19 found by him in 1800 to 1830 contexts. Both of these types are consistent with the 1836 cut-off date for the trench deposits.

Three shell buttons were recovered, all ca. $8 \mathrm{~mm}$ in diameter, with four holes drilled in central depressions of varying depth (Fig. 17,c). Two of these came from the 1988 trench fill, and one came from the second level at the north end of the 1989 excavations.

Three white ceramic buttons were recovered. Of these, two had four holes drilled in central depressions. One was $10 \mathrm{~mm}$ and the other (Fig. 17,d) $14 \mathrm{~mm}$ in diameter. The third button, 10 $\mathrm{mm}$ in diameter, had an indentation in the back receive a metal loop for fastening the button to a garment. Similar buttons made of shell were observed in a mid-19th-century burial at the Choke 


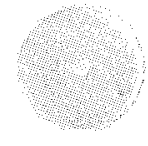

a

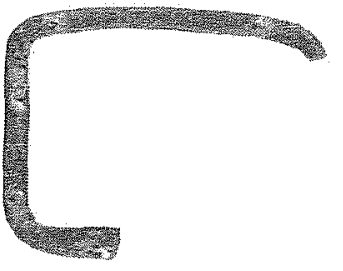

f

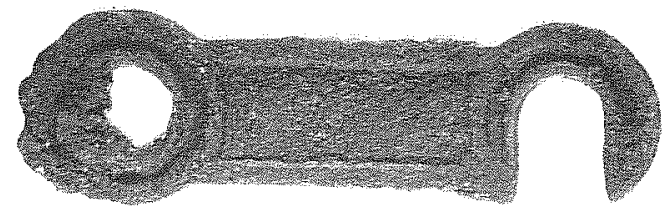

j

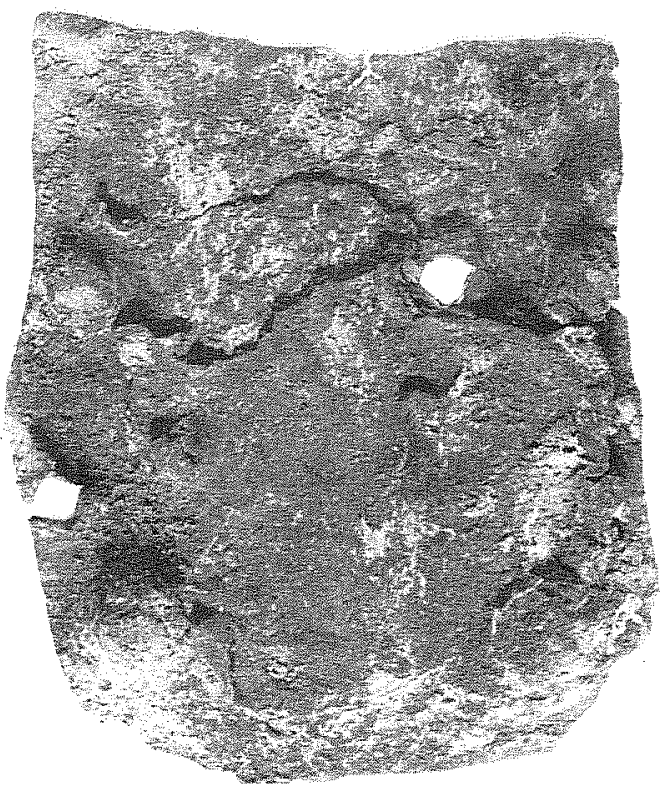

m
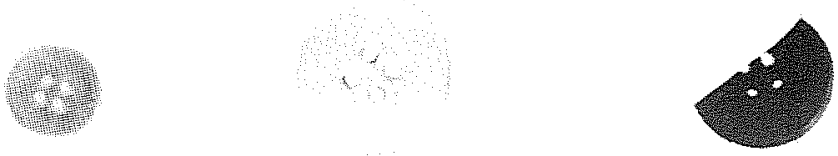

C

d

e

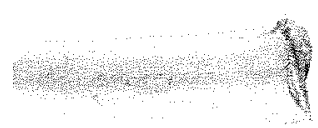

h

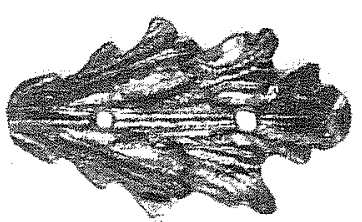

k
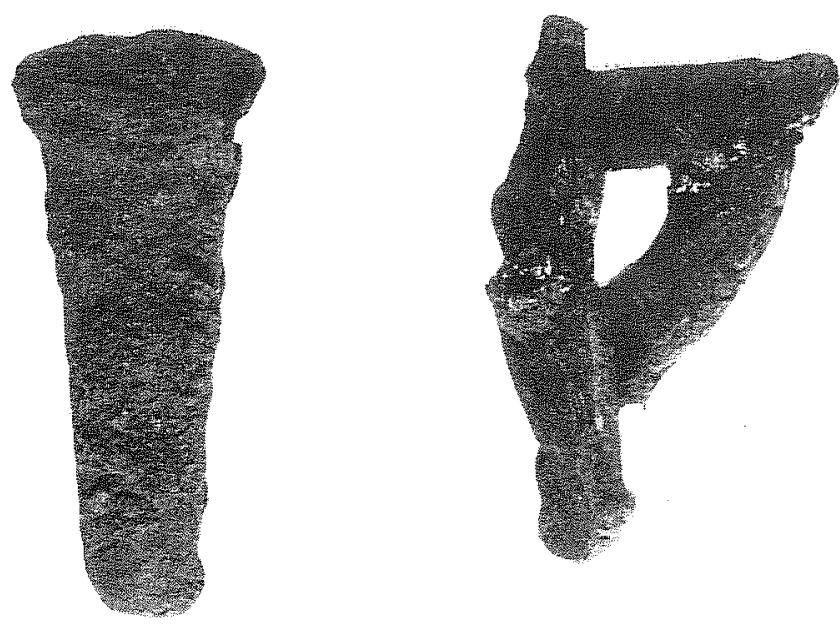

$n$

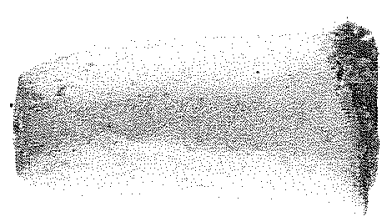

i

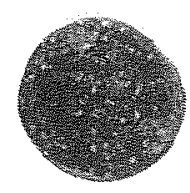

I

o

Figure 17. Miscellaneous Household and Personal Items. a, bone button with one hole; b, bone button with five holes; c, shell button; d, ceramic button; e, rubber button; f, buckle fragment; $g$, finger ring; h, white clay pipe, imported; i, locally made clay pipe; $\mathrm{j}$, cabinet door latch; $\mathrm{k}$, gold-plated decorative object; 1 , copper rivet; $\mathrm{m}$, copper patch for kitchen utensil; $n$, cast iron vessel leg; o, cast iron vessel handle attachment. Shown actual size. 
Canyon Reservoir in McMullen County (Fox 1984:43). The first-described button came from the $30 \mathrm{~cm}$ level at the north end of the 1989 excavations in company with decorated whiteware and ironstone sherds. The others came from 10 to $20 \mathrm{~cm}$ deep nearer the center of the same excavations. All three could reasonably be dated to the first half of the 19th century.

A portion of a dark brown four-hole button (Fig. 17,e) appears to be made of Indian rubber (gutta-percha). Charles Goodyear perfected the vulcanizing process that allowed the successful manufacture of buttons from this material in 1851 (Albert and Kent 1949:66-68). The same material was used to make combs, knife handles, and other objects in the last part of the 19th century. This button came from the $30 \mathrm{~cm}$ level in the lunette trench fill, which suggests some mixing with 19th-century materials occurred near the original plaza surface.

A single small, one-piece iron button, measuring approximately $1.6 \mathrm{~cm}$ in diameter was found at the north end of the 1989 excavations. This is the only other button recovered that appears to date to the late 19th century and, as such, fits well in its context within the site.

A partial buckle (Fig. 17,f) made of cuprous wire was found in the lunette trench. This was too fragile to have been intended for anything but clothing, perhaps as a belt buckle.

\section{PERSONAL ARTIFACTS}

Three glass beads were recovered during the excavations. A small blue bead from the third level in the lunette trench fill is of a type identified by $R$. K. Harris as follows:

\section{"No. 80. Small [under $0.5 \mathrm{~cm}$ ] Peacock Blue, translucent donut to barrel-shaped garter bead of simple construction."}

Identical beads have been excavated at the other San Antonio missions, as well as at Mission Rosario at Goliad (Gilmore 1973:69-70) and the Gilbert site, a Wichita Indian site in Rains County occupied ca. 1740 to 1770 (Jelks 1967:103-104).

A smaller, blue-green bead from the fill of the trench found in 1989 is identical to one identified at the Cogdell burial site. This burial is estimated to date to the mid-19th century. The description is as follows (Word and Fox 1975:17):
"Small aquamarine, translucent, donut-shaped embroidery bead of simple construction."

Half of a larger glass bead $(0.6 \mathrm{~cm}$ in diameter $)$ from the second level in the lunette trench can be described as a large, tan-colored, opaque, round necklace bead of simple construction. The tan color appears to be a thin layer of patina over clear glass. No information is available to date this bead, but it does not resemble trade beads recorded by Harris and Harris (1967) for Texas.

A partial ring of cuprous metal might possibly be identified as a finger ring (Fig. 17,g). It was found $40 \mathrm{~cm}$ deep in the fill of the section of fortification trench excavated in 1988.

Two fragments of mirror glass were recovered, both of them within 20 to $30 \mathrm{~cm}$ of the surface. One was in the lunette trench fill of the 1988 field school, one from the northern end of the excavation area in 1989. There is no way to date these objects, since small mirrors were used as trade items in the 18th century and the use of such mirrors has continued to the present day.

A stem fragment from a long-stemmed white clay smoking pipe (Fig. 17,h) of the variety popular in the 17th through 19th centuries came from the fill of the section of the lunette trench excavated in 1989. Such pipes were cheap and plentiful and "literally millions of them were made in both Europe and the United States" (Wilson 1966:33) during the 19th century alone. This particular fragment came from the end nearest the bowl, and bears the base of the spur.

A very different stem fragment is from a pale gray hand-shaped, short stemmed pipe (Fig. 17,i) made to be used with a separate stem. In color and texture, the clay from which this pipe was made resembles that of coastal Indian pottery. It was found in trench fill at the intersection of the two trenches during the 1988 excavations. A third fragment if from a pinkish tan, hand-formed pipe bowl with a small diameter (ca. $5 / 8$ inch). The clay from which it was made closely resembles that of Goliad ware, implying that it was a local product. It was recovered from the Stratum VII fill in the section of the east-west fortification trench excavated in 1989.

\section{HOUSEHOLD FURNISHINGS}

A small cast iron latch (Fig. 17,j) which may have been used on a chest or cabinet door was recovered from Level 1 at the north end of the lunette excavations in 1988. The design on the front side is 
similar to that on iron hardware listed in the 1897 Sears Roebuck Catalog (Israel 1968). It could either have been brought in as part of the park fill or have fallen off an object being used in or carried through the plaza at the turn of the century.

A gold-plated leaf-shaped object (Fig. 17,k) found in the second level at the north end of the 1989 excavations appears to have once been applied as a decoration. Two holes for nails or tacks pierce the centerline of the object. Found in the same level of this unit were a sherd of Goliad ware and one of thin undecorated majolica, 16 chert fragments, some bone fragments, and small pieces of rusted iron.

Two sherds from a small, tan-colored unglazed flower pot were recovered from the $20 \mathrm{~cm}$ level at the north end of the excavation area of 1989. Artifacts recovered from the same vicinity in this unit date primarily to the early 20 th century.

Five small copper or brass tacks from the lunette trench fill are of the type used to ornament wooden or leather objects such as furniture, chests, or trunks. The shanks are square in cross section, and the heads are slightly domed. Similar tacks are frequently found in Spanish colonial sites in Texas. A small-headed, cuprous nail $1.6 \mathrm{~cm}$ long also came from the lunette trench fill. Its use is not known, but it strongly resembles nails used in boot-making or in mounting decorative metal onto furniture.

\section{KITCHENWARE}

A copper patch (Fig. 17,m) that was used to mend a kitchen utensil still bears several rivets and a portion of the vessel to which it was applied. It was found in the fill of the lunette trench. Two copper rivets found in the contents of the lunette trench were probably used to attach handles or patches to copper utensils. One measures $1.8 \mathrm{~cm}$ in diameter, is $1.1 \mathrm{~cm}$ long, and appears charred as if it had been burned; the other (Fig. 17,1) is $2.8 \mathrm{~cm}$ in diameter and $1.7 \mathrm{~cm}$ long. Similar rivets were also used to hold together pieces of leather equipment, but the heads were smaller in diameter than that of the second piece described here (see Barn/Workshop Artifacts section).

Of two pieces of cast iron cooking vessel, one fragment (Fig. 17,n) is one of the three legs commonly found on these vessels. The other fragment (Fig. 17,0) is the "ear" to which a bale handle was attached. The shape and cross section of the ears can be used to date English cast iron cooking pots (Tyler 1974:151), such as are found in east coast colonial sites. On the whole, Tyler's criteria have been found to hold true for cast iron pots recovered in the San Antonio area as well. The round cross section of the ear on this piece would tend to date it to the early-to-mid-18th century. The overall shape of the ear in profile would put it in the late 18th century to early 19 th century. The profile of the pot wall to which this ear was attached indicates a nearly straight-sided vessel, in contrast to the usual bulbous shape of 18 th-century and early-19th-century cooking pots. This may indicate that the vessel was a straight-sided dutch oven, which would have had a deeply flanged lid onto which hot coals were heaped during cooking (Smith 1981:156).

\section{BONE}

An impressively large number of bone fragments was recovered during the two seasons of excavation (Table 4). The numbers are deceptive, however, because of the extremely fragmentary nature of the bones, particularly the ones included in the trench fill. This is probably due to the number of times these deposits had been trampled, moved around, and moved again over the years until they were buried in the trench. For this reason, plus the fact that the fill contained the discards of such a long and varied occupation, it was felt that no particular purpose would be served in doing detailed faunal analysis of these collections.

\section{ACTIVITY-RELATED ARTIFACTS}

Four clay marbles and a harmonica reed are described, along with problematical stone discs which may be gaming pieces, and slate fragments and pencils.

All of the marbles came from the lunette fill during the 1988 field school. Two white clay marbles $(1.3 \mathrm{~cm}$ and $1.5 \mathrm{~cm})$ are quite regularly spherical and were probably made elsewhere. A third (1.3 am) is lopsided, made of local clay, fired in an open fire, and probably made nearby. The fourth marble (actually half a marble) is larger (2.0 $\mathrm{cm}$ ) and uniformly spherical. It is evenly fired to a red orange color similar to that of the bricks made at the missions, and is probably also a local product.

Found in the first level in the east-west trench, a harmonica reed plate is made of cuprous metal (Fig. 18,a). It is cruder and heavier than reed plates found in late-19th-century sites and appears to have been handmade. The configuration of the slots in the plate suggests that the reeds were attached with screws or rivets along one edge of the plate.

The harmonica or mouth organ was invented by Sir Charles Wheatstone in 1829. Wheatstone's 


\begin{tabular}{|l|r|l|l||}
\hline \multicolumn{3}{|c||}{ TABLE 4. TOTAL NUMBER OF BONE FRAGMENTS RECOVERED } \\
\hline \multicolumn{2}{|c|}{1988} & \multicolumn{2}{c|}{1989} \\
\hline Lunette trench & 8928 & Trench fill & 1283 \\
\hline East-west trench & 1660 & Area to north & 1224 \\
\hline Total trench fill & 10,588 & & 2507 \\
\hline Periphery & 1243 & & \\
\hline Site total & 11,831 & & \\
\hline
\end{tabular}

instrument consisted of a metal box which held "a few free reeds," each supplied with wind separately from the mouth of the player (Encyclopaedia Britannica 1946:199). Free reeds are a metal tongues that are screwed or riveted over apertures in a metal frame. They are caused to vibrate by air pressure supplied by blowing. The pitch of each reed is determined by the length and thickness of the tongue, which is tuned by filing (Baines 1961:318). Four sandstone discs (Fig. 18,b,c), ranging in diameter from $1.5 \mathrm{~cm}$ to $6 \mathrm{~cm}$ were recovered from the fill of the lunette trench. Schuetz (1967:74-75) has identified similar artifacts from Mission San Juan Capistrano and Mission San José $(1970: 5,9)$ as gaming stones. Identical objects also were reported by Mounger (1959:246-247, Plate 38) from Mission Espiritu Santo at Goliad.

Discoidal objects made of stone and of reshaped ceramic sherds have been found throughout Texas on both prehistoric and historic sites. They are also found on prehistoric and historic sites in Florida (Deagan 1974:93), Arizona (DiPeso 1951:109; Toulouse 1949:22), and California (Moriarty and Broms 1971:16). The general consensus is that these objects were used in some sort of game. Evidence of the continuing creation and use of these objects into the Historic period at least as late as the early 20th century was found in excavations for the Laredo City Toll Plaza by CAR in 1980 (Folan, et al. 1986:31). Forty-eight sherds made into discoidals from this site dated from Spanish colonial to early-20th-century times.

Fragments of slate, probably from wood-framed slates used in the 19th century, were recovered from 19th-century proveniences in both seasons. A small slate fragment was recovered from the first level of excavation over the lunette trench in 1988. Another fragment was found $20 \mathrm{~cm}$ deep at the north end of the 1989 excavations, along with two slate pencil fragments (Fig. 18,d).
A thin copper disc with a portion of one side missing found in the lunette trench fill shows some evidence of a gilt finish, possibly a coin. There is no evidence of a shank attachment, and, there are no markings visible on either face.

\section{BARN/WORKSHOP ARTIFACT}

Two deer antler tines that were apparently used as tools were found in the fill of the lunette trench during the 1988 field school. A complete tine (11 $\mathrm{cm}$ long; Fig. 18,e) that was detached at the point where it sprung from the main body of the antler came from the $40 \mathrm{~cm}$ level of excavation. It was cleanly cut away with a sharp instrument (not a saw). The distal end of the tool shows a high polish around the entire circumference from the top to a point about $3.5 \mathrm{~cm}$ up the tine. Otherwise it is unaltered.

The other tine (Fig. 18,f), found at $100 \mathrm{~cm}$, has been broken at the larger end, and resharpened at the pointed or distal end. It is only $6.2 \mathrm{~cm}$ long. The facets created by the resharpening tool, probably a knife, are relatively clear; the tip shows minimal wear and no polish. Perhaps the tool broke in half soon after it was resharpened.

The purpose for which these tools were created is not known. Antler tines are not unusual in prehistoric Indian sites in central Texas. Prehistorians seem to classify these as flint-working tools. Tunnell (Tunnell and Newcomb 1969:132) found a tine at Mission San Lorenzo which had the distal end altered to make a flaking tool: "a long beveled facet has been ground at the end to produce a working edge shaped like the end of a screwdriver." Tunnell also observed scratches and grooves along the tine, which would seem to reinforce his conclusion that this was a flaking tool. A small, burned fragment of another tine was recovered at Mission Concepción (Scurlock and 


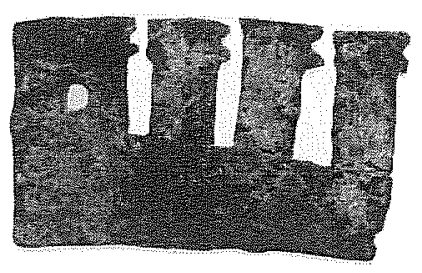

a

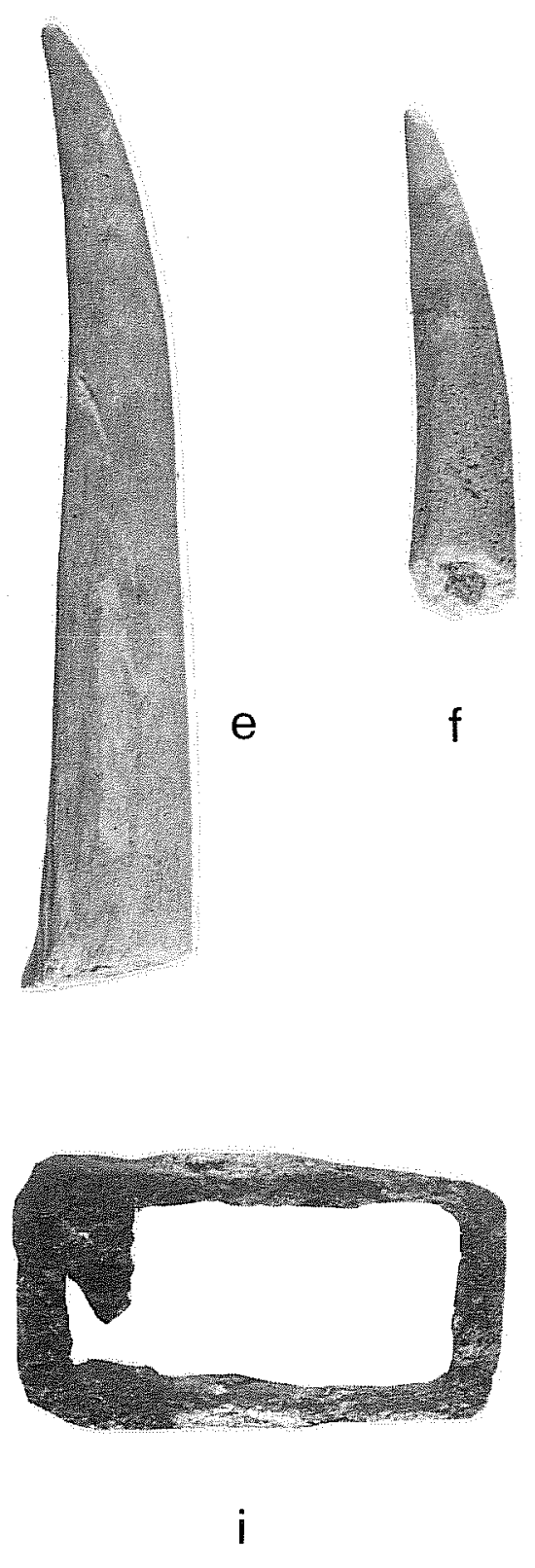

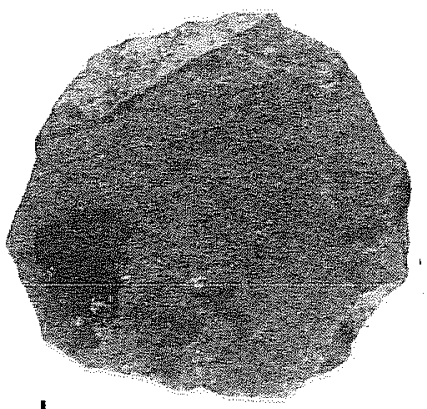

b
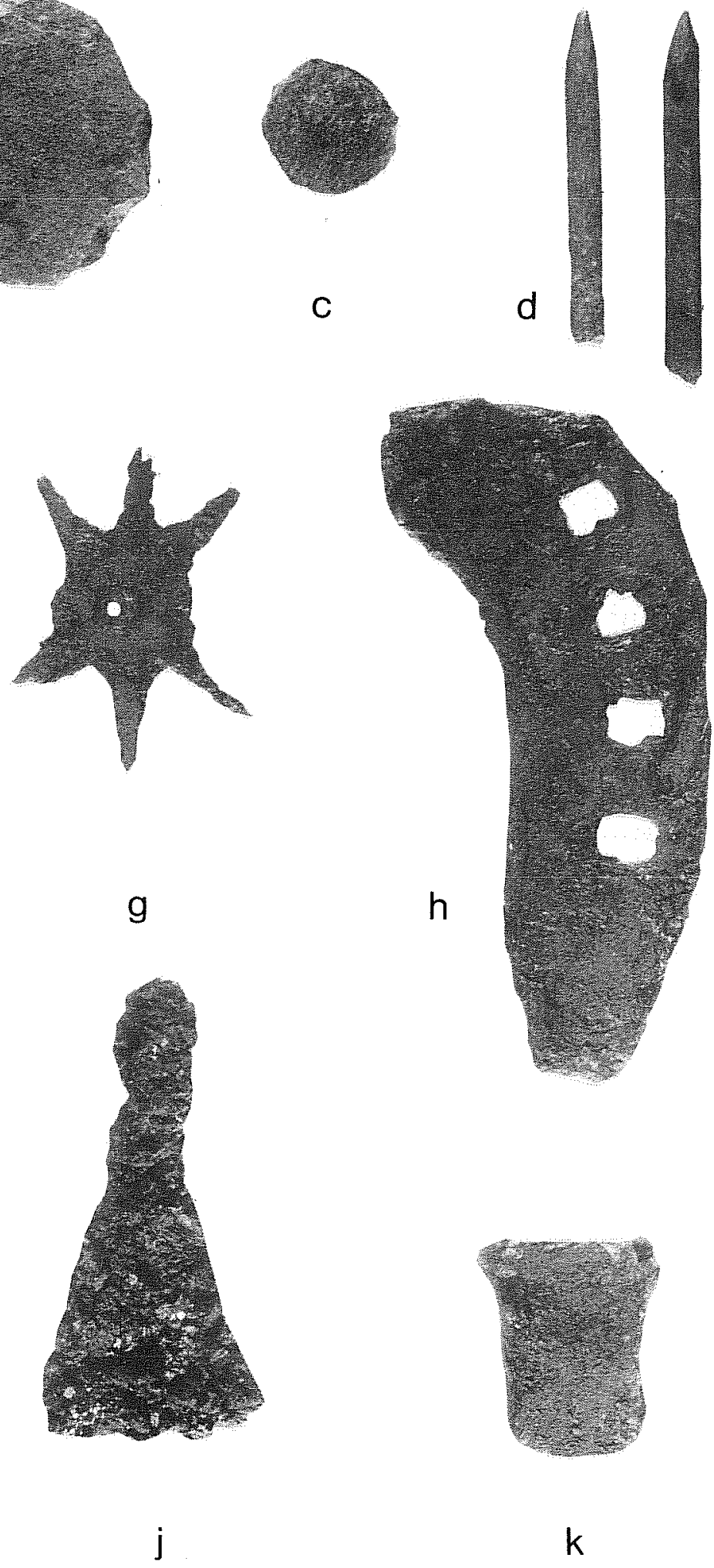

k

Figure 18. Activities and Barn/Workshop Items. a, harmonica reed plate; b,c, stone disc; d, slate pencils; e,f, deer antler tool; g, spur rowell; $h$, Spanish horseshoe; i, iron cut-off; j, buckle; $k$, jingle or coscojo. Shown actual size. 
Fox 1977:139), but no further description is available. Schuetz (1969:77, Plate 33,G) at Mission San Juan Capistrano recovered a longer tine tool $(14 \mathrm{~cm})$, crudely chopped off at the proximal end and bearing facets from sharpening, especially on the distal half. Polish extends up from the tip about $3.5 \mathrm{~cm}$. The wear pattern on this artifact and those from the field school excavations suggests that they were used for punching holes in something relatively soft but resistant such as leather. Reexamination of the San Juan specimen confirms that this is antler rather than bone as suggested in the publication. Probably other "bone" artifacts of a similar nature should be reexamined for identification as well as for wear patterns. The faceting resulting from sharpening tends to make the artifact resemble a worked bone tool, and it is only by examining the cross section at the proximal end that it can be safely identified as antler.

Numerous pieces of horse-related items were excavated during the two field schools. These consisted of spur rowels, horseshoes, fasteners for saddles and bridles, dangles and chain links. Most of these objects came from the fill of the lunette trench.

Two badly rusted spur rowels from the lunette trench fill are in the collection. One is $4 \mathrm{~cm}$ across and once had six spikes, the other is $4.4 \mathrm{~cm}$ across and had eight spikes (Fig. 18,g). These are comparatively small for Spanish rowels, but may have lost a bit in dimension during the scaling of rust. One from Mission San Juan is $6.5 \mathrm{~cm}$ across (collection at CAR), and two from Mission Espiritu Santo (Mounger 1959:Plate 52) are $8 \mathrm{~cm}$ and $9 \mathrm{~cm}$ across, respectively. All of these have six spikes. A similar rowel excavated at the La Villita Earthworks site in San Antonio (Labadie 1986:97, Fig.30,b) measures $5 \mathrm{~cm}$ across and has eight spikes.

One Spanish and two American horseshoe fragments were excavated. Spanish colonial shoes have a wide web and large square countersunk nail holes (Simmons and Turney 1980:61). The Spanish shoe (Fig. 18,h) came from near the top in the lunette trench. One American shoe was excavated from the fill above the east-west trench in 1988, the other from $20 \mathrm{~cm}$ at the north end of the 1989 excavations. A similar Spanish shoe came from the La Villita site (Labadie 1986:95, Fig.29). It is interesting to note that the shape and method of construction of these Spanish horseshoes are nearly identical to shoes excavated from 17 th and early 18th centuries English sites in Virginia (Noel Hume 1969:238, Fig.74, 1-4). Cut-offs (Fig. 18,i) made by a blacksmith or farrier working in the area in the
18 th or 19 th century were also recovered from the lunette trench fill.

A large, heavy cuprous metal rivet was probably used to fasten parts of a saddle or harness together. It was found in the backdirt at the south end of the lunette trench during the last day's excavation. A smaller copper rivet from the second level of the 1988 excavations was probably also a leather-fastening device.

A rectangular harness buckle (Fig. 18,j) came from the $60 \mathrm{~cm}$ level near the end of the lunette trench. It probably dates to the early 19 th century, as it more closely resembles later examples from late 19th-century sites than those used in the 18th century (Simmons and Turley 1980:14).

Five badly rusted s-shaped chain links typical of Spanish bridle and harness chains also came from the upper levels. This particular shape is diagnostic of Spanish horse equipment (Simmons and Turley 1980:101). Similar chain links have been recovered in previous excavations at the Alamo (Fox, Bass, and Hester 1976:64, Fig.25,c) and at Rancho de las Cabras near Floresville, as well as at Mission Rosario (Gilmore 1974:Plate2,7b,f) and the San Xavier Missions in Milam County (Gilmore 1969:108, Fig.10).

Three jingles or coscojos were recovered from 40 to $50 \mathrm{~cm}$ in the lunette trench in 1988 . Rows of these jingles were hung from a Spanish bridle's bottom bar or bridge, which was mounted to the shanks of the bit by pivots allowing it to swing freely below the horse's lower lip (Simmons and Turley 1980:103). All but one of the jingles recovered were too badly rusted to tell their exact original shape and size. The other (Fig. 18,k) is $6.5 \mathrm{~cm}$ long and triangular in outline. Jingles of similar size have been excavated at numerous Spanish sites, including the north courtyard in the Alamo (Schuetz n.d.:59, Fig. 15,D), Rancho de las Cabras (Ivey 1983:Fig. 4,b-d), Mission Rosario (Gilmore 1974:Plate 27,c-e, g), and the San Xavier Missions (Gilmore 1969:Fig.10).

\section{MILITARY ARTIFACTS (Samuel Nesmith)}

As might be expected, a large number of military-related items were recovered from the excavations, primarily from the area adjacent to the south entrance gate of the compound. These consisted of gun flints, lead balls and lead scrap from making them, howitzer shell fragments, and uniform parts such as buttons and insignia. Also included here are metal buttons that appear to be of the early-19th-century period around the time of the battle, but are not necessarily of military origin. 
The following flints were found at various levels within the fill of the lunette trench.

A small gunflint (Fig. 19,a), gray in color, with a flat base and tapering unifacial sides, is nicely made, although with some percussion marks along one edge from firing. It measures $1.65 \mathrm{~cm}$ long and 1.8 $\mathrm{cm}$ wide. Its small size would indicate its use in a flintlock pistol, or Kentucky rifle. Its construction is probably of American origin.

A possible gunflint, reddish brown in color, has corners rounded in back and is crudely chipped. It measures $2.6 \mathrm{~cm}$ in length and $2.2 \mathrm{~cm}$ wide. The size would indicate it is for a flintlock rifle, such as a Baker or a musketoon.

A tan-colored gunflint (Fig. 19,b) with some bifacial work, has edges worked on all four sides. The flint measures $2.75 \mathrm{~cm}$ long and $2.25 \mathrm{~cm}$ wide. The size of this gunflint would indicate it is for a flintlock rifle of the early 19 th century, and it would fit a Baker rifle well. The tan-or-gray colored flint like this usually comes from England.

A quartzite or agate gunflint, clearish gray with black specks in it, is bifacially worked on three sides with a 1.1- $\mathrm{cm}$-thick rear base. The flint measures $2.9 \mathrm{~cm}$ long and $3.5 \mathrm{~cm}$ wide, and was the size used in flintlock muskets of the early 19th century such as the Brown Bess.

A honey amber-colored gun flint (Fig. 19,c), very fine quality with rounded rear corners and unifacial tapering on edges, measuring $2 \mathrm{~cm}$ long and $1.8 \mathrm{~cm}$ wide. The size would indicate it is for a holster pistol or carbine of the early 19th century, and the color and construction would indicate it to be of French origin.

A brown-colored, unifacial gunflint (Fig. 19,d) measures $2 \mathrm{~cm}$ long and $1.7 \mathrm{~cm}$ wide. There are some percussion marks along one edge where it has been fired. The size would indicate it is for a pistol or military carbine.

Twelve lead balls, one bronze ball, and a minié ball were recovered. Eleven of the lead balls were recovered from various depths in the lunette trench, and a lead ball, a bronze ball, and the minié ball came from the 1989 excavations.

A single lead ball (Fig. 19,e) measures $1.65 \mathrm{~cm}$ in diameter, or about a .64 caliber. The seam and sprue facet are clearly visible. Although there is some oxidation present, the ball does not appear to have been fired. This size of ball was used in many of the pistols, rifles, and carbines of the early 19th century.

A single lead ball measures $1.65 \mathrm{~cm}$ in diameter, or about a .64 caliber. The ball is partially distorted, but shows no signs of impact, although there are two flat planes on opposite sides of the ball which may indicate it was fired, possibly from a long range which produced little damage to the ball. The size is one in general use in pistols, some rifles, and carbines during the early 19 th century.

A single lead ball (Fig. 19,f) measures $1.75 \mathrm{~cm}$ in diameter, or about a .69 caliber. There is a heavily faceted area on one side that would tend to indicate a low velocity impact. This could possibly be due to the ball having been fired from a great distance, or possibly from the ball having been included in the burst as shrapnel from a howitzer shell. The size of the ball would be consistent with those fired from a Brown Bess musket, used by the Mexican forces in 1836.

An impacted lead ball measures $2.25 \mathrm{~cm}$ in diameter and is $1.15 \mathrm{~cm}$ thick. It is impossible to determine the caliber of the ball with accuracy, but it appears to be about a .70 caliber.

A lead ball measures $1.8 \mathrm{~cm}$ in diameter, or about a .70 caliber. Although some oxidation is present, the sprue facet is pronounced and clearly visible. There is no indication, however, that the ball has ever been fired. The size of the ball would be consistent with use in the Brown Bess musket. The balls were also placed in exploding howitzer shells during the 1836 attack.

A single lead ball measures $1.85 \mathrm{~cm}$ in diameter, or about a .72 caliber. The size is difficult to determine with accuracy because the ball is badly distorted. One side is flattened where the fired ball has impacted with high velocity. There is also some deterioration and flaking present. The size of the ball would indicate use in a Brown Bess musket or as shrapnel in a howitzer shell.

An impacted lead ball (Fig. 19,g) measures $2 \mathrm{~cm}$ in diameter and is $1 \mathrm{~cm}$ thick. It is partially flattened and distorted on one side where it has been impacted, and convex on the other. It is impossible to determine the caliber of the ball with accuracy, but it appears to be about a .69 caliber for a musket.

A single lead ball (Fig. 19,h) measures $1.5 \mathrm{~cm}$ in diameter, or about a .59 caliber. The ball shows some oxidation, but the seam and sprue cuts are clearly visible. There is no indication that the ball has been fired. This size ball was used in officers' flintlock pistols and rifles of the early 19th century. This size ball could also have been used in cavalry musketoons and some Baker Rifles.

A single lead ball measures $1.5 \mathrm{~cm}$ in diameter, or about a .59 caliber. The ball shows some facets and gouges on the surface as well as oxidation, but appears to be unfired. This size ball could have been used in some of the officers' flintlock pistols or rifles of the early 19 th century. This size ball 
Figure 19. Arms, Military Equipment, and Buttons. a, gray gunflint, pistol or Kentucky rifle; b, tan gunflint, Baker rifle; c, honey amber gunflint, pistol or carbine, French; d, reddish brown gunflint, pistol or carbine; e, lead ball, ca. .64 caliber, pistol, rifle, carbine; f, lead ball, ca. 69 caliber, Brown Bess size; g, impacted lead ball, ca. .69 caliber; h, lead ball, ca. .59 caliber, cavalry musketoon, some Baker rifles; i, lead ball, ca. .49 caliber, pistol or Kentucky rifle; j, lead ball, ca. .41 caliber, pistol or Kentucky rifle; k, minié ball, ca. .59 caliber, standard Union Civil War musket; 1 , lead ball, grapeshot for three-pounder cannon; $m$, bronze ball, grapeshot for sixpounder cannon; n, lead plug for mortar shell; o, 4-gauge shotgun shell, English; p, brass equipment hook for Baker rifle; $p$, pewter coat button; $r$, pierced, domed button; $s$, brass three-piece bullet button; $t$, brass two-piece bullet button; u, brass coat button, U.S. military officer; v, brass cuff button; w, silver-plated brass three-piece cuff button; $x$, pewter two-piece flat cuff button. Shown actual size. 


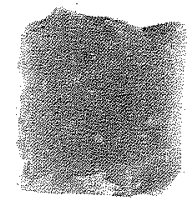

a

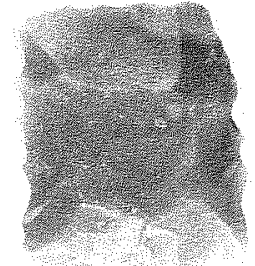

b

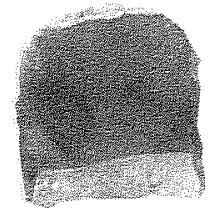

C

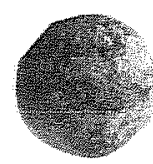

h

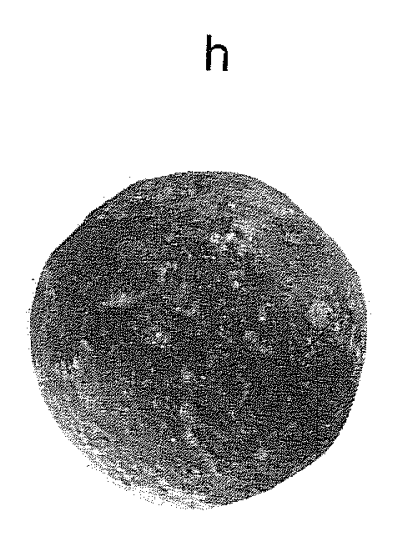

m

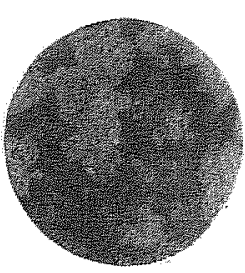

$q$

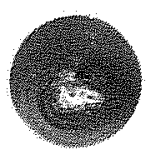

v

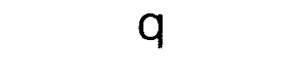

.

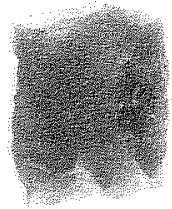

d
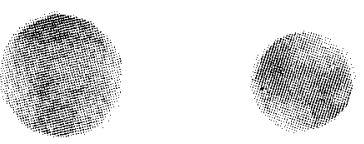

j

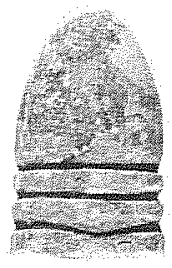

k

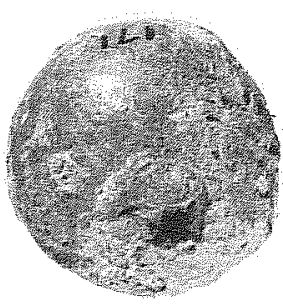

o
S

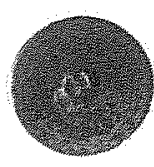

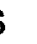

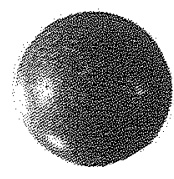

t
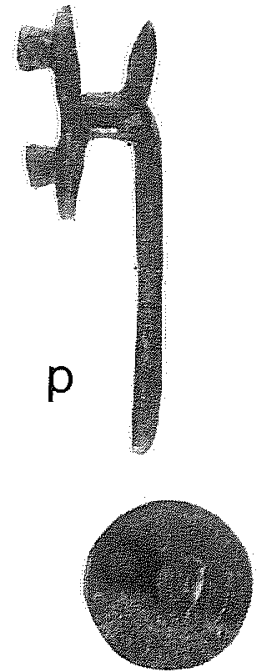

$u$

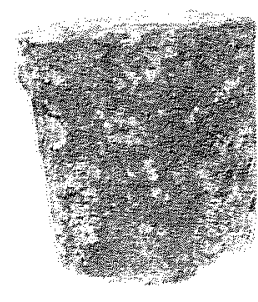

$n$

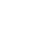

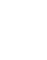
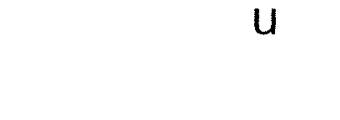
could also have been used in cavalry musketoons and some Baker Rifles.

A single lead ball (Fig. 19,i) measures $1.25 \mathrm{~cm}$ in diameter, or about a .49 caliber. The ball shows a single seam and traces of a sprue. Although some oxidation is present, the ball appears to be unfired. This size ball would have been fired in a flintlock pistol carried by officers, or possibly a Kentucky rifle.

A single lead ball (Fig. 19,j) measures $1.05 \mathrm{~cm}$ in diameter or about a .41 caliber. A single seam is visible around the ball, which is very well cast. There is no indication of the ball having been fired or impact marks visible. The size of the ball would indicate it was used in one of the flintlock pistols carried by officers, or possibly in one of the Kentucky rifles.

A single lead minié ball (Fig. 19,k) measures 2.55 $\mathrm{cm}$ long and about $1.5 \mathrm{~cm}$ in diameter, or about a .59 caliber. It has a three-groove base with a dent on one side. It appears unfired as it has no rifling grooves or percussion impact marks. The piece appears to be the standard ammunition of the Union Civil War period rifled musket. A total of 20 fragments of lead slag and sprue was recovered from the lunette trench, indicating the manufacture of musket and pistol balls somewhere in the vicinity.

A single lead ball (Fig. 19,1) measures $2.75 \mathrm{~cm}$ in diameter. A flattened impact area on one side measures $2.3 \mathrm{~cm}$ in diameter. A concave depression is on the opposite side where the sprue was cut. There is some calcification over all. This was probably grapeshot for a three-pounder cannon.

A single bronze ball (Fig. 19,m) measures $3.3 \mathrm{~cm}$ in diameter. Some calcification and oxidation are present. There are no indications of percussion. This is probably grapeshot for a six-pounder cannon.

Two bronze shell fragments and a lead plug recovered during the excavations may have been fired by howitzers located at the Mexican siege works in La Villita excavated by the CAR in 1985 (Labadie 1986). Similar shell fragments were excavated in front of the Alamo church in 1977 (Eaton 1980:64, Fig. 16,a).

A lead plug (Fig. 19,n), taperes in shape from a 2.4-cm-top to a $1.9-\mathrm{cm}$-base and is $2.5 \mathrm{~cm}$ long. Down the center is an irregularly shaped oval hole, $0.6 \mathrm{~cm}$ at the top and $0.3 \mathrm{~cm}$ at the bottom. The plug has been cast in two halves, and a longitudinal seam is visible on both sides. The hole down the center was for the measured powder charge of the fuse to control the timing of the burst. It is highly likely that this was a fuse plug for one of the 7-inch-bronze howitzer shells fired at the Alamo by the Mexican forces in 1836. The plug exactly fits the hole in a complete howitzer shell recovered at the Mexican siege works several blocks to the south in La Villita (Labadie 1986:73, Fig. 21,d).

A bronze howitzer shell fragment is irregular in shape, $3.5 \mathrm{~cm}$ long, and $1.6 \mathrm{~cm}$ wide. One end is twisted and shows considerable stress marks. All is covered throughout with oxidation. The fragment is part of a 7-inch howitzer shell.

A bronze howitzer shell fragment has a smooth surface on one end and irregular edges throughout the rest. It measures $2.1 \mathrm{~cm}$ long and $1.7 \mathrm{~cm}$ wide, tapering to a point. The fragment is $0.8 \mathrm{~cm}$ thick, and covered throughout with oxidation. The fragment is part of a 7-inch howitzer shell.

A brass shotgun shell head (Fig. 19,0) is $3 \mathrm{~cm}$ in diameter and $1.15 \mathrm{~cm}$ high. The paper shell case is missing, and iron oxide is present inside the shell head. A 0.75 centerfire primer is present and has been fired. The headstamp present around the head in raised letters is "ELEY BROS." at the top and "LONDON" at the bottom. On each side of the primer is "No 4;" this is the size of the cartridge, a 4-gauge shotgun shell of English manufacture, probably dating from the 1870 s.

A brass equipment hook (Fig. 19,p) is $4.45 \mathrm{~cm}$ in length and $0.85 \mathrm{~cm}$ wide. The bottom portion is only $2.25 \mathrm{~cm}$ in length and contains two brads that were once attached to leather. The lower portion is attached to the upper by an $0.3 \mathrm{~cm}$ bridge. The rear part of the upper portion has a slight indentation. This type of hook served as a stud on a bayonet scabbard to slip into a bayonet frog for attachment to the belt. The Bayonet, by Evans and Stephens (1985:24), shows a similar hook for a Baker Rifle bayonet, dating from ca. 1807.

A brass shako plate of the inverted tombstone variety, is about $13.5 \mathrm{~cm}$ high and $10.8 \mathrm{~cm}$ wide. The plate is extremely fragile and is stamped of very thin brass. There has been some damage sustained in two places along the side. The plate is curved at the bottom and flat along the sides and top. There are two holes above each other on each side for sewing to the shako front. There is a $0.6 \mathrm{~cm}$ fine border that extends around the edge of the plate. Within it is a scroll at the bottom with the words "MORELOS PERMANENTE." Above that is a laurel wreath which surrounds a Mexican eagle, facing to the left. His wings curve downward to a point, and he is holding a serpent in his beak. He is also standing on some prickly pear cactus leaves, below which is a horizontal feathered arrow, pointing to the left. The plate was worn on the shako of the Morelos Permanente Battalion of the Mexican infantry under General Co, who prepared the defenses of 
the Alamo in October and November 1835 (Sanchez Lamego 1968:9).

All metal buttons recovered during the two excavations have been included in this section, but in actuality many of them could have been used by either civilian or military persons. By far the largest number of them can be dated to the late 18th to early 19 th century, and all but one came from the fill in the lunette trench.

A one-piece flat pewter coat button (Fig. 19,q), cast with separate shank, which is missing has no back mark or design on the obverse. The button is very thin (about $0.15 \mathrm{~cm}$ ) and is $2.55 \mathrm{~cm}$ in diameter. Some oxidation is present throughout. The missing shank was probably of iron. This type of button was worn on late Spanish colonial coats, by military and civilians. The unusual one-piece button with separate shank has been dated as pre-1840 (Wyckoff 1984:xii) and probably first appeared in the late 18th century.

A one-piece flat pewter button with cast shank, is badly broken in two major pieces and is in very poor condition. The end of the shank is missing, but the base remains. It is badly oxidized, but appears to measure $2.2 \mathrm{~cm}$ in diameter. No design or back mark is visible. This type of button frequently was used on both military and civilian coats of the 18th and early 19 th centuries.

A one-piece flat pewter cuff button with the shank molded as one piece, is broken across one side with numerous stress cracks present. Some oxidation is present throughout. No back mark or design is visible. This style of button was worn on the cuff of coats or down the front of waistcoats by both military and civilians in the late 18th and early 19 th centuries.

A two-piece pewter pierced domed button (Fig. 19,r) is $1.35 \mathrm{~cm}$ in diameter and $0.9 \mathrm{~cm}$ thick. The iron shank is separately applied to the back. The design on the obverse is of a circle and pierced 6-pointed star, with six 8-petaled flowers between the arms. Above the points of the star are six holes, all surrounded by a rope border. Six similar flowers and bridged arches appear along the sides and reverse, with pierced areas between each one. This type of button could have been from a woman's dress or a gentleman's waistcoat. The style dates from the early 19 th century.

A three-piece bullet brass button (Fig. 19,s) is $1.6 \mathrm{~cm}$ in diameter and $1.15 \mathrm{~cm}$ thick. The back and shank are missing. No design is visible on the convex surface of the obverse side. This style of bullet button was confined to military uniforms of the General Staff and certain militia units, like the New Orleans Greys. The time period of this style is placed by Wyckoff (1984:64-65) as 1810 to 1832 , with the three 3-piece bullet falling into the latter part. There is some evidence that the usage extended to a somewhat later date in some areas. Another three-piece brass bullet button is $1.6 \mathrm{~cm}$ in diameter and $1.15 \mathrm{~cm}$ thick. The back and shank are missing. This is similar to the previously described specimen.

A two-piece brass bullet button (Fig. 19,t) is globular in shape with a thin wire shank still present. The button is $1.4 \mathrm{~cm}$ in diameter and $1.1 \mathrm{~cm}$ thick. No design or back mark is present, but the reverse shows numerous concentric circles around the shank where the brass has been drawn. This style of bullet button, because of its shape and construction, does not appear to be American in origin, and is probably Spanish or Mexican. They were worn on their General Staff uniforms, and would appear to date from ca. 1810 to 1830 .

A two-piece brass flat coat button (Fig. 19,u) has some traces of gilt plating remaining on the front and back. The button is $1.8 \mathrm{~cm}$ in diameter and 0.3 $\mathrm{cm}$ thick. No design is present on the front, but the reverse is marked with a circle, outside of which is marked "SCOVILLS/TREBLE GILT." Inside of the circle around the iron shank is a laurel wreath. This back mark for W. H. Scovill dates to 1827 to 1840 (Albert 1973:464), and means it was their highest quality gold plating. This type of button would have been worn on U.S. military officers' uniforms in the 1830s.

A two-piece flat brass cuff button (Fig. 19,v) has some traces of gold plating remaining on the back. The shank is broken and missing, although the base remains. The button is $1.5 \mathrm{~cm}$ in diameter. No design is present on the obverse, but the reverse has a back mark of a circle in which appears a wreath and "GILT." This type of button was in use during the early 19 th century, and was worn on the cuffs and waistcoats of both civilian and military dress.

Two fragments of brass one-piece flat buttons have their shanks missing, although the large one still has a portion attached. Neither has a design or back mark present. One is two-thirds intact and is $2.2 \mathrm{~cm}$ in diameter; the other has only the center section remaining, which is $2.7 \mathrm{~cm}$ in diameter. Both are representative of coat-sized buttons worn by both civilians and military from the later 18th and early 19 th centuries.

A three-piece convex brass cuff button (Fig. $19, w)$ has large amounts of silver plating present, although the iron shank is missing. The button measures $1.25 \mathrm{~cm}$ in diameter and $0.45 \mathrm{~cm}$ thick. No back mark is present on the reverse, but the obverse has a great deal of detail, consisting of a basket 
woven background, over which is a central circle and an outer circle. Condition is very good, except for the missing shank. Some light oxidation is present on the reverse. This type of button was generally worn on the cuff on a gentleman's coat, or down his waistcoat in the early 19th century.

A small iron button is ca. $1.6 \mathrm{~cm}$ in diameter. The button appears to be one piece, but very heavy oxidation prevents accurate measurement or observation. The context in which it was found, at the $20 \mathrm{~cm}$ near the north end of the 1989 excavations, suggests that this is a mid-to late-19th-century button.

A three-piece iron button is slightly concave, with the back and shank missing. It is heavily oxidized throughout, but appears to be $1.75 \mathrm{~cm}$ in diameter. No design is visible on the obverse, but the style is of the hunting button pattern, which was frequently worn on buckskin hunting shirts of the 1830s.

A three-piece iron button is slightly convex, with the back and shank missing. Heavy oxidation is present throughout. The button is $2.25 \mathrm{~cm}$ in diameter and was probably of the hunting motif style, worn on buckskin hunting shirts of the 1830s.

A two-piece flat pewter cuff button, is $1.5 \mathrm{~cm}$ in diameter (Fig. 19,x). The shank is missing from the back, and there is no back mark present except for two concentric circles without markings. The obverse contains a design of a six-petaled flower with stamens, surrounded by a laurel circlette, on a lined background. This type of button was generally worn on civilian cuffs and waistcoats of the late 18th and early 19 th centuries.

\section{CONSTRUCTION-RELATED ARTIFACTS}

All flat glass excavated during the two field schools was either $10 \mathrm{~mm}$ or $11 \mathrm{~mm}$ in thickness. The fragments were found at 40 to $50 \mathrm{~cm}$ in the lunette trench with the thinner fragments predominantly near $50 \mathrm{~cm}$. In the 1989 excavations, the glass fragments came from the upper levels and were scattered throughout the excavation area. There was no particular pattern to the depth distribution in relation to the thickness. On the whole, the $10-\mathrm{mm}$ sherds tend to be pale aqua and patinated, while many of the ll-mm sherds are clear glass. No particular significance for the site can be concluded from this artifact type.

Hand-forged (Fig. 20,a-c), cut (Fig. 20,d-f), and wire nails were recovered. As might be expected, the forged nails were only found in the contents of the lunette trench (Table 5), since they represent an earlier time period. Several pieces of hardware

\begin{tabular}{||l|c|c|}
\hline \multicolumn{3}{|c|}{ TABLE 5. NAIL RECOVERY } \\
\hline \multicolumn{1}{|c|}{ Type of Nail } & 1988 & 1989 \\
\hline Forged & 4 & \\
\hline Cut & 237 & 60 \\
\hline Wire & 1 & 2 \\
\hline
\end{tabular}

from the 1989 excavations are probably remnants of the city's use of the old barracks building in the late 19th century. A fragment of a heavy door hinge (Fig. 20,g) came from the first level near the south end. Half of a brown ceramic door knob (Fig. 20,h) was found in the first level near the center of the 1989 excavations. A large iron washer $2.7 \mathrm{~cm}$ across, came from the second level at the north end of the excavations (Fig. 20,i).

Fragments of Spanish colonial brick were found throughout the excavations. Primarily used as floor tiles or ladrillos, these bricks average $31 \mathrm{~cm}$ in thickness (Fox 1990) and were used at all the missions, including Mission Valero. They may also have continued to be made and used into the early 19th century in downtown San Antonio.

An interesting variation is a fragment of slightly curved tile (Fig. 20,j), $1.5 \mathrm{~cm}$ thick, that appears to be part of a canal or roof drain. Those now at the missions and recorded in early photos of San Antonio appear to be made of wood or stone, but ceramic canales were also used during the Spanish colonial period. The clay is identical to that of the bricks, and striations on both faces are parallel to the axis of the curve of the object. Ceramic canales may have been installed in the barracks building at some point in its history. Small fragments of yellow and red brick were also found at the north end of the 1989 excavations, perhaps reflecting the city's 19th-century repairs of the old barracks building.

Eighty-three fragments of carbons from arc lights were recovered, 80 from the upper levels in 1989, and three from the first level of the east-west fortification trench fill in 1988. Carbons represented were of two sizes, some 7/16 of an inch (Fig. 20,k) and others 9/16 of an inch (Fig. 20,1) in diameter. Nearly all were broken, except one of the larger diameter carbons which is three inches long. When newly installed, this would probably have measured ca. six inches in length. The tips of both carbon sizes were badly eroded, and both sizes bore green stains to within one inch of their tips, as if they had been jacketed in copper. 

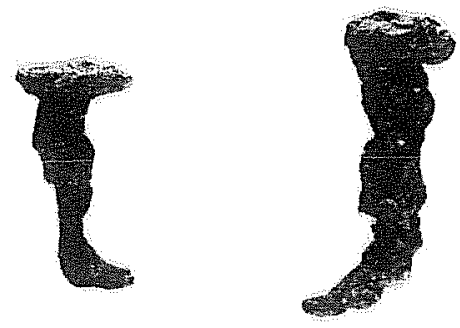

a

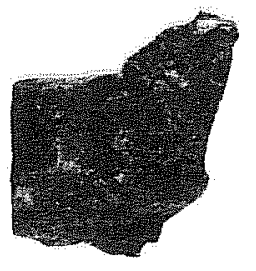

g

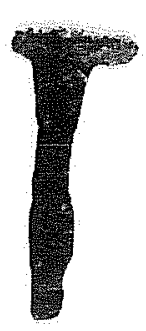

C d
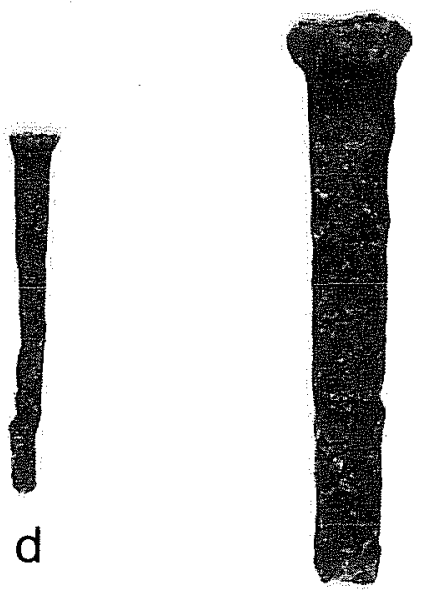

e

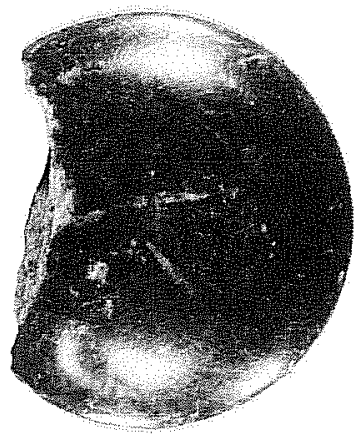

h

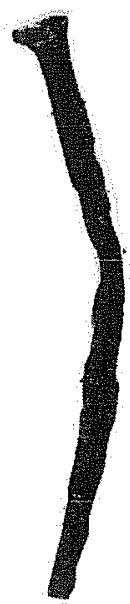

f

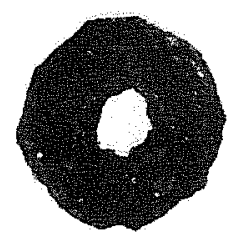

i

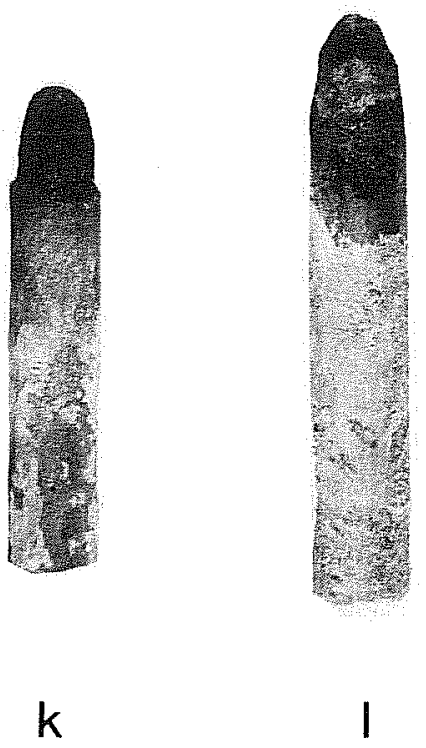

k

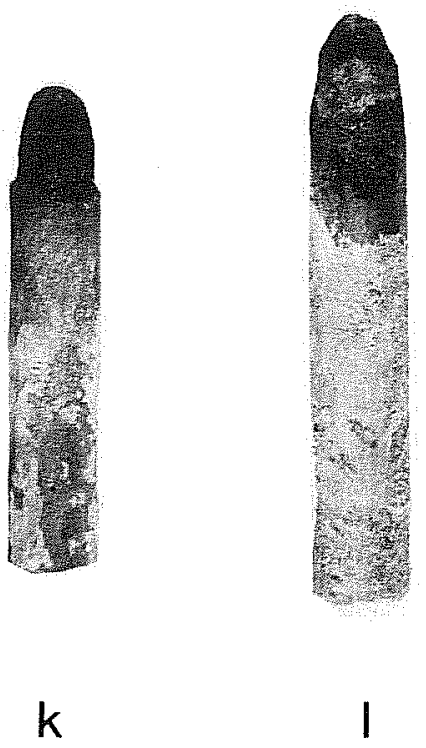

5

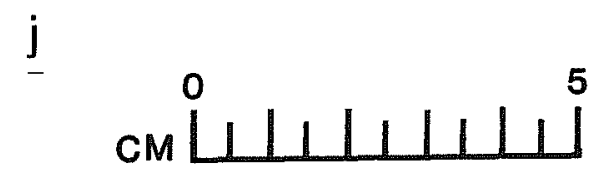

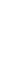

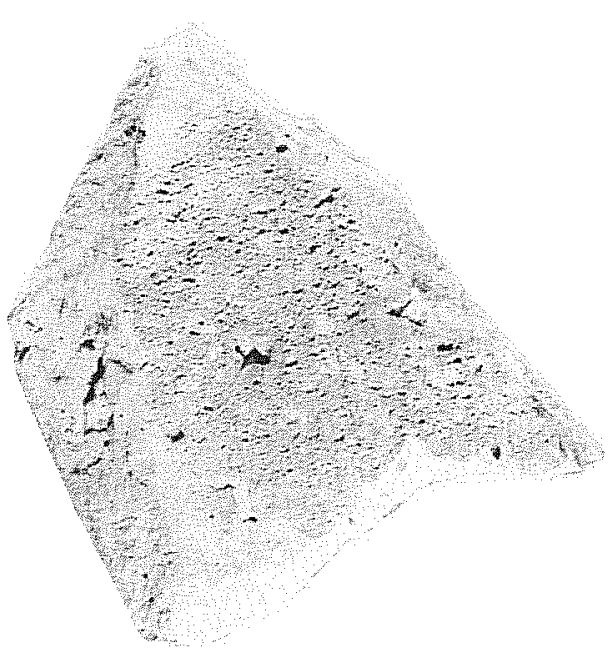

Figure 20. Construction-Related Items. a,b,c, hand-forged nails; d,e,f, cut nail; g, hinge fragment; h, ceramic door knob; i, heävy iron washer; j, curved tile, possible canal fragment; $\mathrm{k}$, arc light carbon, 7/16 inch diameter; 1 , arc light carbon, $9 / 16$ inch diameter. 
In 1810 , Sir Humphrey Davy used a 2000-cell battery to pass current through two charcoal sticks four inches apart to produce "a brilliant, arch-shaped flame, thereafter call the arc lamp" (Encyclopaedia Britannica 1954:105A). The first public lighting of this sort in the United States was in 1879 when the city of Cleveland installed 12 carbon arc lamps in the public square (Luckiesh 1940:114-130). The San Antonio Electric Company, chartered February 9, 1881, began operations in March 1882 by supplying 10 arc lights on Alamo Plaza (City Public Service 1976:2; Hemion 1978:31).

At first, arc lamps used direct current, which necessitated a larger diameter positive carbon and a smaller negative carbon (van Amerongen 1967:101). About 1890, it was discovered that alternating current, using equal-sized electrodes, was more efficient for use with long distribution lines. Between 1890 and 1893, direct current equipment in San Antonio was gradually converted to alternating current (City Public Service 1976:2). Apparently the carbons recovered from Alamo Plaza represent this transition period, since two sizes were found, of which the majority were the smaller diameter variety. Distribution of the carbons within the 1989 excavations suggests that one of the arc lights was probably located toward the north end of the excavation area.

\section{LITHIC ARTIFACTS (Herbert G. Uecker)}

This section presents the results of the analysis of 859 stone artifacts (Table 6) obtained during archaeological excavations at the Alamo in San Antonio, Texas. The sample analyzed includes both chipped stone artifacts and chert hammerstones that are attributed to Indian production and use. The excavations were performed near the south courtyard wall in 1988 and 1989, and the analysis was performed at the Archaeology Laboratory of The Center for Archaeological Research, The University of Texas at San Antonio (CAR-UTSA) in 1990.

Also included here are background information and commentary from the archaeological literature on historic period stone artifacts, primarily those from mission sites. For those unacquainted with such topics, excellent outlines of the basic principles of Indian stone tool manufacture and use and general definitions of relevant terms are located in Hester (1980:90-93), Crabtree (1982), and Turner and Hester (1985:15-39). For meanings of the terms used herein see Lithic Categories and Definitions and explanations throughout the text.

Archaeologists have developed standard methods of analysis for stone artifact samples; thus, their reports usually include some or all of the following elements (T. R. Hester personal communication 1990): (1) tables that list the numbers and kinds of artifacts present in a given sample (called typologies); (2) lithic chronologies (age charts for stone tools) based on the types of tools present and their archaeological contexts; (3) inferences about specialized human activity areas within archaeological sites based on distributions of stone tools and debitage (chipping debris from tool manufacturing); (4) inferences about manufacturing processes and stages for stone tools (called technological analysis); and (5) inferences about stone tool form and use based on very precise measurements or other specialized laboratory techniques, such as microscopic edgeware studies. Most of the methods used by archaeologists to investigate these topics were developed during studies of prehistoric lithics. They have also been applied to lithics from some historic sites and from a few Texas mission sites (cf. Schuetz 1969, Tunnell and Newcomb 1969, Gilmore 1975, Fox 1979, and Corbin et.al. 1980).

A search of the CAR-UTSA libraries and files revealed that published accounts that include detailed breakdowns of lithic artifacts from Texas historic sites are rare. Because of this scarcity, and due to project scope and budget limitations, the following research options that might otherwise have been pursued were excluded: comprehensive comparison of the $41 \mathrm{BX} 6$ lithics with other published lithic artifact analyses; (2) details analyses (for comparative purposes) of lithic artifact samples from other historic sites; (3) expanded literature search of publications other than those contained in the CAR-UTSA libraries; (4) investigation of primary sources, such as 18th century archival documents concerning the Spanish mission Indians and their stone tool technologies, and (5) sophisticated (time/labor intensive) laboratory analyses, such as microscopic edgeware studies. A selection of the stone artifacts found in the 1988/1989 Alamo Plaza excavations was typed and enumerated (Table 6), and a modest comparative study was undertaken. Comparisons are presented in Table 7, which shows the percentages of primary, secondary, and tertiary flakes in lithic artifact samples from several south and central Texas prehistoric, historic mission, and mission-related sites. 
CHIPPED STONE ARTIFACTS:

$\begin{array}{ll}\text { CORES } & \\ & \text { Partially Corticate } \\ & \text { Decorticate }\end{array}$

CHERT HAMMERSTONES

\section{FLAKES}

Primary

Cortex Platform

Decorticate Platform

Secondary

Single Facet Platform

Multiple Facet Platform

Cortex Platform

Lipped or Biface Thinning

$\begin{array}{rr}35 & 21 \\ 9 & 5 \\ 33 & 17 \\ 7 & 5\end{array}$

Tertiary

Single Facet Platform

44

31

Multiple Facet Platform

Lipped or Biface Thinning

Blade Flakes

Partially Corticate

Decorticate

Modified

Trimmed

Partially Corticate

Decorticate

Modified

Trimmed

\section{CHUNKS}

Partially Corticate

Decorticate

\section{UNIFACES}

Thick

$$
\text { End Scrapers }
$$

Thin

Flake Perforators

BIFACES

Thick

End Scrapers

Side Scrapers

Unidentified

Lateral Fragments

Elongate Tools

Thin

Unstemmed

Proximal Fragments

Distal Fragments

Medial Fragments

3

2

Lateral Fragments

Unidentified

Stemmed

Dart Points

Arrow Points 


\section{TABLE 7. FLAKE COMPARISONS}

Comparisons of Proportions of Primary, Secondary and Tertiary Flakes in Samples from Selected Historic and Prehistoric Archaeological Sites in Texas. Data shown for sites is taken from the following sources: 41 BX 271: Jones et. al. (1975); 41 KE 49: Kelly (1975); 41 VV 1251: Uecker (1991) 41 BX 3 (Mission San Jose), 41 BX 5 (Mission San Juan Capistrano), 41 BX 6 (the Alamo, 1973 excavations), and 41 BX 12 (Mission Concepcion): Fox (1979); 41 BX 228: Uecker (1979); 41 WN 30 (Rancho de las Cabras, a probable visita, or sub-mission [Fox 1983:113] of Mission Espada): Labadie (1983). The figures for 41 BX 12 are listed separately (from Scurlock and Fox 1977) and included in Fox's (1979) combined totals for four mission excavations. Percentages have been rounded to the nearest whole numbers.

\begin{tabular}{|c|c|}
\hline $\begin{array}{l}\text { Site No. (year investigated) } \\
\text { (temporal context) }\end{array}$ & $\begin{array}{c}\text { Relative Percentages } \\
\text { of Primary, Secondary, } \\
\text { and Tertiary Flakes }\end{array}$ \\
\hline $\begin{array}{c}41 \text { BX } 228 \text { (1979) } \\
\text { (prehistoric) }\end{array}$ & $1 \%$ to $19 \%$ to $80 \%$ \\
\hline $\begin{array}{c}41 \text { BX } 271 \text { (1974) } \\
\text { (prehistoric) }\end{array}$ & $7 \%$ to $20 \%$ to $73 \%$ \\
\hline $\begin{array}{l}41 \text { BX } 271 \text { (1979) } \\
\text { (prehistoric) }\end{array}$ & $5 \%$ to $20 \%$ to $75 \%$ \\
\hline $\begin{array}{l}41 \mathrm{KE} 49 \text { (1975) } \\
\text { (prehistoric) }\end{array}$ & $9 \%$ to $21 \%$ to $70 \%$ \\
\hline $\begin{array}{l}41 \text { VV } 1251 \text { (1989) } \\
\text { (prehistoric) }\end{array}$ & $2 \%$ to $45 \%$ to $53 \%$ \\
\hline $\begin{array}{l}41 \mathrm{BX} 6(1988) \\
\text { (historic) }\end{array}$ & $9 \%$ to $41 \%$ to $50 \%$ \\
\hline $\begin{array}{l}41 \text { BX } 6 \text { (1989) } \\
\text { (historic) }\end{array}$ & $15 \%$ to $40 \%$ to $45 \%$ \\
\hline $\begin{array}{c}41 \mathrm{BX} 12(1971-72) \\
\text { (historic) }\end{array}$ & $3 \%$ to $57 \%$ to $40 \%$ \\
\hline $\begin{array}{c}41 \text { WN } 30 \text { (1981) } \\
\text { (historic) }\end{array}$ & $22 \%$ to $49 \%$ to $29 \%$ \\
\hline $\begin{array}{c}\text { Combined Total from: } \\
41 \text { BX } 3 \text { (1968 and 1974) } \\
41 \text { BX } 5 \text { (1967) } \\
41 \text { BX } 6 \text { (1973) } \\
41 \text { BX } 12 \text { (1971 and 1972) } \\
\text { (historic) }\end{array}$ & $1 \%$ to $64 \%$ to $35 \%$ \\
\hline
\end{tabular}




\section{Lithic Categories and Definitions}

The following definitions were employed in the analysis. With the exception of that for burned chert (conceived by Uecker), they were derived or adapted from Crabtree (1972), Mallouf (1976), and Shafer (1969):

Core A nodule, pebble, cobble, or slab from which a flake or flakes has been intentionally removed.

Flake A piece struck from a core retaining all or part of the striking platform utilized for their removal.

Primary Flake A flake retaining cortex over its entire external or dorsal surface. Results from initial testing and/or decortification of a core. As defined in this study, a primary flake may have a striking platform devoid of cortex.

Secondary Flake A flake retaining from $1 \%$ to 99\% cortex on its external or dorsal surface as a result of having been struck from a partially decorticate core.

Tertiary Flake A flake devoid of cortex on the external or dorsal surface, including the striking platform.

Cortex-Platform Flake A flake with platform of unmodified weathered cortex. Because of platform cortex, such flakes are classified as secondary flakes.

Single-Facet Platform Flake A flake with platform consisting of a single removal scar (facet) produced by previous flaking.

Multiple-Facet Platform Flake A flake with a platform consisting of two or more facets produced by previous knapping.

Lipped Flake or Biface Thinning Flake Typically, these flakes have multifaceted, lenticular shaped striking platforms and a characteristic lip or ridge which is at right angles to the axis of removal on the ventral side. The striking platforms are bifacially prepared and multifaceted. The dorsal side of the flake is multifaceted and rarely exhibits cortex.

Blade A flake with parallel or sub-parallel lateral edges; the length being equal to, or more than, twice the width. One or more parallel ridges or scars run nearly the length of the dorsal surface. Cross-sections are plano-convex, triangulate, sub-triangulate, rectangular or trapezoidal. Associated with prepared core and blade techniques; not a random flake.

Chip A portion of a flake which due to breakage, crushing or shattering has no platform. Further subdivided into corticate and decorticate.

Chunk Fragment with or without cortex showing no striking platform and no force rings (bulbs of percussion) emanating from the direction of applied force. Thickness approaches maximum length and width. Too small to be a core, too large and massive to qualify as a chip. Further subdivided into corticate and decorticate.

Burned Chert Any piece of chert exhibiting any or all of the following: obvious discoloration (usually blackening, graying, or reddening), mottling, cracking, or surface erosion or roughening (usually fine textured) which is readily attributable to either direct or indirect heating. In this study, burned chert artifacts were first classified and counted whenever possible by specific type such as flake, chip, etc., and then counted a second time under the burned chert category. The burned chert category was not further subdivided.

Modified Flake or Chip A flake or chip that may have been used as a tool. Such use is evidenced by minute nicking, battering, or sheen along the edges of the flake or chip.

Trimmed Flake or Chip A flake or chip demonstrating intentional edge preparation through removal of a uniform series of tiny flakes. Distinguished from Modified Flakes and Chips in 
that human alteration of the piece is unquestionable (Mallouf 1976).

Biface An artifact or artifact fragment bearing flake scars on both faces.

Uniface An artifact or artifact fragment bearing flake scars on only one face. Distinguished from a modified flake or chip in that the unifacial flaking was directed at the overall shaping of the artifact as well as creating a working edge.

\section{Background and Commentary}

\section{General Considerations}

Whenever chipped stone tools were made by humans, certain types of waste particles (flakes and chips) were produced and strewn about the floor of the work area in distinctive patterns. Sometimes these patterns were gradually buried by natural soil deposits and were relatively well preserved, even for thousands of years. Such situations result in what archaeologists call primary cultural deposits. Because of the natural physical and mineralogical properties of the stones (cherts and flints) used to make the tools, the waste particles form distinctive types, including among others, primary, secondary, and tertiary flakes. The ratios of these flake types in a given sample of chipping debris are significant for archaeologists because they fall into statistical patterns that may be used to draw logical inferences about the types of tools that were being made, how they were made, and other activates of the people who made them (cf. Shafer 1969; Crabtree 1972; Fox et.al. 1974:25; Mallouf 1976).

For example, tertiary flakes are the last flakes to be removed during the making of chipped stone tools; thus, the presence of high proportions of tertiary flakes in a sample indicates that the sample came from an area where tools were undergoing final shaping and thinning. The generally higher proportions of such flakes found in prehistoric Indian sites relative to those found in historic-age deposits at mission and other historic sites (Table 7) may be explained in several ways: (1) smaller percentages of bifaces (finished chipped stone tools) and/or greater percentages of simple tools, such as flakes that were used without additional shaping for cutting or sawing, were produced at the mission and other historic sites than were produced at the prehistoric sites (Hester [1977a:11] has alluded to the large number of "casual tools" made on modified flakes and blades found at Texas missions.); (2) the raw materials available for chipped stone tool production were of poorer quality or in shorter supply at the sites having substantially fewer tertiary flakes than at the other sites; (3) the locations within the missions and other historic sites where finished stone tools were produced have been systematically missed in archaeological excavations, or the tools used there were finished elsewhere and imported; or (4) contemporaneous competing European technologies, including European stone tool manufacturing (Fox 1979:35-40), substantially influenced the mission Indian's chipped stone tool forms.

Unfortunately, it is virtually impossible for archaeologists to obtain lithic artifact samples that are perfectly preserved, and this is especially true at mission sites (Hester 1977a:12). Generally, the smaller the sample size, the greater the potential for error; however, just because a sample is relatively large does not mean that it has not been disturbed by natural processes or human activities. Subconscious predispositions, errors, or intentional selectivity in the collection of samples during archaeological investigations are only a few examples of secondary sources of sampling bias. Considering both the singular and combined effects of all of the potential sources of error, the chances of making valid, mathematically precise interpretations of technologies and attendant human behavioral patterns from samples of archaeological lithics are slim. Fortunately, in lithic analysis a high level of refinement is not necessary to arrive at some tentative yet potentially important interpretations that may function as first steps toward later, more cogent explanations. Such derivations are combined with background information from the archaeological and historical literature on the missions to generate the implications and conclusions expressed in this section.

\section{The Mission Context}

The history of archaeological research on the Texas missions accounts, to a large degree, for the present small data base for comparisons. Systematic archaeological work at the Texas missions was only begun in the early to mid 1960 s (Fox 1979:1). Until the mid to late 1970s, debitage apparently was not usually collected during such investigations, or in the few cases when it was collected, procurement and proveniencing methods were erratic (A. Fox personal communication). 
Often, little if any analysis was undertaken or results were never published (Hester 1977a:10). It was only during the late 1970s and the 1980s that the analysis of chipping debris from historic archaeological sites in the Texas and San Antonio areas and the publication of the results began to occur with any frequency.

In the late 1970 s, Hester compared the salient characteristics of the Indian lithic technologies of several missions in Texas and Mexico, and assessed the state of knowledge about such technologies and its potential for future enhancement:

We are almost totally ignorant of lithic tool kits for the mission period. This stems from either a lack of proper recording, the fact that Indian quarters were often reused by later populations in and around the missions, and the fact that much of the lithic sample comes from scrambled midden contexts.

The unfortunate aspect of mission lithic studies is that the available sample is so very limited. There are a finite number of missions, and within these complexes, only certain areas that yield Indian debris, including lithics. At many missions, like the Alamo, the Indian quarters were destroyed by construction long ago. At other missions, the Indian quarters were excavated with insensitive techniques during the WPA days. At more recent excavations, there has been selective collecting, and even more selective description and reporting. In essence, there will be little opportunity in the future to collect and analyze data on the mission lithic technology. This is why it is imperative. . .that our field recording techniques be superior, and that our descriptions and analyses be published in full, making possible more valuable comparative statements in the future [Hester 1977a:12].

In spite of subsequent general improvements in collecting and reporting, the literature search undertaken for this report discovered less than a dozen site publications in which the lithic sections were viably comparable. Again, detailed comparative analyses of the lithic data in these works were not performed for this report due to project time limitations (see Fox 1979 for an example of such analyses).

Several characteristics of the mission Indian cultures that are relevant to the interpretation of mission Indian lithics have been addressed both in site reports and in more general works. There are numerous references to the notion that certain aspects of the lifeways of local Indians, including hunting and butchering practices and the attendant manufacture and use of lithic tools, continued relatively unchanged from the prehistoric into the historic period; for example:

The aboriginal hunting and gathering groups gathered into the 18th century missions of Texas and northeastern Mexico brought with them a long tradition of stone tool manufacture. . .one native tradition, that of the production of stone tools, continued throughout the mission era [Hester 1977a:9].

It seems logical that European tools and mission technology quickly replaced the hunting and gathering technology of native groups. One technological system which was retained at least for a short period was the manufacture and use of lithic tools [Fox 1979:1].

Interestingly enough, the butchering marks found on the cow bones [excavated from San Jose Mission in 1974] indicated that the butchering techniques of the mission inhabitants were similar to those of prehistoric peoples in Texas. . . [Fox 1983:103]

Missions [in the Rio Grande delta area] were never able to produce enough food by irrigation agriculture to feed resident Indians, who often left the mission to find food by hunting and gathering [Salinas 1990:162]

Thus, it is frequently acknowledged that both prehistoric and historic Indian chipped stone tool inventories in south and central Texas were generally similar and relatively simple (see Hester 1977a for commentary on variability in mission lithic tool assemblages and possible ramifications.). They consisted essentially of projectile points for 
tipping spears and arrows, and several varieties of cutting, sawing, scraping, planing, shaving, boring, perforating, and/or engraving tools that had fairly standard morphologies. Many if not most of the non-projectile-point tool types were flakes that were struck from cores and only slightly altered prior to use. Although Labadie (1983:67) and Fox $(1979: 35,37)$ found little evidence for the presence of blade and bipolar technologies in lithic samples from San Antonio area missions and mission-related sites, Lohse (1991:31-32) believed that blade technology was in use at the Alamo mission in the eighteenth century. Hester (1977a:11) described the occurrence of a substantial number of blades in samples from San Bernardo, San Lorenzo, and San Juan Capistrano Missions. He attributed the presence of such blades at the missions of south Texas and northern Mexico to the continuation of local and regional prehistoric blade-oriented industries.

The results of recent excavations at the Shanklin site (41 WH 8; an historic Indian site in Wharton County, Texas) supported the concept of the general continuity of Indian chipped stone tool morphologies and manufacturing techniques from prehistoric into historic times. Guerrero arrow points, along with many other types of artifacts that had previously been excavated only at mission sites, were found at the Shanklin site in a non-mission historic context within the combined south and central Texas areas for the first time (Hudgins 1986). According to Labadie (1983:67) the Guerrero type has also been excavated from prehistoric contexts; however, in both Hester (1977b:6) and Turner and Hester (1985:177), the temporal range of the Guerrero type is confined solely to the historic period.

Various scholars refer to ethnographic and ethnohistorical accounts concerning mission Indian tools and related topics, and archaeological finds of tools and chipping debris at the mission sites tend to authenticate them:

The arrows [of the Rio Grande Comecrudos as described in 1738 by Ladron de Guevara], which were carried in quivers, had shafts of reed (carrizo), foreshafts of heat treated wood, and points made of flint or glass. Presumably the glass came from bottles collected along the seashore. . . Gatchet's Rio Grande Comecrudo vocabulary collected in 1886 refers to a scraping tool used to smooth a wooden stick, and there are words for knives used for various purposes, including the cutting and trimming of hides. . .Cabeza de Vaca. . was made to scrape animal hides, but he did not describe the tool used [Salinas 1990:126; emphasis added].

In general, the chipped stone sample [collected during archaeological excavations at four Texas Spanish mission sites] seems to be representative of a lithic technology concerned primarily with the production of flake-tools for use as projectile points and cutting, scraping, boring and engraving activities, all of which probably supplemented a Europeanintroduced technology of metal and stone. . . [Fox 1979:37]

The lithic material from the 1980 and 1981 field seasons [at Rancho de las Cabras] was analyzed and examined for use-wear by Labadie (1983), who assigned the material to groups similar to those used in Fox's (1979) study of lithic material from four Spanish Colonial missions in San Antonio, Texas [Taylor and Fox 1985:36].

The contamination of mission Indian chipped stone artifacts of the historic period with artifacts of prehistoric origins (and vice versa) and the influence of European lithic technologies on mission Indian lithics have been discussed at several points in the literature. It is generally agreed that the short spear or dart as a hunting instrument and weapon had become virtually obsolete among most Texas Indians by the beginning of the mission era (although Hester [1977a:11] cites some evidence to the contrary). Nevertheless, dart points, which are usually distinctively larger and heavier than arrow points, are often found directly associated with historic period mission artifacts, and several explanations have been offered: In a few cases, portions of the missions were constructed over portions of prehistoric Indian sites, and artifacts from the two periods have by one means or another become commingled (Fox 1979:29). Hester (1975:24-25, 1977a:10-11) suggested that (1) smaller dart point-like projectile points that were actually arrow tips and larger dart point-like knives made during historic times have been erroneously attributed by lithic analysts to the prehistoric 
period; and (2), the mission Indians collected prehistoric lithic artifacts as curios or for re-use.

In contrast to the notion of technological continuity implicit in most mission lithic samples excavated and analyzed to date is Fox's $(1979: 37,39)$ contention that the manufacturing of gunflints and strike-o-lites and perhaps of other unknown lithic tools by the European occupants of the missions may have influenced the lithic tool forms of the mission Indians significantly. Along somewhat similar lines, Campbell and Campbell (1985) warned against the use of documentary evidence as a basis for making assumptions about the character or contents of mission Indian lifeways. Their admonishments seem particularly relevant to chipped stone tool manufacturing practices:

For Indian groups associated with the historical park missions, some categories of culture are either missing from, or sparingly recorded in, documents. Little detail is given about how artifacts were made and used; about the methods of hunting, fishing, and plant food collection; or about how various kinds of foodstuffs were processed and cooked.

This dearth of information makes it virtually impossible to comment on specific changes in the cultures of Indians while they were in the San Antonio missions [Campbell and Campbell 1985:20].

Hester (1977a:11) had presaged the Campbells' observation in asserting that "there is no description of [mission Indian] lithic tool kits" in known Spanish inventories or records, and suggesting that the prospects of finding such descriptions in archival records were poor.

Using the history of the Rancho de las Cabras site as an example, T. N. Campbell (1985:51) has also pointed out that errors exist in both the early ethnographic literature and later interpretations concerning identification of Indians groups present at mission and mission-affiliated sites. Further archaeological work may be instrumental in clarifying which groups lived at the missions. Indeed, Hester (1977a:12) suggested that, as more detailed excavations and analyses of mission Indian lithic samples are preformed, it may be possible to discover or verify the identities of mission groups from lithic data alone due to the fact that characteristics that signal group affiliation are sometimes present in lithic assemblages.
Both T. N. Campbell and Salinas (1990:50) have noted the fact that, during the Spanish Colonial period many south Texas Indian groups, mostly the so-called Coahuiltecan speakers, moved from their more natural habitats in the surrounding country sides into the missions and presidios in both central and south Texas. Fox (1979), in general agreement with Hester (1977a:10), has explained the impact of this aggregation on lithic and other technologies of the Indians:
Spanish accounts indicate that most mission Indians quickly adopted a common language, dress and customs....all of which appear to have developed from a mixed Indian and Spanish Colonial heritage. The occurrence of relatively similar forms of chipped stone tools at different mission sites may represent a generally common lithic technology which developed to conform to a new cultural identity among mission [Indian] neophytes [Fox 1979:39-40].

Fox (1977a:16) has noted that there apparently was a scarcity of metal at missions in and near San Antonio during Spanish Colonial times that may have prompted the Spaniards to adopt the manufacture and use of chipped stone implements to some degree. She concluded that not all of the chipped stone tools and debris found at San Antonio mission sites was necessarily of Indian origin. Given that metal was scarce, it would have been especially important for the mission Indians to have a viable substitute raw material from which to make tools for routine utilitarian tasks (Hester 1977b:3). Faunal bones collected archaeologically at several mission sites indicate that the Indians living there were apparently still engaging in fairly regular hunting and gathering activities (cf. Rawn 1977:143-152, Hester 1977b:5). It would have been quite reasonable under those circumstances for them to have relied on their already-established technologies whenever possible.

Even though the sample of Indian chipped stone artifacts from the 1988/1989 Alamo excavations was obtained primarily from secondary archaeological contexts, it is qualitatively and quantitatively very similar to samples (as characterized in the archaeological literature examined) from other local mission excavations. As supported by the presence of seven chert hammerstones as well as by the general morphology of the debitage in the sample, the chipping technology used was basically percussion. The lack of internal standardization 
within mission lithic assemblages in general and the "rather careless, if not erratic, flake production sequence" at San Lorenzo observed by Hester (1977a:11) seem generally characteristic of the 1988/1989 Alamo lithic sample.

Numbers of primary and secondary flakes in the sample are equal to or greater than the numbers of tertiary flakes. Again, this is in marked contrast to flake ratios in many prehistoric site lithic samples, in which tertiary flakes usually outnumber the combined totals of primary and secondary flakes by more than two to one (Table 7). Very few blades were found. Flake tools and tool fragments (classified only as modified flakes or trimmed flakes in Table 7) are more numerous than finished bifacial tools and tool fragments by a ratio of almost $2: 1$. The combined totals of bifacial and unifacial tools and fragments of tools comprise just under $2 \%$ of the total number of all chipped stone pieces in the sample. The sample includes Guerrero and Perdiz arrow points, bifacial and unifacial scrapers, knives, saws, gravers, planes, perforators, and spokeshaves (Figure 21). All appear to be made of fairly good to excellent quality light gray to tan colored chert available at natural outcrops in limestone and in fluvial or alluvial gravel deposits in the San Antonio area. The San Antonio river bed is the source of chert most convenient to the Alamo mission.

All of the arrow points in the sample were found in the lunette-trench fill excavated in 1988. There is little doubt that the fill was used by General Cos' troops to make earthwork fortifications prior to the November, 1835, Battle of Bexar. The trash or midden piles that would have been just outside of the south gate prior to the fortification work by Cos' men were probably incorporated into the lunette berms and thus would also have been used as lunette-trench fill after the 1836 battle (A. Fox personal communication). Assuming the veracity of the latter assertion, and given the fact that most of the matrix removed by controlled archaeological excavations at the Alamo during the 1988 season came from the lunette-trench fill, it is likely that the provenience of the arrow points found is not the result of primary placement during the various 19th century battles that occurred there. Instead, because the excavated context of the arrow points is apparently a secondary one, their manufacture and use probably predates the 19th century and relates to hunting activities by mission Indians. Arrow points of historic origins have been found during several previous archaeological excavations at the Alamo in what are more likely to have been primary archaeological contexts near or within Indian living quarters or within the Convento. They have also been found in similar contexts at several of the other San Antonio missions, as well as at Missions San Bernardo and San Juan Bautista at Guerrero, Coahuila (Hester 1977:10)

\section{Conclusions}

The results of this analysis and literature search suggest that much further work is needed in the area of historic Indian lithic sampling, examination, and interpretation. To better understand past lithic technologies and related human behavior patterns, field proveniencing techniques at historic Indian sites need to be optimized in all future archaeological excavations to facilitate the association of chipped stone samples with particular manufacturing events. An inherent limitation to the attainment of this kind of refinement is the paucity of primary archaeological deposits at such sites. Historic period cultural deposits are often thin and even when they are contained in rare, relatively well-preserved depositional contexts, they can be difficult or impossible to distinguish. Also, within contract archaeology, especially at mission sites, the areas targeted for investigations are usually dictated by impending modern construction events and the time and talent that can be budgeted for lithic analyses is often severely limited. It is nevertheless possible that, through persistent efforts by archaeologists, more non-emergency or non-salvage archaeology will be funded, at least for a few of sites of unusual importance, such as mission sites. Perhaps it would also be prudent to break away from the practice of normative archaeology (that has often concentrated at historic sites exclusively on the documentation of architectural remnants or verification of archival and ethnographic accounts) and excavate less spectacular, non-architectural features, such as refuse piles. Such a basic change in tactics might result in the procurement of better overall samples of artifacts, including lithics. In spite of the fact that most of the Indian living quarters at Texas missions have been disturbed, it may still be possible to effectively apply these principles to other nearby areas:

... .it is quite likely that many of the Mission Indian household activities actually took place outside the confines of their small quarters. For instance, it appears that cooking fires were placed outside the houses, and following aboriginal tradition, the 


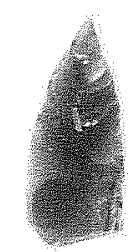

a

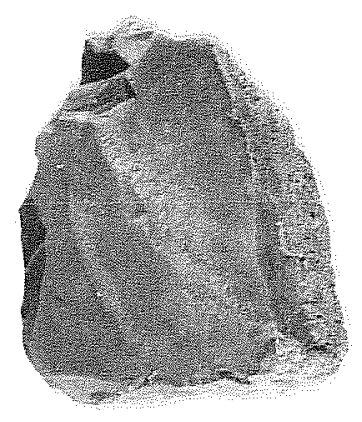

f

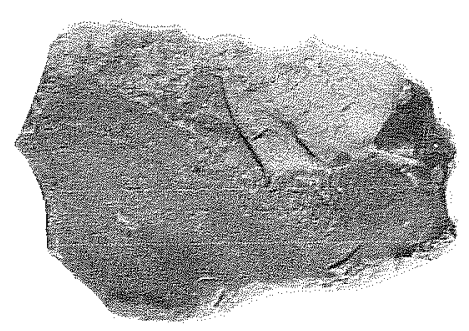

i

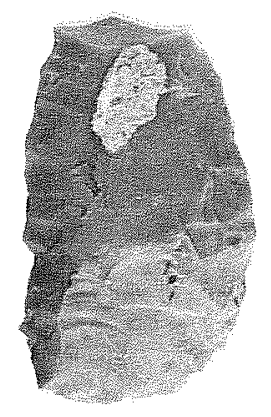

I

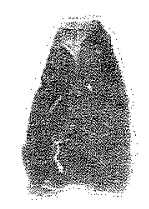

b

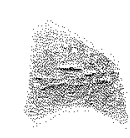

C

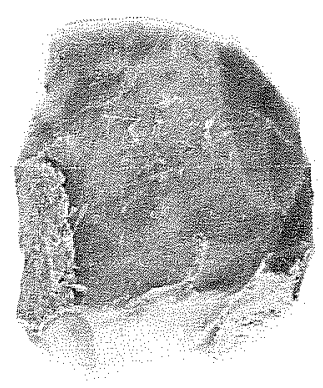

g

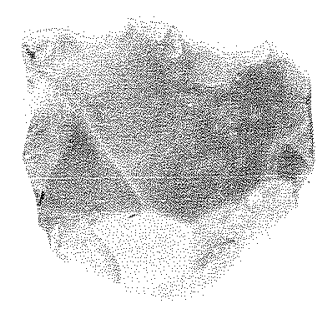

j
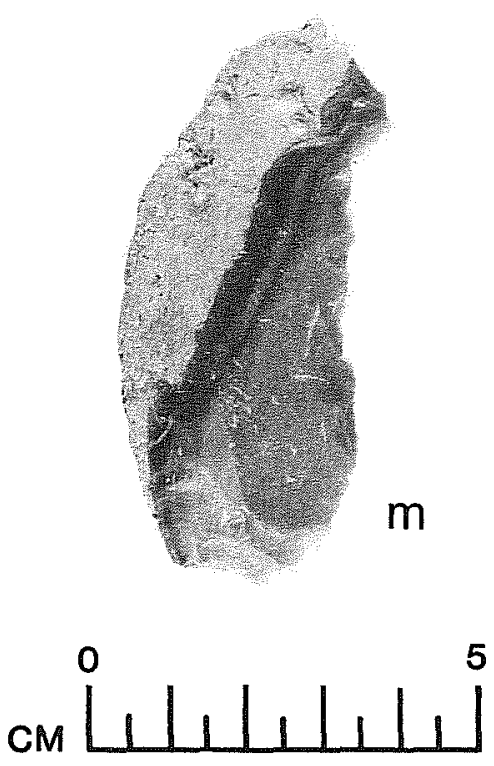
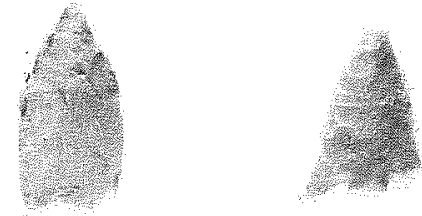

d

e

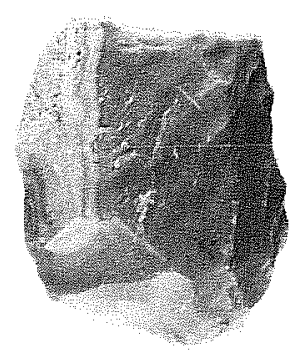

h

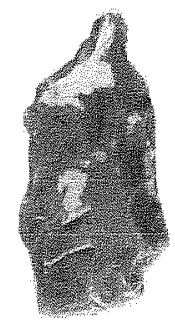

k

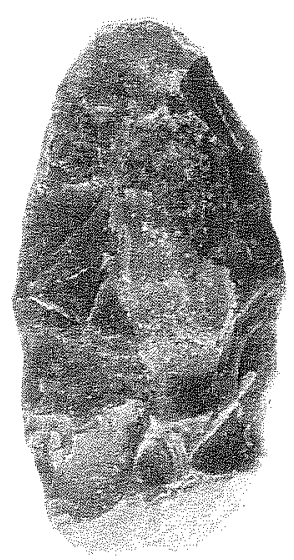

n

Figure 21. Selected Chipped Stone Artifacts from the 1988-1989 Alamo Plaza Lithic Sample. a, distal tip or arrow point preform; b-d, Guerrero arrow points and fragment; e, Perdiz arrow point, f-h, unifacial flake end scrapers; $\mathrm{i}, \mathrm{j}$, flake spokeshaves; $\mathrm{k}$, flake perforator or graver; l,n, thick bifacial tools; m, flake side scraper or knife. 
neophytes may have carried out many tasks, such as stone-working, in areas away from the structural remains [Hester 1977b:1].

\section{SUMMARY AND CONCLUSIONS}

A long and interesting history surrounds today's Alamo Plaza. Activities associated with the mission, the U.S. Army, and the growing city of San Antonio have all left evidence for the archaeologist to study and attempt to explain. Although the 1988 and 1989 field schools emphasized the military aspects of the Alamo's history, evidence of both the mission and city development periods were also recovered during the excavations. The objective of the 1988 field school - to discover the size and shape of the lunette trench - was fulfilled beyond the anticipations of the project's organizers, partially due to the extreme good fortune of the discovery of a preserved section of the trench located to the west of the excavation area which was revealed by the Tri-Party digging in South Alamo Street. In addition, the contents of the trench fill surpassed expectations, in variety and interpretational value relative both to the mission period and to the events of the 1835 and 1836 battles.

Some of the most important information obtained in these excavations is in the assortment of ceramics recovered from the lunette trench fill. While numerous excavations carried out in and around downtown San Antonio have produced early 19th-century whitewares (Schuetz 1969; Fox 1977a; Ivey 1978), confused contexts in which the sherds were found have not allowed confident dating of these wares. Since the ceramics in the lunette trench fill had to have been deposited there during the demolition of the fortifications, we can for the first time confidently conclude that the types and patterns represented arrived in San Antonio before 1836. The fact that the whitewares found during the previously mentioned excavations originated in England, and that they have been found in large quantities on Anglo-American sites farther east in Texas, has previously suggested to archaeologists working in San Antonio that they were brought in by the first Anglo-American settlers in this area after the Texas revolution. The obvious 1836 cut-off date for the discard of the lunette sherds has caused a reexamination of this theory and sent the author on a search for the reasons for the introduction of English-made ceramics into San Antonio during the second and early third decades of the 19th century, when the population was almost entirely Hispanic. Apparently, the Mexican revolution effectively cut off shipments of supplies from Mexico to the San Antonio River settlements by about 1820 . This brought about a sudden increase in the already existent contraband trade with the United States, primarily through the port of New Orleans. A cursory study of the Bexar Archives facilitated by Benavides' (1989) Name Guide, reveals numerous accounts of arrests and confiscations in the 1820s and 1830s of San Antonio merchants for illegal operations. The center of these activities appears to have been Matagorda Bay, where numerous small, sheltered bays and inlets allowed the quiet off-loading of contraband shipments onto two-wheeled carts for the trip up the road through La Bahía (present-day Goliad) to San Antonio. The reasons for the burgeoning of this trade and the accounts in the archives of the involvement of nearly all the prominent families of San Antonio in it during this period are beyond the scope of this report but certainly deserve further research.

The 1989 field school, as is often the case with such projects, did not so much answer questions as it posed additional ones. The likelihood that the continuation of the east-west trench would become the trench in front of the palisade wall was not unexpected. Similarly, the evidence for a possible glacis to the south of the trench was interesting and not altogether unexpected, given the military training of the men who fortified the area in $\mathbf{1 8 3 5}$. It was a disappointment not to find the setting trenches for the palisade wall; some rethinking on the possible design of this end of the wall is now appropriate. The presence of an active spring in this area may have been associated with the situation, if indeed it was active at that time. Perhaps this explains why some contemporary maps of the area show an opening between the palisade wall and the barracks. As for the possibility of the trench's use as a moat, no evidence suggesting the presence of a water-filled ditch (such as silt deposits at the bottom) was found. As such an elaborate arrangement hardly seems warranted in this particular situation, the idea may have been a later elaboration suggested by the alignment of the trench.

The minor differences in size and shape of the east-west and lunette trenches are probably not of any particular importance. It seems probable that both were constructed at the same time and by the same workmen, since the east-west trench was a necessary part of the fortification of the palisade wall. The variance in fill content between the two, which had to have been filled during the same operation, is attributed to the varying distance from the gate midden, the richest source of artifacts - 
including mission-related, post-mission occupation-related, and battle-related objects since the brunt of the 1836 assault appears to have concentrated more around the gate and the southwest corner.

It was somewhat disappointing not to recover more about the construction of the lunette fortification itself. Unfortunately, the area opened up in that location was insufficient to properly interpret what was found. Ultimately, the 1989 excavations did not expose sufficient area in the vicinity of the one-story rooms built perpendicular to the low barracks. Artifacts recovered there were related more to the Army's occupation and later periods than to the early 19 th century, when these rooms were probably occupied. They were probably constructed of perishable materials, not lasting very long in comparison to the stone and adobe construction around the rest of the plaza. Additional excavations in this area could probably reveal the date of construction and use of these rooms

\section{RECOMMENDATIONS}

Judging from the results obtained by archaeological trenching in the park area and observations made during various construction activities in the plaza, the original plaza surface is 25 to $50 \mathrm{~cm}$ (or roughly 10 to 20 inches) below the present ground surface in many areas. Therefore, monitoring of any potential alterations of the plaza surface is imperative. The fill depth in the present park area protects this zone adequately, but any future plans for excavating or changing the surface elevation of this area should also consider archaeology. This is particularly important in the light of the fact that more information could be obtained within the lunette trench boundaries if sufficient area could be uncovered. The opportunity for such examination would probably come only if a major change in landscaping and land levels is planned in the future.

The only possible way to acquire accurate information concerning the construction of the palisade wall and its trench will be to conduct archaeological excavations in the area across the street from the 1989 excavations - a property now controlled by the Daughters of the Republic of Texas. Although this organization has steadfastly refused previous requests to work there, we hope that this attitude will change at some time in the future.

\section{REFERENCES CITED}

Ables, L. R.

1967 The Second Battle for the Alamo. The Southwestern Historical Quarterly $70(3)$.

Albert, A. H.

1973 Record of American Uniform and Historical Buttons With Supplement. Boyerstown Publishing Company, Boyerstown, Pennsylvania.

Albert, L. S. and K. Kent

1949 The Complete Button Book. John Edwards, Stratford, Connecticut.

Arana, L. R. and A. Manucy

1977 The Building of Castillo de San Marcos. Eastern National Park and Monument Association for Castillo de San Marcos National Monument.

Babbitt, E. B.

1849 A Letter to Major General T. S. Jessup, Quartermaster General, Washington, D.C., August 18, 1849. On file, Office of the Quartermaster General, San Antonio, National Archives, Washington, D. C.

Baines, A., editor

1961 Musical Instruments Through the Ages. Penguin Books, Baltimore, Maryland.

Barnes, M. R.

1980 Mexican Lead Glazed Earthenwares. In Spanish Colonial Frontier Research, compiled and edited by H. F. Dobyns: Center for Anthropological Studies, Spanish Borderlands Research 1, Albuquerque. 
Barnes, M. R. and R. V. May

1972 Mexican Majolica in Northern New Spain. Pacific Coast Archaeological Society Occasional Paper 2, Cosa Mesta, California.

Bedford, J.

1965 Old English Luster Ware. Walker and Co., New York.

Bemrose, G.

1952 Nineteenth Century English Pottery and Porcelain. Pittman Publishing Co., New York.

Benavides, A., Jr., compiler and editor

1989 The Bexar Archives (1717-1836), A Name Guide. University of Texas Press, Austin, for The University of Texas Institute of Texan Cultures at San Antonio.

Bexar County, Texas

Deed Records (DR). Originals and microfilm located in the Bexar County Courthouse, San Antonio, Texas.

Black, A.

1987 An Overview of Selected Ceramics from Excavations at the Fanthorpe Inn. In Archeological Investigations at Fanthorpe Inn State Historic Site, Grimes City, Texas, by D. Ing and J. Hart. Texas Parks and Wildlife Department, Historic Sites and Restoration Branch, Austin.

Bolton, H. E.

1970 Texas in the Middle Eighteenth Century. University of California Publications in History 3. Original printing, 1915. Reprinted by University of Texas Press, Austin, Texas.
Bonath, S.

1979 An Evaluation of the Mean Ceramic Date Formula as Applied to South's Majolica Model. Historical Archaeology 12:82-92.

Boyd, E.

1974 Personal communication to Kathleen Gilmore.

Brantley, W. F.

1975 A Collector's Guide to Ball Jars. Rosemary Humbert Martin, Muncie, Indiana.

Brown, M. and S. G. McConnell

1987 Transfer-Printed Whiteware from the La Villita Earthworks (41 BX 677). Unpublished manuscript on file, Center for Archaeological Research, The University of Texas at San Antonio.

Burnett, R. E.

1974 Olive Jar. In Mission Rosario: Archeological Investigations, 1973 by K. Gilmore. Texas Parks and Wildlife Department, Parks Division, Archeological Report 14, Part 1.

Campbell, T. N.

1962 Origins of Pottery Types from the Coastal Bend Region of Texas. Bulletin of the Texas Archeological Society 32:331-336.

1985 Rancho de las Cabras and the "Cabras Indians" of Southern Texas: Correction of Minor Historical Errors. In Archaeological Survey and Testing at Rancho de las Cabras, 41 WN 30, Wilson County, Texas, Fifth Season, by A. J. Taylor and A. A. Fox: Center for Archaeological Research, The University of Texas at San Antonio, Archaeoogical Survey Report 144. 
Campbell, T. N. and T. J. Campbell

1985 Indian Groups Associated with Spanish Missions of the San Antonio Missions National Historical Park. Center for Archaeological Research, The University of Texas at San Antonio, Special Report 16.

Castañeda, C. E.

1928 The Mexican Side of the Texas Revolution (1836) by the Chief Mexican Participants, General Antonio Lopez de Santa-Anna, D. Ramon Martinez Caro (Secretary to Santa-Anna), General Vicente Filisola, General José Urrea, General José Maria Tornel (Secretary of War). Translated with notes by Carlos E. Castañeda. Reprinted in 1956 by Turner Publishing Company, Dallas.

1942 The Mission Era, The End of the Spanish Regime, 1780-1810. Our Catholic Heritage in Texas V. Von Boeckmann-Jones Company, Austin.

1950 Transition Period, The Fight for Freedom. Our Catholic Heritage in Texas VI. Von Boeckmann-Jones Company, Austin.

Caywood, L. R.

1950 Hispanic Pottery as a Guide in Historical Studies. In For the Dean ed. by E. K. Reed: Hohokam Museum Association and Southwestern Monuments Association, Santa Fe.

Cervantes, G. L

1974 Porcelana Europea en Mexico. Boletín, Instituto Nacional de Antropologia e Historia 9, Epoca II.

Chabot, F. C.

1941 The Alamo: Mission, Fortress and Shrine. Privately published. San Antonio.
Charlton, T. H. and R. R. Katz

1979 Tonalá Bruñida Ware. Archaeology 32(1):45-53.

City Public Service

1976 How Did We Get Where We Are Today? Unpublished manuscript on file, Daughters of the Republic of Texas Research Library, The Alamo, San Antonio.

Cooley, E. B.

1900 A Retrospect of San Antonio, The Texas Historical Assoication Quarterly IV:54-56.

Corbin, J. E., T. C. Alex and A. Kalina

1980 Mission Dolores de los Ais: Archaeological Investigations of an Early Spanish Colonial Mission, San Augustine County, Texas. Stephen F. Austin State University and Texas Antiquities Committee, Stephen F. Austin Papers in Anthropology 2, Texas Antiquities Permit Series 3.

Corner, W.

1890 San Antonio de Bexar: A Guide and History. Bainbridge and Corner, San Antonio, Texas.

Coysh, A. W.

1970 Blue and White Transfer Ware, 1780-1840. David and Charles Newton Abbot, Devon, England.

Crabtree, D. E

1972 An Introduction to Flintworking. Occasional Papers of the Idaho State University Museum 28. Pocatello.

1982 An Introduction to Flintworking. Second edition. Occasional Papers of the Idaho State University 28, Pocatello. 
Davis, E. M. and J. Corbin

1967 Archeological Investigations at Washington-on-the-Brazos State Park in 1966. State Building Commission, Archeological Program Report 5, Austin.

Deagan, K. A.

1974 Sex, Status and Role in the Mestizaje of Spanish Colonial Florida. Ph.D. dissertation, University of Florida, Gainesville.

Deetz, J.

1967 Invitation to Archaeology. The Natural History Press, Garden City, New York.

Diaz, M.

1966 Tonalá: Conservatism, Responsibility and Authority in a Mexican Town. University of California Press, Berkeley.

DiPeso, C. C.

1951 The Babocomari Village Site on the Babocomari River, Southeastern Arizona. The Amerind Foundation, Inc. 5, Dragoon, Arizona.

Eaton, J. D.

1980 Excavations at the Alamo Shrine (Mission San Antonio de Valero). Center for Archaeological Research, The University of Texas at San Antonio, Special Report 10.

Encyclopaedia Britannica

1946 Electricity. Encyclopaedia Britannica, A New Survey of Universal Knowledge 14:182-216. Encyclopaedia Britannica, Inc., Chicago.

1946 Harmonica. Encyclopaedia Britannica, A New Survey of Universal Knowledge 11:199. Encyclopaedia Britannica, Inc., Chicago.
1954 Lighting and Artificial Illumination. Encyclopaedia Britannica, $A$ New Survey of Universal Knowledge 14:105-114. Encyclopaedia Britannica, Inc., Chicago.

Espejel, C.

1975 Mexican Folk Ceramics. Editorial Blume.

Fike, R. E.

1987 The Bottle Book. A Comprehensive Guide to Historic, Embossed Medicine Bottles. Peregrin Smith Books, Salt Lake City.

Filisola, V.

1849 Memorias para la Historia de la Guerra de Tejas, por el Sr. General de Division y Actual Presidente del Supremo Tribunal de Guerra y Marina de la Republica, Segunda Parte. Tipografia de R.Rafael, Calle de Cadena Num. 13, Mexico.

Folan, W. J., I. W. Cox, A. A. Fox, and G. M. Hinojosa

1986 Laredo, Texas: A Gateway Community on the Texas Borderlands. Archaeological and Historical Investigations for the Laredo City Toll Plaza (41 WB 36, 37 and 38). Center for Archaeological Research, The University of Texas at San Antonio, Archaeological Surevey Report 116.

Ford, J. S.

1875 A Mexican Sergeant's Recollections of the Alamo and San Jacinto. By Francisco Becerra as told by John S. Ford in 1875. Jenkins Publishing Company, Austin.

1895 Origin and Fall of the Alamo. Johnson Brothers Printing Company, San Antonio. 
Foshee, R.

1986 Mocha Ware: The Pottery for Everyman. Country Living 19(4).

Fox, A. A.

1974 Lead Glazed Wares. In Mission Rosario, Archeological Investigations 1973 by K. Gilmore:55-59. Texas Parks and Wildlife Department, Parks Division, Historic Sites and Restoration Branch, Archeological Report 14, Part 1.

1977a The Archaeology and History of the Spanish Governor's Palace Park. Centerfor Archaeological Research, The University of Texas at San Antonio, Archaeological Survey Report 31.

1977b Archaeological Observations at Alamo Plaza. Report on file, Center for Archaeological Research, The University of Texas at San Antonio.

1984 A Study of Five Historic Cemeteries at Choke Canyon Reservoir, Live Oak and McMullen Counties, Texas. Center for Archaeological Research, The University of Texas at San Antonio, Choke Canyon Series 9.

1986 Ceramics. In La Villita Earthworks (41 BX 677): San Antonio, Texas. A Preliminary Report of Investigations of Mexican Siege Works at the Battle of the Alamo, assembled by J. H. Labadie:107-127. Center for Archaeological Research, The University of Texas at San Antonio, Archaeological Survey Report 159.

1988a Archaeological Investigations at Mission Concepción, Fall of 1986. Centerfor Archaeological Research, The University of Texas at San Antonio, Archaeological Survey Report 172.

1988b Historic Ceramics. Unpublished paper presented at a workshop on The Ceramics of Texas, Witte Museum, San Antonio.
1990 Mission Builders: Traces of Texas Archaeology. Paper given at symposium, The Spanish Missionary Heritage of the United States, November 8-10, 1990, in San Antonio.

Fox, A. A., F. A. Bass, Jr., and T. R. Hester

1976 The Archaeology and History of Alamo Plaza. Center for Archaeological Research, The University of Texas at San Antonio, Archaeological Survey Report 16.

Fox, D. E.

1979 The Lithic Artifacts of Indians at the Spanish Colonial Missions, San Antonio, Texas. Center for Archaeological Research, The University of Texas at San Antonio, Special Report 8.

1983 Traces of Texas History: Archeological Evidence of the Past 450 Years. Coronal Publishing Company, San Antonio.

Fox, D. E., R. J. Mallouf, N. O'Malley, and W. M. Sorrow

1974 Archaeological Resources of the Proposed Cuero I Reservoir, DeWitt and Gonzales Counties, Texas. Texas Historical Commission and Texas Water Development Board, Archeological Survey Report 12, Austin.

Freeman, M. D.

1972 Public Markets in San Antonio. San Antonio Development Agency. Copy on file, Daughters of the Republic of Texas Research Library, The Alamo. San Antonio.

Freeman, W. G., Lt. Col.

1853 Report of Inspection of Quartermaster Depot at the Alamo, Office of the Quartermaster General, San Antonio. National Archives, File Box No.1, Washington, D.C. 
Fretelliere, H. T.

1912 San Antonio de Bexar, Half a Century Ago. Texas Magazine V(5), March.

Garrett, J. K.

1968 Green Flag Over Texas: The Last Years of Spain in Texas. The Pemberton Press, Austin, Texas.

Gates, W. C., Jr. and D. E. Ormerod

1982 The East Liverpool Pottery District: Identification of Manufacturers and Marks. Historical Archaeology 16(1-2).

Gerald, R. E.

1968 Spanish Presidios of the Late Eighteenth Century in Northern New Spain. Museum of New Mexico Research Records 7. Museum of New Mexico Press, Santa Fe.

Gilmore, K. K.

1969 The San Xavier Missions: A Study in Historical Identification. State Building Commission, Archeological Program Report 16, Austin.

1973 The Keeran Site, the Probable Site of La Salle's Fort St. Louis in Texas. Texas Historical Commission, Office of the State Archeologist Report 24, Austin.

1974 Mission Rosario: Archeological Investigations, 1973. Texas Parks and Wildlife Department, Parks Division, Historic Sites and Restoration Branch, Archeological Report 14, Part 1.

1975 Mission Rosario: Archeological Investigations, 1974. Texas Parks and Wildlife Department, Parks Division, Historic Sites and Restoration Branch, Archeological Report 14, Part 2.

1986 French and Indian Interaction at an Eighteenth Century Frontier Post: The Roseborough Site, Bowie City, Texas. Institute of Applied Sciences, North Texas State University Contributions in Archaeology 3.
Giraud, F.

1849 Plat and Field Notes. City Survey Book:114-115, Bexar County Archives, San Antonio.

Godden, G. A.

1963 British Pottery and Porcelain 1780-1850. A. S. Barnes and Co., Inc., New Jersey.

1964 Encyclopedia of British Pottery and Porcelain Marks. Bonanza Books, New York.

Goggin, J. M.

1964 The Spanish Olive Jar. In Indian and Spanish Selected Writings, University of Miami Press, Coral Gables.

Greer, G.

1981 American Stonewares, the Art and Craft of the Utility Potter. Schiffer Publishing Ltd., Exton, Pennsylvania.

Guerlac, H.

1986 Vauban: The Impact of Science on War, in Makers of Modern Strategy from Machiavelli; to the Nuclear Age, ed. by Peter Paret. Princeton University Press, pp. 64-90.

Gunn, J., A. A. Fox, H. Uecker, and I. W. Cox

1989 Alamo Excavation 1989 - South Defense. Manuscript on file, Center for Archaeological Research, The University of Texas at San Antonio.

Habig, M. A.

1968 The Alamo Chain of Missions: A History of San Antonio's Five Old Missions. Franciscan Herald Press, Chicago.

Harris, R. K. and I. M. Harris

1967 Trade Beads, Projectile Points, and Knives. In $A$ Pilot Study of Wichita Indian Archeology and Ethnohistory, assembled by R. E. Bell, E. B. Jelks, and W. W. Newcomb:129-162.Southern 
Methodist University, Dallas. Report to the National Science Foundation.

Hays, R. R. and E. B. Jelks

1966 Archaeological Exploration at Fort Lancaster, 1966. State Building Commission Archeological Program Report 4, Austin.

Haythornthwaite, P. J.

1979 Weapons and Equipment of the Napoleonic Wars. Blandford Press Ltd., Poole, Dorset, United Kingdom.

Hemion, R. H.

1978 Light in San Antonio. Unpublished manuscript on file, Center for Archaeological Research, The University of Texas at San Antonio.

Hester, T. R.

1975 Material Culture at San Bernardo: Preliminary Comments. In Archaeological and Ethnohistory of the Gateway Area, Middle Rio Grande of Texas:23-26. Report submitted to the National Endowment for the Humanities by The University of Texas at San Antonio.

1977a The Lithic Technology of Mission Indians in Texas and Northeastern Mexico. Lithic Technology IV(1-2).

1977b Material Culture at Missions San Juan Bautista and San Bernardo. In The Archaeology and Ethnohistory of the Gateway Area: Middle Rio Grande of Texas, Final Report to the National Endowment for the Humanities, assembled by R. E. W. Adams: by the University of Texas at San Antonio.

1980 Digging into South Texas Prehistory: $A$ Guide for Amateur Archaeologists. Corona Publishing Company, San Antonio.
Hudgins, J. D.

1986 A Historic Indian Site in Wharton County, Texas. Bulletin of the Texas Archeological Society 55: Austin, Texas.

Hughes, B. and T. Hughes

1868 The Collectors' Encyclopedia of English Ceramics. Abbey Library, London.

Huson, $\mathrm{H}$.

1949 Dr. J. H. Barnard Journal. Goliad Bicentennial Edition.

Hussey, R. D.

1963 Colonial Economic Life. In Colonial Hispanic America, edited by C. Wilgus: Russell and Russell, New York.

Ing, D. and J. Hart

1987 Archeological Investigations at Fanthorpe Inn State Historic Site, Grimes City, Texas. Texas Parks and Wildlife Department, Parks Division, Historic Sites and Restoration Branch, Austin.

Israel, F. L.

19681897 Sears Roebuck Catalogue. Chelsea House, New York.

Ivey, J. E.

1983 Archaeological Testing at Rancho de las Cabras, Wilson County, Texas. Second Season. Center for Archaeological Research, The University of Texas at San Antonio, Archaeological Survey Report 121.

1978 Archaeological Investigations at the Gresser House (41 BX 369), San Antonio, Texas. Center for Archaeological Research, The University of Texas at San Antonio, Archaeological Survey Report 60.

n.d. Mission to Fortress: The Defenses of the Alamo. Manuscript on file at the Center for Archaeological Research, 
The University of Texas at San Antonio.

Ivey, J. E. and A. A. Fox

1981 Archaeological Survey and Testing at Rancho de las Cabras, Wilson County, Texas. Center for Archaeological Research, The University of Texas at San Antonio, Archaeological Survey Report 104.

Jelks, E. B., editor

1967 The Gilbert Site. Bulletin of the Texas Archeological Society 37 (entire volume).

Jenkins, J. H.

1973 The Papers of the Texas Revolution 1835-1836. Volume 4. Presidial Press, Austin.

Johnson, F. W.

1914 A History of Texas and Texans. Volume III. The American Historical Society, Chicago and New York.

Jones, C. J., J. W. Kunert, and P. M. Foster

1979 Analysis of Debitage Material Recovered from 1979 Summer Field School Excavation of 41 BX 271 (Granberg II). Unpublished research paper on file, Center for Archaeological Research, Department of Anthropology, The University of Texas at San Antonio.

Joukowsky, M.

1980 A Complete Manual of Field Archeology: Tools and Techniques of Field Work for Archaeologists. Prentice-Hall, Englewood Cliffs, New Jersey.

Kane, B.

1947 Gaudy Dutch China Wares. Hobbies September.
Katz, R. R.

1977 The Potters and Pottery of Tonalá, Jalisco, Mexico: A Study in Aesthetic Anthropology. Ph.D. dissertation, Columbia University.

Keeley, L. H. and D. Cahen

1989 Early Neolithic Forts and Villages of NE Belgium. A Preliminary Report. Journal of Field Archaeology 16(2). Boston University.

Kelly, T. C.

1975 Flake Analysis 41 BX 271. Unpublished research paper on file, Center for Archaeological Research, The University of Texas at San Antonio.

Kendrick, G.

1966 The Antique Bottle Collector. Edwards Brothers, Ann Arbor, Michigan.

1967 Bottle Fragments Betray Age of Historical Sites. El Palacio 74(2):19-24.

Kidder, A. V.

1924 An Introduction to the Study of Southwestern Archaeology with a Preliminary Account of the Excavations at Pecos. Fourth printing, revised, Yale University Press, New Haven.

Labadie, J. $\mathbf{H}$.

1983 Lithic Artifact Analysis for the 1980 and 1981 Seasons at Rancho de las Cabras. In Archaeological Testing at Rancho de las Cabras, 41 WN 39, Wilson County, Texas, Second Season, by J. E. Ivey: 47-67. Center for Archaeological Research, The University of Texas at San Antonio, Archaeological Survey Report 121.

Labadie, J. H., assembler

1986 La Villita Earthworks: A Preliminary Report of Investigations of Mexican 
Siege Works at the Battle of the Alamo, San Antonio, Texas. Center for Archaeological Research, The University of Texas at San Antonio, Archaeological Survey Report 159.

Lister, F. C. and R. H. Lister

1975 Non-Indian Ceramics from the Mexico City Subway. El Palacio 81.

Lohse, J. C.

1991 San Antonio de Valero Mission Lithics. Manuscript on file at the Balcones Research Center, Texas Archeological Research Laboratory, The University of Texas at Austin.

Lord, W. L.

1961 A Time to Stand. Harper \& Brothers, New York.

Lorrain, D.

1968 An Archaeologist's Guide to Nineteenth Century American Glass. Historical Archaeology 2:35-44.

Luckiesh, M.

1940 Torch of Civilization, the Story of Man's Conquest of Darkness. G. P. Putnam's Sons, New York.

Mallouf, R. J.

1976 Archeological Investigation at Proposed Big Pine Lake, 1974-1975, Lamar and Red River Counties, Texas. Texas Historical Commission, Archeological Survey Report 18.

McKenzie, C.

1989 Guanajuato Majolica. Manuscript on file, Center for Archaeological Research, The University of Texas at San Antonio.

Moir, R.

1982 Sheet Refuse: An Indicator of Past Lifeways. In Settlement of the Prairie
Margin: Archaeology of the Richland Creek Reservoir, Navarro and Freestone Counties, Texas, 1980-1981. A Research Synopsis. Archaeology Research Program, Department of Anthropology, Southern Methodist University, Archaeological Monographs 1.

n.d. Edgeware. Manuscript on file, Center for Archaeological Research, The University of Texas at San Antonio.

Moriarty, J. R. III and R. S. D. Broms

1971 The Antiquity and Inferred Use of Stone Discoidals in the Southwest. Anthropological Journal of Canada 9(1):16-36.

Mounger, M. A.

1959 Mission Espiritu Santo of Coastal Texas: An Example of Historic Site Archeology. Masters thesis, University of Texas at Austin.

Muller, J.

1968 A Treatise Containing the Elementary Part of Fortification, Regular and Irregular. Originally printed in 1746 for J. Nourse at the Lamb, opposite Katherine-Street, in the Strand. Reprinted in 1968 by Museum Restoration Service, Ottawa, Ontario, Canada.

Munsell Color Company

1975 Munsell Soil Color Charts. Baltimore, Maryland.

Munsey, C.

1970 The Illustrated Guide to Collecting Bottles. Hawthorn Books, Inc., New York.

Neely, J. A.

1989 Lectures on Ceramic Technology. University of Texas at Austin. 
Nevin, D.

1975 The Old West: The Texans. Time-Life Books, Alexandria, Virginia.

Newcomb, P.

1926 The Alamo City. Standard Printing Company Press, San Antonio.

Nixon, P. I., M.D.

1936 A Century of Medicine in San Antonio. Privately published, San Antonio.

Noel Hume, I.

1970 A Guide to Artifacts of Colonial America. Knopf, New York.

Perry, C.

1975 With Santa Anna in Texas, A Personal Narrative of the Revolution by Jose Enrique de la Peña. Texas A\&M University Press, College Station.

Potter, Capt. R. M.

1933 The Fall of the Alamo. Old South Leaflets 130 . Privately printed. John Peace Library Special Collections Department, The University of Texas at San Antonio.

Ramsay, J.

1976 American Potters and Pottery. Ars Ceramica, Ltd., Ann Arbor, Michigan.

Ramsdell, C.

1959 San Antonio, A Historical and Pictorial Guide. University of Texas Press, Austin.

Rawn, V. M.

1977 Appendix I: Analysis of the Bone Material. In An Archeological Investigation of Mission Concepción, San Antonio, Texas, by D. Scurlock and D. E. Fox:143-152. Texas Historical Commission, Office of the State Archeologist Report 28.
Rice, $\mathbf{P}$.

1987 Pottery Analysis: A Source Book. The University of Chicago Press, Chicago.

Robacker, E. and A. Robacker

n.d. Spatterware and Spongeware. A. S. Barnes and Company, New York.

Robichaux, H.R.

19891989 Alamo Plaza Excavations. A Draft Report on Planter Holes and Garden Soil. Manuscript on file, Center for Archaeological Research, The University of Texas at San Antonio.

Rodriguez, J. M.

1961 The Rodriguez Memoirs of Early Texas. Passing Show Publishing Company, San Antonio. Reprinted by Standard Printing Company, San Antonio.

Salinas, M.

1990 Indians of the Rio Grande Delta: Their Role in the History of Southern Texas and Northeastern Mexico. University of Texas Press, Austin.

San Antonio Light

1859 Untitled article, February 1.

Sánchez Lamego, M. A.

1968 The Siege and Taking of the Alamo. Translated by Consuelo Velasco. Press of the Territorian, Santa Fe.

Sánchez-Navarro, C., editor

1938 La Guerra de Tejas, Memorias de un Soldado. Editorial Polis, Mejico.

Santos, R. G.

1968 Santa Anna's Campaign Against Texas,1835-1836. Texian Press, Waco, Texas. 
Schoelwer, S. P.

1988 The Artist's Alamo: A Reappraisal of Pictorial Evidence, 1836-1850. The Southwestern Historical Quarterly 91(4).

Schoelwer, S. P. with T. W. Gläser

1985 Alamo Images, Changing Perceptions of a Texas Experience. The DeGolyer Library Publications Series 3. Southern Methodist University Press, Dallas.

Schuetz, M. K.

1966 Historic Background of the Mission San Antonio de Valero. State Building Commission Archeological Program, Report 1.

1969 Description of the Artifacts and Ethno-History of the Coahuiltecan Indians. The History and Archeology of Mission San Juan Capistrano, San Antonio, Texas, Volume II. State Building Commission Archeological Program Report 11.

1970 Excavation of a Section of the Acequia Madre in Bexar County, Texas, and Archeological Investigations at Mission San José in April, 1968. Texas Historical Survey Committee, Archeological Report 19.

Scurlock, D. and D. E. Fox

1977 An Archeological Investigation of Mission Concepción, San Antonio, Texas. Office of the State Archeologist, Texas Historical Commission, Archeological Report 28.

Shafer, H. J.

1969 Archeological Investigations in the Robert Lee Reservoir Basin, West Central Texas. Papers of the Texas Archeological Salvage Project, The University of Texas at Austin 17.

1989 Origins of Prehistoric Texas Pottery. Paper presented at Council of Texas Archeologists Symposium: Late
Prehistoric and Early Historic Interaction in Texas, Austin.

Simmons, M. and F. Turley

1980 Southwestern Colonial Ironwork, the Spanish Blacksmithing Tradition from Texas to California. Museum of New Mexico Press, Santa Fe.

Smith, C.

1981 Country Antiques and Collectibles. Oxmoor House, Inc., Birmingham, Alabama.

Smith, H. R.

1966 History of Alamo Plaza from its Beginning to the Present. Masters thesis, Trinity University, San Antonio.

South, S.

1964 Analysis of Buttons from Brunswick Town and Fort Fisher. The Florida Anthropologist XVII(2):113-133.

Suhm, D. A. and E. B. Jelks

1962 Handbook of Texas Archeology: Type Descriptions. Texas Archeological Society and Texas Memorial Museum, Special Publication 1, Austin.

Sussman, L.

1979 Spode/Copeland Transfer-Printed Patterns Found at 20 Hudson's Bay Company Sites. Canadian Historic Sites: Occasional Papers in Archaeology and History 22. National Historic Parks and Sites Branch, Parks Canada, Ottawa.

Taylor, A. J. and A. A. Fox

1985 Archaeological Survey and Testing at Rancho de las Cabras, 41 WN 30. Wilson County, Texas, Fifth Season. Center for Archaeological Research, The University of Texas at San Antonio, Archaeological Survey Report 144. 
Thomas, W. S.

1970 Fort Davis and the Texas Frontier. Paintings by Captain Arthur T. Lee, Eighth U.S. Infantry. Texas A\&M University Press, College Station.

Towner, D.

1978 Creamware. Faber and Faber, Boston.

Tunnell, C.

1966 A Description of Enameled Earthenware from an Archeological Excavation at Mission San Antonio de Valero (The Alamo). State Building Commission Archeological Program Report 2.

Tunnell, C. and R. Ambler

1967 Archeological Excavations at Presidio San Agustín de Ahumada. State Building Commission Archeological Program Report 6.

Tunnell, C. and W. W. Newcomb, Jr.

1969 A Lipan Apache Mission, San Lorenzo de la Santa Cruz, 1762-1771. Bulletin of the Texas Memorial Museum 14, Austin.

Turner, S. E. and T. R. Hester

1985 A Field Guide to Stone Artifacts of Texas Indians. Texas Monthly Press, Austin.

Tyler, J. D.

1974 Technological Development: Agent of Change in Style and Form of Domestic Iron Castings. Technological Innovation in the Decorative Arts, 19th Annual Winterthur Conference Report for 1973: 141-163.

Uecker, H. G.

1979 Analysis of Selected Debitage from 41 BX 228. Center for Archaeological Research, The University of Texas at San Antonio, Manuscript Series 13.
1991 An Analysis of Lithic Artifacts from the Phase II Investigations at Site 41 VV 1251 in: Archaeological Testing for a Proposed Landfill Expansion (Phase II), City of Del Rio, Val Verde County, Texas. Center for Archaeological Research, The University of Texas at San Antonio. Archaeological Survey Report 197.

Van Rensselaer, S.

1966 Banded Creamware. Antiques Magazine XC(3):337-340.

Viel, E. L.

1861 Hand-book for Active Service; Containing Practical Instructions in Campaign Duties for the Use of Volunteers. Original printing by D. Van Nostrand. Reprinted in 1968 by Greenwood Press, Publishers, New York.

Wallace, E. and D.M. Vigness, editors

1962 Documents of Texas History. The Steck Company, Austin.

Wheeler, J. B.

1898 The Elements of Fortification for the Use of the Cadets of the United States Military Academy at West Point, N.Y. D. Van Nostrand Company, New York.

Williams, A.

1931 A Critical Study of the Siege of the Alamo and of the Personnel of its Defendants. Ph.D. dissertation manuscript submitted to the faculty of the graduate school, The University of Texas at Austin. Copy on file at the Daughters of the Republic ofTexas Research Library, San Antoio.

Wilson, R. L.

1966 Tobacco Pipes from Fort Union, New Mexico. El Palacio 73(1):32-40. 
Woolsey, W., translator

1987 Memoirs for the History of the War in Texas, Volume II. Translated from the original 1849 Spanish version authored by Don Vincente Filisola. Eakin Press, Austin.

Word, J. H. and A. A. Fox

1975 The Cogdell Burial in Floyd County, Texas. Bulletin of the Texas Archeological Society 46:1-63.
Wyckoff, M. A.

1984 United States Military Buttons of the Land Services 1787-1902, A Guide and Classificatory System. McLean County Historical Society, Bloomington, Illinois.

Yoakum, $\mathbf{H}$.

1855 History of Texas from its First Settlement in 1685 to its Annexation to the United States in 1846. Two volumes. Redfield, New Jersey. 
